\title{
Protein clearance strategies for disease intervention
}

\author{
Franziska Hommen ${ }^{1}$ Saygın Bilican ${ }^{1} \cdot$ David Vilchez $^{1,2,3}$
}

Received: 18 June 2021 / Accepted: 10 October 2021 / Published online: 23 October 2021

(c) The Author(s) 2021

\begin{abstract}
Protein homeostasis, or proteostasis, is essential for cell function and viability. Unwanted, damaged, misfolded and aggregated proteins are degraded by the ubiquitin-proteasome system (UPS) and the autophagy-lysosome pathway. Growing evidence indicates that alterations in these major proteolytic mechanisms lead to a demise in proteostasis, contributing to the onset and development of distinct diseases. Indeed, dysregulation of the UPS or autophagy is linked to several neurodegenerative, infectious and inflammatory disorders as well as cancer. Thus, modulation of protein clearance pathways is a promising approach for therapeutics. In this review, we discuss recent findings and open questions on how targeting proteolytic mechanisms could be applied for disease intervention.
\end{abstract}

Keywords Proteostasis · Proteasome · Autophagy $\cdot$ Alzheimer's disease $\cdot$ Huntington's disease $\cdot$ Parkinson's disease $\cdot$ Amyotrophic lateral sclerosis $\cdot$ Aging $\cdot$ Cancer

\section{Introduction}

The proteome of a mammalian cell contains thousands of distinct proteins (Jayaraj et al. 2020). The intracellular levels of individual proteins are adjusted to the particular needs and status of every single cell in the organism (Jayaraj et al. 2020). Moreover, numerous proteins are prone to misfolding and aggregation, leading to cell malfunction and death. Thus, maintenance of protein homeostasis (proteostasis) is essential for cell function and survival (Fig. 1). As such, cellular integrity relies on proteolytic systems that not only maintain the proper concentration of regulatory and structural proteins, but also scavenge damaged and misfolded proteins (Saez and Vilchez, 2014; Sha et al. 2018; Vilchez

Franziska Hommen and Saygın Bilican contributed equally to this work.

David Vilchez

dvilchez@uni-koeln.de

1 Cologne Excellence Cluster for Cellular Stress Responses in Aging-Associated Diseases (CECAD), University of Cologne, Joseph Stelzmann Strasse 26, 50931 Cologne, Germany

2 Center for Molecular Medicine Cologne (CMMC), University of Cologne, Cologne, Germany

3 Faculty of Medicine, University Hospital Cologne, Cologne, Germany et al. 2014). The evolutionary conserved ubiquitin-proteasome system (UPS) and autophagy-lysosome pathway are the two major protein clearance mechanisms in eukaryotes. However, conditions such as cellular stress, metabolic alterations, pathogens, environmental changes, disease-related mutations and aging can influence proteolytic systems (Hipp et al. 2019; Vilchez et al. 2014).

Deficits in protein folding and clearance mechanisms are linked to multiple disorders that involve protein aggregation, i.e., proteinopathies. The link is more compelling in neurodegenerative disorders such as Alzheimer's, Huntington's, Parkinson's and amyotrophic lateral sclerosis (ALS). Although the proteins involved in these diseases are different, they have in common the accumulation of pathological protein inclusions in neurons. In addition, these neurodegenerative diseases share similar late temporal emergence patterns. Typically, familial mutation-linked neurodegeneration emerges during the fifth decade of life, whereas the onset of sporadic neurodegenerative disease usually occurs during the seventh decade or even later (Cohen and Dillin 2008). For instance, ALS is rare before the age of 40 years, but its incidence increases exponentially thereafter with a peak at 70-79 years of age (Ingre et al. 2015). With age, post-mitotic cells such as neurons lose extensive control of the proteostasis equilibrium, including deficits in protein degradation machineries (Vilchez et al. 2014). Loss of proteostasis is a hallmark of aging, further strengthening a role of proteolytic deficits in the 


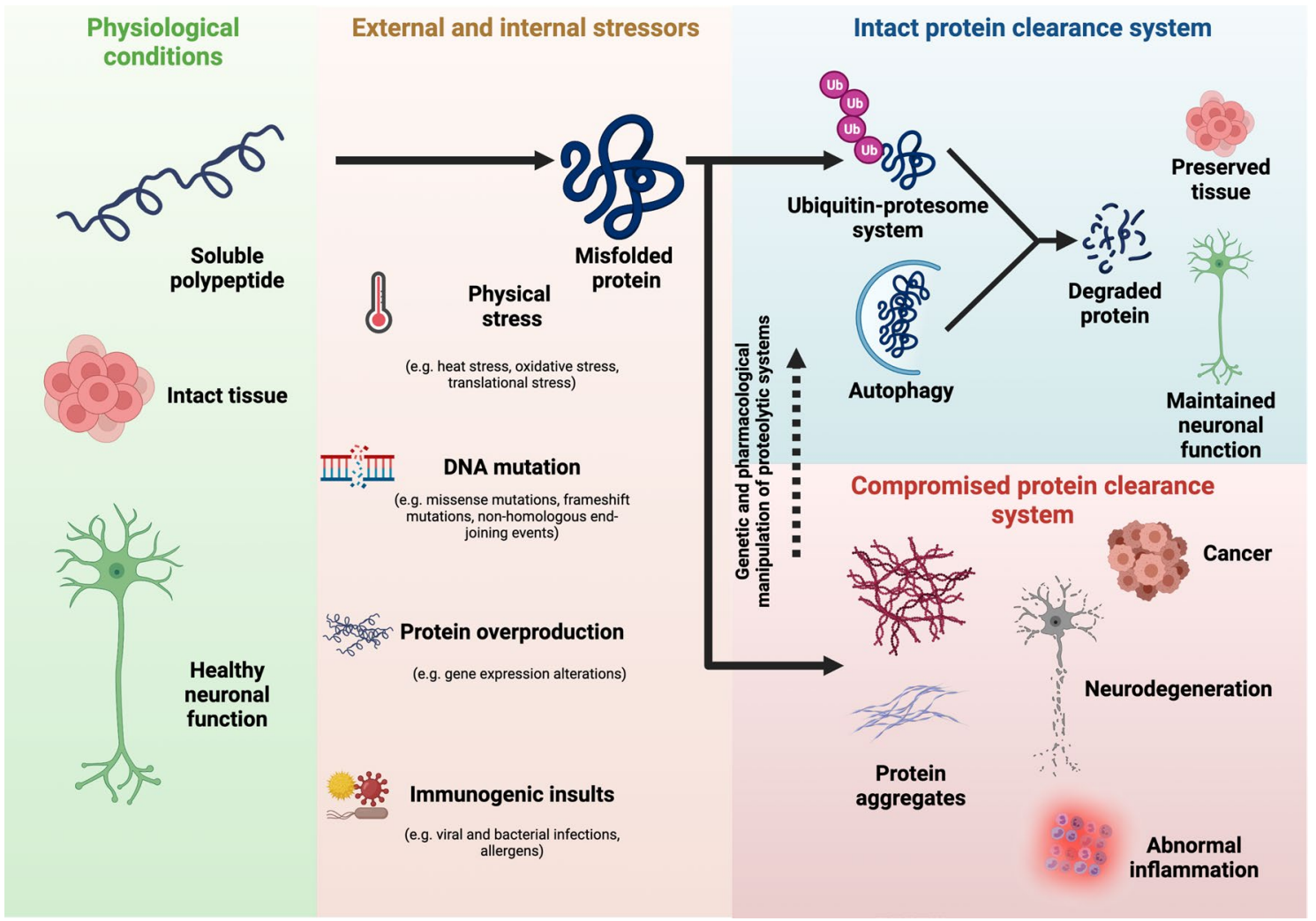

Fig. 1 Protein clearance mechanisms in health and disease. Misfolded proteins that ensue from external and internal stressors are degraded through two major protein clearance pathways, i.e., the ubiquitin-proteasome system (UPS) and the autophagy-lysosome pathway. Dys- function of these pathways contribute to the accumulation of protein aggregates, a hallmark of disorders such as Alzheimer's disease, Huntington's disease, Parkinson's disease and amyotrophic lateral sclerosis

is catalyzed by a sequential cascade of three enzymatic reactions, starting with $\mathrm{Ub}$ activation by the Ub-activating enzyme E1 (UBA1) in an ATP-dependent reaction (Lambert-Smith et al. 2020). Adenylation of Gly76 at the C-terminus of $\mathrm{Ub}$ is followed by a thioester bond formation between UBA1 and Ub (Lambert-Smith et al. 2020). Thereafter, Ub-conjugating enzymes (E2s) are recruited by the C-terminal ubiquitin-fold domain of UBA1 where Ub is transferred to the E2 enzyme (Hershko and Ciechanover 1998). The resulting thioester intermediate dissociates from UBA1 and, together with the target protein, binds to a specific E3 ubiquitin ligase (Hershko and Ciechanover 1998). Then, E3 ligases catalyze the covalent attachment of $\mathrm{Ub}$ to the target protein. In humans, there are more than $600 \mathrm{E} 3$ enzymes which can be distinguished into two main classes, i.e., RING-type and HECT-type E3s (Plechanovová et al. 2012). Whereas E3 ligases mark proteins with $\mathrm{Ub}$, deubiquitinating enzymes (DUBs) can reverse this process (Wilkinson 2000). To date, 102 DUBs have been reported in humans (Clague et al. 2019; Pinto-Fernández et al. 2019). Thus, the activities of E3 ligases and DUBs are tightly balanced to maintain intracellular proteostasis and cellular function (Bax et al. 2019; Choi and Baek 2018). In these lines, the landscape of E3 and DUB enzymes undergo a profound rewiring during 


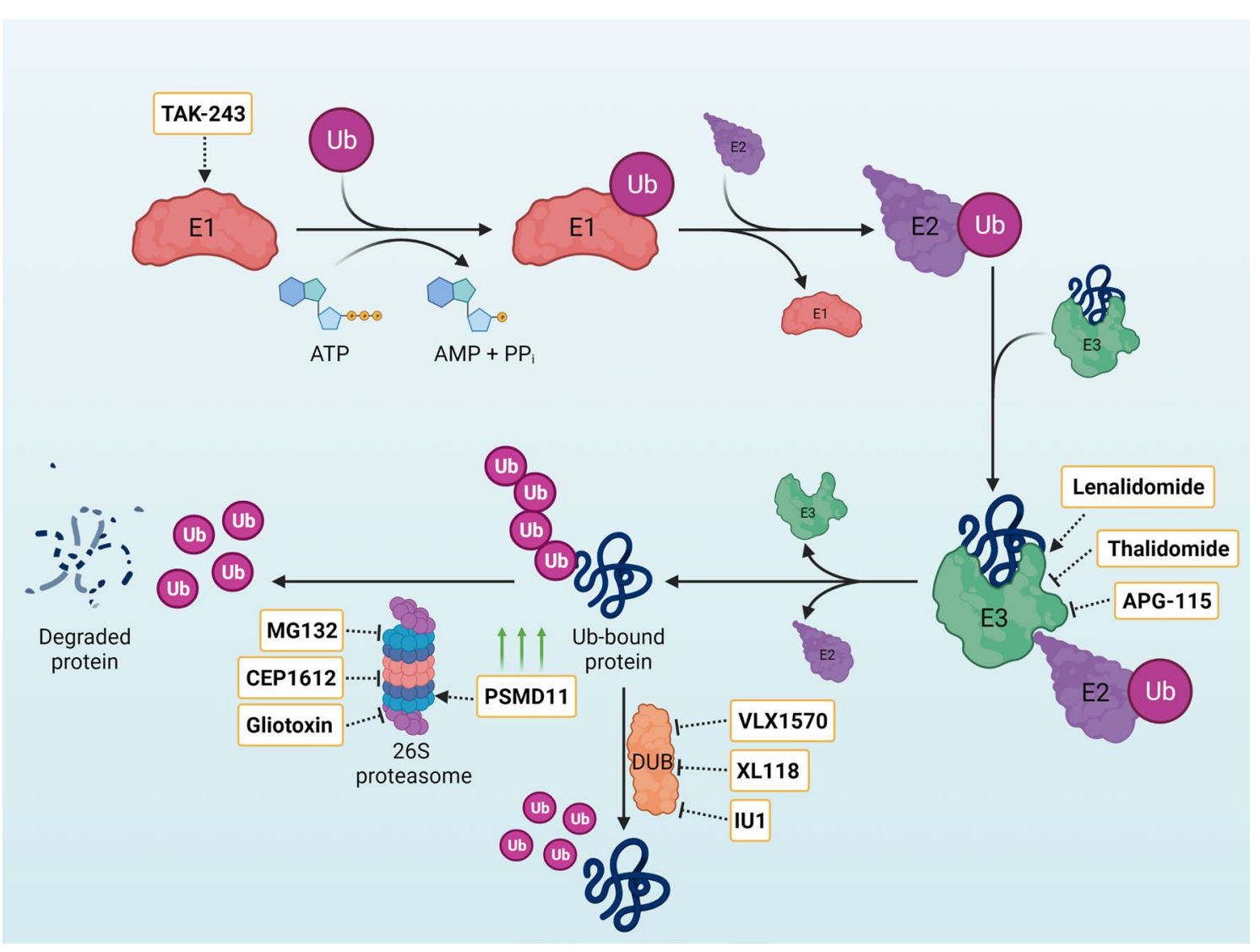

Fig. 2 Modulation of the ubiquitin proteasome system (UPS) for disease intervention. Ubiquitin (Ub) binds to the Ub-activating enzyme E1 by a thioester bond in an ATP-dependent manner and then is transferred to the E2 enzyme. The attachment of $\mathrm{Ub}$ to the target

transformative processes such as cell differentiation or organismal aging (Koyuncu et al. 2021; Saez et al. 2018).

Target proteins can be tagged with $\mathrm{Ub}$ at one lysine residue or multiple lysine residues. Moreover, Ub itself harbors seven internal lysine residues that can form polyUb chains. A Lys48linked polyUb chain is the primary signal for recognition and degradation by the $26 \mathrm{~S}$ proteasome, a multi-catalytic/multi-subunit protease complex that degrades polyubiquitinated proteins to small polypeptides (Hershko and Ciechanover 1998). In addition to lys48, other Ub linkages such as Lys63 or heterotypic chains can also target proteins for degradation (Yau et al. 2017).

\section{Autophagy}

The autophagy-lysosome pathway has a central role in biological processes such as cell differentiation, proliferation, and senescence. Autophagy transfers cytosolic substrates to the lysosome for degradation either in a selective or nonselective manner. The autophagy-lysosome pathway can be distinguished into three types, namely macro-, micro-, and protein is catalysed by E3 ligases. This process can be reversed by deubiquitinating enzymes (DUBs). Ub-tagged proteins are recognized and degraded by the $26 \mathrm{~S}$ proteasome. Inhibitors and activators of the UPS are indicated with dashed lines

chaperone-mediated autophagy (CMA) (Fig. 3a-c) (Klionsky et al. 2011; Levine and Klionsky 2004; Mizushima 2007).

\section{Macroautophagy}

Macroautophagy is the most characterized pathway of autophagy. Macroautophagy not only promotes the recycling of damaged organelles such as mitochondria (mitophagy) and the endoplasmic reticulum (reticulophagy), but also degradation of protein aggregates that cannot be cleared by the UPS (Tasdemir et al. 2007; Youle and Narendra 2011). Macroautophagy is induced by the inactivation of the mammalian target of rapamycin complex 1 (mTORC1), a serine/threonine kinase complex which is sensitive to intra- and extracellular nutrient levels (Ben-Sahra and Manning 2017; Rabanal-Ruiz et al. 2017). Concomitantly, TOR inhibitors such as rapamycin and CCI-779 induce autophagy (Blommaart et al. 1995; Dudkin et al. 2001; Yu et al. 2001). Macroautophagy starts with the formation of a phagophore, 


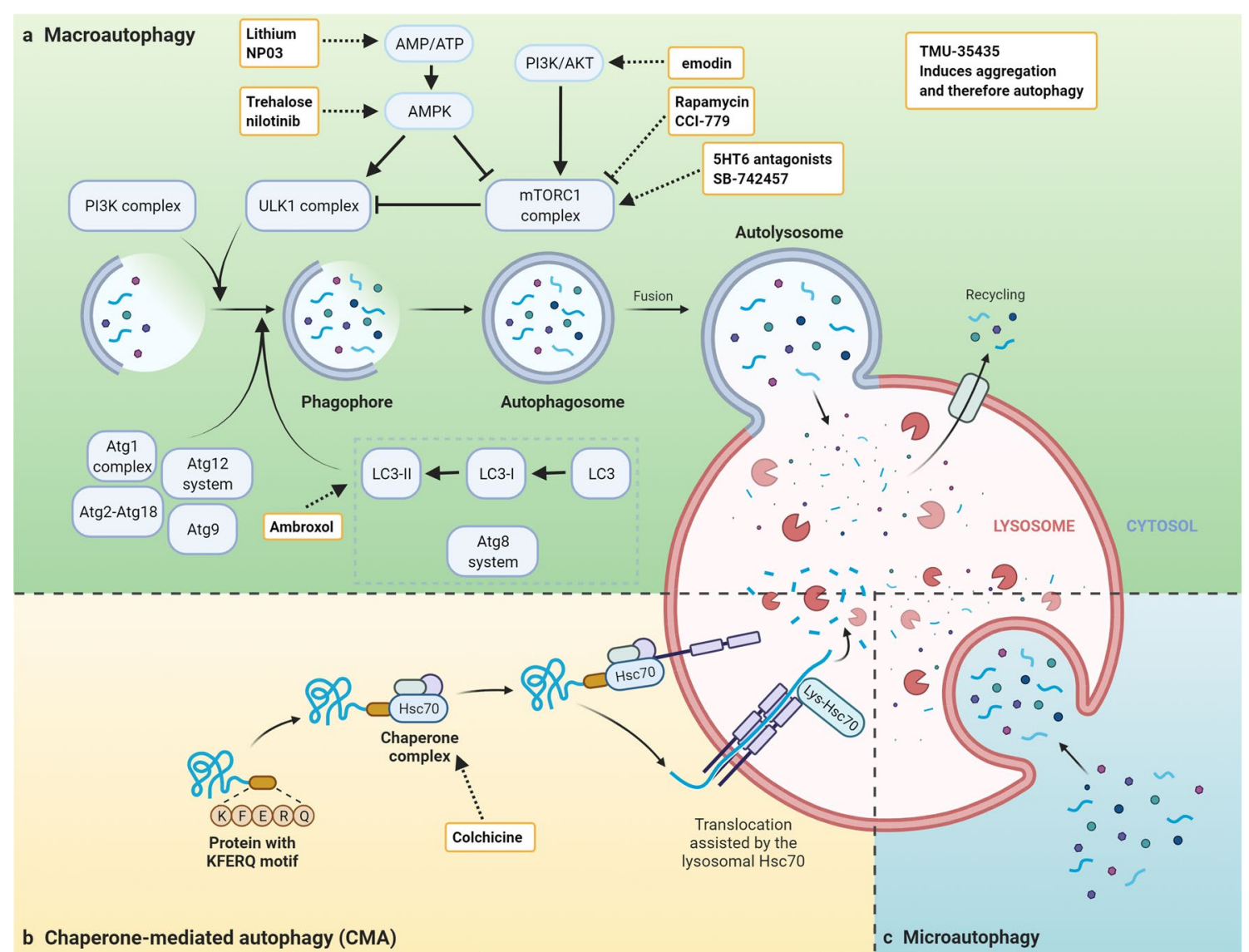

Fig. 3 Modulation of autophagy for disease intervention. a Schematic overview of the macroautophagy pathway. Macroautophagy is induced by inhibition of mTORC1 complex and starts with the formation of a phagophore which matures into the autophagosome. The autophagosome fuses with the lysosome to transfer its cargo. Most inhibitors and activators target the mTORC1 complex either

a vesicle surrounding cytoplasmic material, which turns into the so-called autophagosome. In yeast, autophagosome formation requires 18 autophagy-related (Atg) proteins. The pre-autophagosomal structure is formed by six functional groups of Atg complexes which are highly conserved among eukaryotes, i.e., the Atg1 autophagy initiation complex, Atg9, Atg2-Atg18 complex, the autophagyspecific phosphatidylinositol 3-kinase (Pi3K) complex, the Atg12-Atg-5 conjugation system, and the Atg8-Atg18 Ub-like conjugation system (Suzuki et al. 2017). The closure of the autophagosome is driven by the endosomal sorting complex required for transport (ESCRT) proteins, with CHMP2A being the main regulator (Takahashi et al. 2018). Then, the autophagosome transfers its cargo such as organelles and protein aggregates to the lysosome. During this process, the outer membrane of the autophagosome fuses with the lysosome which then degrades the inner membrane through acidic hydrolases. directly or indirectly. b Schematic overview of chaperone-mediated autophagy (CMA). Proteins harbouring a KFERQ motif are recognized by Hsc70 and translocated to the lysosomal lumen through interaction with LAMP2A. c Schematic overview of microautophagy. Cytosolic substrates are directly transported to the lysosomal lumen. Inhibitors and activators are indicated with dashed lines

\section{Microautophagy}

Microautophagy plays an essential role in cell survival. In contrast to macroautophagy, which requires the formation of an autophagosome, microautophagy transports cytosolic substrates directly to the lysosomal or endosomal lumen (Marzella et al. 1981). In yeast, some types of microautophagy are driven by ESCRT machinery. Particularly, inhibition of mTORC1 upon starvation leads to dephosphorylation of Vps27, a component of ESCRT-0, resulting in the initiation of microautophagy through ESCRT-0 (Hatakeyama and Virgilio 2019). However, the mechanisms underlying microautophagy in multicellular eukaryotes remain elusive.

\section{Chaperone-mediated autophagy (CMA)}

Degradation of proteins through chaperone-mediated autophagy (CMA) is mediated by the cytosolic heat 
shock-cognate chaperone of $70 \mathrm{kDa}$ (Hsc70), also known as heat shock $70 \mathrm{kDa}$ protein 8 (HSPA8). HSPA8 recognizes substrates that contain a specific pentapeptide motif (KFERQ) (Chiang et al. 1989; Dice 1988). This pentapeptide motif becomes accessible when the target protein changes its binding properties or conformation, exposing the KFERQ-motif. The resulting complex interacts with the lysosome-associated membrane protein type-2A (LAMP2A). The binding of LAMP2A to a substrate protein leads to a high-weight multi-protein complex which is required for translocation into the lysosomal lumen (Bandyopadhyay et al. 2008). During the assembly of the LAMP2A-protein complex, the target protein is unfolded to enter the lysosomal lumen through a lysosomal membrane receptor/translocation complex, a process mediated by Hsc 70 and heat shock protein 90 (Hsp90).

\section{Diseases triggered by protein misfolding and aggregation}

The pathological accumulation and aggregation of misfolded proteins is a phenomenon observed in many disorders, including distinct neurodegenerative diseases. Alzheimer's disease (AD), the most common cause of dementia, is characterized by the deposition of two different protein aggregates: (a) senile amyloid- $\beta(A \beta)$ plaques and (b) neurofibrillary tangles of the microtubule-associated protein tau (Nie et al. 2011; Penke et al. 2017; Selkoe, 2011; Snyder et al. 1994). These aggregates can result in synaptic dysfunction and neurodegeneration (Selkoe 2011). Parkinson's disease (PD), the most common movement disorder with age, is characterized by the aggregation of misfolded $\alpha$-synuclein $(\alpha-$ syn), leading to inclusions known as Lewy bodies (Arima et al. 1998; Fares et al. 2021; Takeda et al. 1998). Malfunction of the UPS, CMA and lysosomes are observed in early stages of the disease, suggesting that dysregulation of these proteolytic systems is involved in the pathogenesis of PD (Alvarez-Erviti et al. 2010; Leroy et al. 1998; McNaught et al. 2001). Huntington's Disease (HD) is caused by the expansion of the polyglutamine (polyQ) tract of the huntingtin protein (HTT). Whereas the wild-type HTT protein contains less than 35 polyQ repeats, an expansion of $>35$ polyQ repeats can lead to HD (Shannon 2011; Yushchenko et al. 2018). Expanded polyQ-mutant HTT tends to aggregate in different in vitro and in vivo models. Indeed, cumulative evidence indicates that mutant HTT aggregates directly contribute to neurodegeneration phenotype in HD (Brignull et al. 2006; Djajadikerta et al. 2020; Gruber et al. 2018; Koyuncu et al. 2018; Nagai et al. 2000).

Familial cases of ALS are linked with mutations in one of $>25$ different genes that act in a variety of cellular processes. A handful of genes harbor the majority of familial
ALS mutations, including SOD1, TDP-43, FUS and C9orf72 (Bartoletti et al. 2019). Familial ALS-related mutations in TDP-43 and FUS proteins induce their cytosolic aggregation (Bentmann et al. 2013; Liu-Yesucevitz et al. 2010). Importantly, TDP-43 and FUS-immunoreactive aggregates are also a common feature in sporadic ALS (Giordana et al. 2010; Hx et al. 2010). Likewise, cytosolic inclusions of TDP-43 is also a characteristic of frontotemporal dementia (FTD), the most common form of early-onset dementia (Arai et al. 2006; Neumann et al. 2006). Expanded hexanucleotide (GGGGCC ) repeats in the first intron of $C 9$ orf 72 are the most common cause of familial ALS, accounting for approximately $40 \%$ of familial cases (DeJesus-Hernandez et al. 2011; Renton et al. 2011). The hexanucleotide expansions range between 100 and 4000 repeats in patients, generating homopolymeric dipeptide proteins (e.g., poly-GR, GP, GA, PR) which are prone to aggregation (Ash et al. 2013; Mori et al. 2013). In these lines, C9orf72-associated cases exhibit neuropathological changes characterized by abundant protein inclusions (Cooper-Knock et al. 2012), indicating a link with proteostasis deficits.

Besides neurodegenerative diseases, other disorders are also linked with protein misfolding and aggregation. For instance, the protein p53 forms aggregates in several types of cancer. Missense mutations in TP53, the gene encoding for $\mathrm{p} 53$, have been reported in around $50 \%$ of cancerous tumors (Carson and Lois 1995). Protein aggregation is also observed in viral infections. For instance, the herpesviruses murine cytomegalovirus and herpes simplex virus 1 induce the aggregation and degradation of NF-kappa-B essential modulator (NEMO) and receptor-interacting serine/threonine-protein kinase 1 (RIPK1) to block the innate immune response (Muscolino et al. 2020). Furthermore, the microtubule-associated proteins 1A/1B light chain 3B (LC3) adaptor TBC1D5 was identified as an autophagy receptor for virus-induced protein aggregates (Muscolino et al. 2020).

Given the extensive list of diseases characterized by protein aggregates, it is not surprising that many studies focused on how protein clearance mechanisms impinge on disease and their potential for therapeutics. In Table 1, we have summarized reported components of the UPS and autophagy which could be potential targets for disease intervention. The following sections will provide an overview about recent findings and ongoing trials based on protein clearance mechanisms.

\section{Ubiquitin-proteasome system in disease}

The UPS can modulate the levels of dysregulated proteins and terminate aggregation-prone proteins. As such, UPS dysfunction has been linked to multiple disorders. Since proteasomal degradation of target substrates can be modulated 
Table 1 List of components of the UPS and autophagy related to proteinopathies

\begin{tabular}{|c|c|c|c|c|c|}
\hline Gene name & Model & $\begin{array}{l}\text { Abnormality/Disease } \\
\text { model }\end{array}$ & $\begin{array}{l}\text { Aggregated/Accumu- } \\
\text { lated protein }\end{array}$ & Mutation & Source \\
\hline PIK3C3 & Zebrafish & Postnatal lethality & E-cadherin & PIK3C3 knockout & Zhao et al. (2018) \\
\hline PTEN & Mouse, COS-7 cells & $\mathrm{AD}$ & tau aggregation & $\begin{array}{l}\text { PTEN phosphatase-null } \\
\text { mutation }\end{array}$ & Zhang et al. (2006a,b) \\
\hline TRAF6 & HEK cells & PD & $\begin{array}{l}\text { alpha-synuclein, ubiquit- } \\
\text { inated mutant DJ-1 }\end{array}$ & $\begin{array}{l}\text { DJ-1 }{ }^{\text {L166P }} \\
\text { TRAF6 overexpression }\end{array}$ & Zucchelli et al. (2010) \\
\hline INS & - & $\mathrm{AD}$ & $\begin{array}{l}\text { A } \beta 1-42 \\
\text { (insulin prevents A } \beta 1-42 \\
\text { aggregation in vitro) }\end{array}$ & - & Long et al. (2019) \\
\hline TBK1 & Mouse & FTD, ALS & p62 & $\begin{array}{l}\text { SOD1 } 1^{\mathrm{G} 93 \mathrm{~A}} \\
\mathrm{TBK}^{\mathrm{R} 228 \mathrm{H} / \mathrm{R} 228 \mathrm{H}}\end{array}$ & Gerbino et al. (2020) \\
\hline \multirow[t]{2}{*}{ IRS2 } & Mouse & $\mathrm{AD}$ & $\begin{array}{l}\text { Reduction in aggregated } \\
\mathrm{A} \beta\end{array}$ & $\begin{array}{l}\text { APP }{ }^{\mathrm{K} 670 \mathrm{~N}, \mathrm{M} 671 \mathrm{~L}} \\
\text { IRS2 knockout }\end{array}$ & Killick et al. (2009) \\
\hline & & HD & $\begin{array}{l}\text { Reduction in aggregated } \\
\text { HTT }\end{array}$ & $\begin{array}{l}\text { R6/2 mice } \\
\text { Brain specific, heterozy- } \\
\text { gous IRS2 knockout }\end{array}$ & Sadagurski et al. (2011) \\
\hline TSC1 & HEK cells & TSC & TSC1 & Truncated TSC1 & $\begin{array}{l}\text { Hoogeveen-Westerveld } \\
\text { et al. (2010) }\end{array}$ \\
\hline TSC2 & HEK cells & TSC & $\begin{array}{l}\text { Solubilizing TSC1 } \\
\text { aggregates }\end{array}$ & $\begin{array}{l}\text { Truncated TSC1 } \\
\text { TSC2 co-expression }\end{array}$ & $\begin{array}{l}\text { Hoogeveen-Westerveld } \\
\text { et al. (2010) }\end{array}$ \\
\hline RAB39B & Human & PD & $\begin{array}{l}\text { Lewy Bodies, alpha- } \\
\text { synuclein }\end{array}$ & $\begin{array}{l}\text { Complete deletion of } \\
\text { RAB39B }\end{array}$ & Wilson et al. (2014) \\
\hline \multirow[t]{3}{*}{$\mathrm{BECN}$} & Mouse, HeLa cells & $\begin{array}{l}\text { HIV, Chikunguya and } \\
\text { West Nile virus infec- } \\
\text { tion, HD }\end{array}$ & PolyQ in HeLa & $\begin{array}{l}\text { Heterozygous deletion } \\
\text { of BECN in mouse } \\
\text { Expanded polyQ in } \\
\text { HeLa }\end{array}$ & $\begin{array}{l}\text { Shoji-Kawata et al. } \\
\text { (2013) }\end{array}$ \\
\hline & & $\mathrm{AD}$ & $\mathrm{A} \beta$ & $\begin{array}{l}\text { Human APP } \\
\text { Heterozygous deletion } \\
\text { of BECN }\end{array}$ & Pickford et al. (2008) \\
\hline & & HD & PolyQ & $\begin{array}{l}\text { Expanded polyQ in } \\
\text { HeLa }\end{array}$ & Ashkenazi et al. (2017) \\
\hline ATG7 & Mouse & Neurodegeneration & $\begin{array}{l}\text { Accumulation of ubiqui- } \\
\text { tinated proteins }\end{array}$ & $\begin{array}{l}\text { Conditional knockout of } \\
\text { ATG7 }\end{array}$ & Komatsu et al. (2006) \\
\hline ATG5 & Mouse & Cataracts & $\begin{array}{l}\text { Ubiquitin and p62 posi- } \\
\text { tive aggregates }\end{array}$ & $\begin{array}{l}\text { Lens specific ATG5 } \\
\text { knockout }\end{array}$ & Morishita et al. (2013) \\
\hline RB1CC1 & Mouse & Neurodegeneration & Ubiquitinated protein & $\begin{array}{l}\text { Neural-specific deletion } \\
\text { of RB1CC1 }\end{array}$ & Liang et al. (2010) \\
\hline ATG16L1 & Mouse & $\begin{array}{l}\text { Crohn's disease like } \\
\text { ileitis }\end{array}$ & IRE $1 \alpha$ aggregates & $\begin{array}{l}\text { ATG16L1 deletion in } \\
\text { intestinal epithelial } \\
\text { cells }\end{array}$ & $\begin{array}{l}\text { Tschurtschenthaler et al. } \\
\text { (2017) }\end{array}$ \\
\hline ATG2 & HeLa cells & - & $\begin{array}{l}\text { Aggregation of LC3 and } \\
\text { lipid droplets }\end{array}$ & $\begin{array}{l}\text { siRNA knockdown of } \\
\text { ATG2 }\end{array}$ & Velikkakath et al. (2012) \\
\hline ATG9 & Mouse & axon-specific lesions & $\begin{array}{l}\text { Accumulation of ubiqui- } \\
\text { tinated proteins }\end{array}$ & $\begin{array}{l}\text { Conditional knockout of } \\
\text { ATG9 }\end{array}$ & Yamaguchi et al. (2018) \\
\hline AMBRA1 & Mouse & Embryonic lethality & $\begin{array}{l}\text { Accumulation of ubiqui- } \\
\text { tinated proteins }\end{array}$ & $\begin{array}{l}\text { AMBRA1 gene-trapped } \\
\text { in LacZ }\end{array}$ & Maria Fimia et al. (2007) \\
\hline MTMR14 & Fruit Fly & $\mathrm{AD}$ and $\mathrm{HD}$ & $\begin{array}{l}\text { Knockdown of } \\
\text { MTMR14 decreases } \\
\text { A } \beta 1-42 \text { and polyQ } \\
\text { aggregates }\end{array}$ & $\begin{array}{l}\text { Knockdown of } \\
\text { MTMR14 }\end{array}$ & Xiao et al. (2019) \\
\hline RUBCN & Worm & HD & $\begin{array}{l}\text { Knockdown of RUBCN } \\
\text { decreases polyQ } \\
\text { aggregates }\end{array}$ & Knockdown of RUBCN & Nakamura et al. (2019) \\
\hline ATG101 & Fruit Fly & Neurodegeneration & $\begin{array}{l}\text { Accumulation of ubiqui- } \\
\text { tinated proteins }\end{array}$ & $\begin{array}{l}\text { Loss-of-function muta- } \\
\text { tion of ATG101 }\end{array}$ & Guo et al. (2019) \\
\hline
\end{tabular}


Table 1 (continued)

\begin{tabular}{|c|c|c|c|c|c|}
\hline Gene name & Model & $\begin{array}{l}\text { Abnormality/Disease } \\
\text { model }\end{array}$ & $\begin{array}{l}\text { Aggregated/Accumu- } \\
\text { lated protein }\end{array}$ & Mutation & Source \\
\hline VMP1 & Mouse & PD & $\begin{array}{l}\text { LC3, p62, alpha-synu- } \\
\text { clein aggregation }\end{array}$ & $\begin{array}{l}\text { Deletion of VMP1 in } \\
\text { dopaminergic neurons }\end{array}$ & Wang et al. (2021a; b) \\
\hline UVRAG & Mouse & $\begin{array}{l}\text { Inflammation and } \\
\text { Tumorigenesis }\end{array}$ & $\begin{array}{l}\text { Parkin and p62 positive } \\
\text { aggregates }\end{array}$ & $\begin{array}{l}\text { Inducible UVRAG } \\
\text { truncation mutant }\end{array}$ & Quach et al. (2019) \\
\hline C9ORF72 & Mouse, Fruit Fly, Worm & ALS & $\begin{array}{l}\text { DPR aggregation, RNA } \\
\text { foci }\end{array}$ & $\begin{array}{l}\text { Hexanucleotide repeat } \\
\text { expansion, expression } \\
\text { of DPR constructs }\end{array}$ & $\begin{array}{l}\text { Jiang et al. (2016), } \\
\text { Rudich et al. (2017), } \\
\text { Xu and Xu (2018) }\end{array}$ \\
\hline PSMD12 & Yeast & - & $\begin{array}{l}\text { Aggregation of } \\
\text { PSMD12 }\end{array}$ & $\begin{array}{l}\text { Truncation of PSMD12 } \\
\text { in C-terminal }\end{array}$ & Peters et al. (2015) \\
\hline PSMD11 & Mouse & Embryonic lethality & $\begin{array}{l}\text { Accumulation of ubiqui- } \\
\text { tinated proteins }\end{array}$ & $\begin{array}{l}\text { Inducible PSMD11 } \\
\text { knockout }\end{array}$ & Zhao et al. (2021) \\
\hline PSMC4 & Mouse & Muscle atrophy & $\begin{array}{l}\text { Ubiquitin positive } \\
\text { aggregates }\end{array}$ & $\begin{array}{l}\text { PSMC4 knockout in } \\
\text { muscle }\end{array}$ & Kitajima et al. (2014) \\
\hline PSMC6 & $\mathrm{HeLa}$ & HD & PolyQ aggregation & $\begin{array}{l}\text { Expanded polyQ in } \\
\text { HeLa } \\
\text { PSMC6 overexpression }\end{array}$ & Rousseau et al. (2009) \\
\hline PSMC3 & Human & Cataracts and deafness & $\begin{array}{l}\text { Accumulation of ubiqui- } \\
\text { tinated proteins }\end{array}$ & $\begin{array}{l}\text { missense mutation of } \\
\text { PSMC3 }\end{array}$ & Kröll-Hermi et al. (2020) \\
\hline PSMC5 & $\mathrm{HeLa}$ & HD & PolyQ aggregation & $\begin{array}{l}\text { Expanded polyQ in } \\
\text { HeLa } \\
\text { PSMC5 overexpression }\end{array}$ & Rousseau et al. (2009) \\
\hline PSMF1 & Mouse & $\begin{array}{l}\text { Neurodegeneration, } \\
\text { embryonic lethality }\end{array}$ & $\begin{array}{l}\text { p62 aggregates at neu- } \\
\text { romuscular junction, } \\
\text { accumulation of ubiq- } \\
\text { uitinated proteins }\end{array}$ & $\begin{array}{l}\text { Inducible PSMF1 } \\
\text { knockout }\end{array}$ & Minis et al. (2019) \\
\hline
\end{tabular}

The disease model, accumulated/aggregated proteins and the relevant mutations are indicated in the table. The list of selected genes were obtained from Kyoto Encyclopedia of Genes and Genomes proteasome (map03050) and autophagy- animal (map04140)

at different steps from ubiquitination to proteolytic activity, it provides a mean to prevent proteotoxicity through different pharmacological and genetic approaches (Fig. 2).

\section{Targeting the UPS in neurodegenerative diseases}

Deficiencies in proteasome-mediated degradation contribute to neurodegenerative diseases, including AD, PD, ALS, FTD and HD. For instance, tissue samples from patients exhibit aggregates containing Ub (Lowe et al. 1988; Perry et al. 1987). Parkin is one of the most studied E3 enzymes in the context of neurodegeneration and proteotoxicity. Parkin is a RING-between-RING E3 ligase which, together with the serine/threonine kinase PINK1, has a crucial role in mitochondrial quality control and mitophagy (Beasley et al. 2007; Capili et al. 2004; Fett et al. 2010). Under physiological conditions, the two RING domains of parkin are blocked, leading to its inactivation (Duda et al. 2013; Seirafi et al. 2015). Upon severe mitochondrial damage, the mitochondrial membrane becomes depolarized and recruits parkin. The activation of parkin requires both binding of a phosphoUb and phosphorylation by PINK1 (Gladkova et al. 2018; Koyano et al. 2014; Wauer et al. 2015). Activated parkin ubiquitinates voltage-dependent anion-selective channel 1
(VDAC1), which is only exposed when mitochondria are depolarized. Subsequently, the autophagy adaptors p62, CALCOCO2 and TAX1BP1 are recruited by parkin to initiate the autophagosome formation (Sarraf et al. 2013). There are more than 120 PD-relevant mutations reported in parkin (Cruts et al. 2012; Seirafi et al. 2015). These mutations lead to loss-of-function (LOF), either by compromising parkin integrity or preventing parkin from recognizing its substrates (Wauer and Komander 2013). Cells derived from patients are a useful resource for understanding the role of parkin in PD. Fibroblasts obtained from a family with familial parkin mutations display reduced ATP synthesis, total ATP levels and membrane potential compared to control fibroblasts, indicating mitochondrial dysfunction (Grünewald et al. 2010). Moreover, there is a global increase in oxidized proteins in parkin mutants, a sign of increased reactive oxygen species (ROS). An in vitro study by Jiang et al. successfully produced dopaminergic neurons from iPSCs derived from PD patient fibroblasts (Jiang et al. 2012). These neurons have spontaneous dopamine release, decreased dopamine intake, and elevated ROS levels.

Besides regulating mitochondrial function, parkin impacts on PD-related neurodegeneration by interacting with $\alpha$-syn, which is one of the substrates of parkin (Norris et al. 2015). 
Several studies demonstrated that parkin overexpression can have beneficial effects on $\alpha$-syn toxicity in vitro and in vivo whereas loss of parkin results in the accumulation of $\alpha$-syn (Meng et al. 2020; Petrucelli et al. 2002; Rana et al. 2013; Shimura et al. 2001). Transduction of mutant $\alpha$-syn in the mouse midbrain leads to a sharp decrease in dopaminergic neurons and proteasome activity, which is rescued by parkin induction (Petrucelli et al. 2002). A similar study conducted in fruit flies overexpressing both mutant $\alpha$-syn and parkin in dopaminergic neurons showed that even though parkin improves the survival of these neurons, the levels of $\alpha$-syn levels remained similar when compared to flies that did not overexpress parkin (Yang et al. 2003).

The impact of parkin on the clearance of aggregated proteins extends beyond PD models. $\mathrm{A} \beta$ plaques, which are a common hallmark of $\mathrm{AD}$, can cause mitochondrial swelling, decreased cristae and impaired mitophagy in HEK293 human cell lines. Importantly, parkin overexpression successfully restores mitophagy and reverses mitochondrial fragmentation in A $\beta$-treated HEK293 human cell lines (Wang et al. 2020a,b). Moreover, parkin can diminish toxicity and aggregation of ALS-related SOD1 mutant variants in SH-SY5Y neuroblastoma cells. In particular, parkin promotes Lys63-linked polyubiquitination of misfolded SOD1 in cooperation with UbcH13/Uev1a E2 enzyme, triggering the clearance of aggregation-prone SOD1 through autophagy (Yung et al. 2016). In these lines, in vivo studies on parkin also led to promising results. Overexpression of parkin in $D$. melanogaster extends longevity, without affecting reproductivity, organismal activity and food intake (Rana et al. 2013). Parkin-overexpressing flies have more Lys48-linked polyubiquitinated proteins and less protein aggregates compared with their wild-type counterparts. The ameliorative effects of parkin could be partially explained by its role in degradation of mitofusin, a protein that induces mitochondrial fusion and could eventually promote mitochondrial impairment when upregulated (Poole et al. 2010; Rana et al. 2013; Tanaka et al. 2010). In Drosophila, the levels of mitofusin protein increase during aging. However, overexpression of parkin reduces mitofusin levels in aging flies, with subsequent changes in mitochondrial morphology and increased mitochondrial activity (Rana et al. 2013). Given the potential beneficial role of parkin as a disease modifier, several studies sought to define parking activators. These findings led to the discovery and patent of US-2016/0160205A1 and WO-2018/023029 as small molecule activators of parkin. Currently, there are no in vitro or in vivo data available regarding these molecules (Clark et al. 2020; Miller and Muqit 2019).

Whereas several findings indicate a protective role of parkin, it is important to note that parkin activity could also have negative effects depending on the disease model. For instance, parkin deficiency can slow down PD progression in transgenic mice harboring the disease-causing mutation A30P in $\alpha$-syn (Fournier et al. 2009; Lonskaya et al. 2013). Furthermore, parkin appears to contribute to Lewy body formation through K63-linked polyubiquitination of synphilin-1, a protein interacting with $\alpha$-syn (Lim et al. 2005). Conversely, overexpression of synphilin-1 can suppress the neurotoxicity caused by $\alpha$-syn mutation A53T (Smith et al. 2010). A study on ALS mouse models expressing mutant SOD1 demonstrated that genetic ablation of parkin delays disease progression and prolongs survival (Palomo et al. 2018). In this model, loss of parkin slows down neurodegeneration and ameliorates the loss of mitochondrial dynamics induced by ALS-related SOD1 mutant protein. A potential explanation for these unexpected effects is that the mitochondrial damage triggered by mutant SOD1 could lead to a parkin-mediated chronic activation of mitochondrial quality control, which could inhibit mitochondrial biogenesis and worsen mitochondrial dysfunction (Palomo et al. 2018). Thus, modulation of parkin might have distinct effects depending on the model organism and the proteinopathy.

UBR5 is another potentially relevant E3 ligase in the context of disease. Under normal conditions, iPSCs from HD patients do not accumulate aggregates of polyQ-expanded mutant HTT (Koyuncu et al. 2018). However, the treatment with proteasome inhibitor triggers mutant HTT aggregation in these cells, further supporting a role of the UPS in suppressing the formation of HD-related aggregates. Indeed, iPSCs express elevated amounts of UBR5 compared with their differentiated neuronal counterparts, promoting the ubiquitination of mutant HTT and its degradation by the proteasome. Notably, increasing the levels of UBR5 in HD models is sufficient to promote degradation of mutant HTT and ameliorate its aggregation (Koyuncu et al. 2018). In these lines, Yau and colleagues reported that polyQexpanded mutant HTT is heavily ubiquitinated by heterotypic K11/K48-linked chains in cancer cells, embryonic stem cells and neurons. However, ubiquitination of mutant HTT was abolished by co-depletion of UBR5 and UBR4 (Yau et al. 2017).

Carboxy-terminus of Hsc70-interacting protein (CHIP) has the double function of E3 ligase and co-chaperone, playing an important role in UPS-mediated degradation (Ballinger et al. 1999; Jiang et al. 2001). Dysregulation of CHIP has been linked to different neurodegenerative diseases. Phosphorylation of tau is a signal for CHIP-mediated ubiquitination, and clearance of tau by CHIP increases cell survival in COS-7 cells transfected with constructs expressing both tau and CHIP (Shimura et al. 2004). In addition, CHIP knockout mice that express P301L mutant tau exhibits increased phosphorylated and caspase-3-cleaved tau accumulation (Dickey et al. 2006). Further studies demonstrated that the pathologic isoform of $\mathrm{A} \beta$, namely $\mathrm{A} \beta 42$, decreases CHIP expression and leads to tau accumulation in $3 \times \mathrm{Tg}$ 
mice, which express 3 familial AD-associated mutant variants (amyloid- $\beta$ precursor protein (APP) KM670/671NL, MAPT P301L, and PSEN1 M146V) (Oddo et al. 2008). A recent study on $3 \times \mathrm{Tg}$ mice reported that administrating sulforaphane, an isothiocyanate naturally found in cruciferous vegetables, increases CHIP and Hsp70 levels in mouse brains, correlating with elevated clearance of tau and phosphorylated tau. Concomitantly, sulforaphane alleviates learning and memory deficits in these mouse models, supporting an effect of CHIP upregulation at the physiological level (Lee et al. 2018a, 2018b). CHIP also ameliorates protein aggregation in distinct HD models. Zebrafish embryos injected with expanded-polyQ mutant HTT die after $24 \mathrm{~h}$, but co-injection with CHIP rescues this phenotype. Moreover, deletion of a single allele of CHIP in HD mouse models hastens the aggregation of mutant HTT and the disease progression (Miller et al. 2005). A role of CHIP was also observed in ALS transgenic mouse and cell models that express mutant SOD ${ }^{\mathrm{G} 93 \mathrm{~A}}$. In the cell model, CHIP decreases mutant SOD1 levels by ubiquitinating Hsp/ HSC70, which is an interacting partner of SOD1. In vivo proof of indirect interaction between CHIP and SOD1 was evident by co-localization of CHIP, Ub and SOD1 in the spinal cord of end-stage transgenic AD mice (Urushitani et al. 2004).

The E2 Ub conjugating enzyme UBE2K, also known as huntingtin-interacting protein 2 (HIP2), is also a potential modifier of neurodegenerative diseases. The yeast homologue of UBE2K, Ubc1, modulates aggregation of prion proteins in Saccharomyces cerevisiae. Deletion of Ubc1 increases prion aggregation by reducing degradation of the stress-response protein Lsb2. In turn, Lsb2 cannot promote the aggregation of prion precursor Sup35 (Chernova et al. 2011). By yeast two-hybrid system, it was discovered that human UBE2K interacts with the N-terminus of HTT protein leading to its polyubiquitination, regardless of the length of the polyQ tract (Kalchman et al. 1996). However, knockdown of UBE2K does not lead to increased levels or aggregation of mutant HTT in iPSCs from HD patients (Fatima et al. 2020). Thus, further studies are needed to assess whether UBE2K could be a modifier of HD. Besides its interaction with HTT, a potential link between UBE2K and $A \beta$ aggregation has also been explored. In a mouse model of $\mathrm{AD}, \mathrm{A} \beta$ plaques have increase $\mathrm{UBE} 2 \mathrm{~K}$ expression, which leads to stabilization of caspase-12, eventually causing neuronal death. Conversely, lowering UBE2K levels successfully induces $A \beta$ resistance in cortical neurons and reduces activation of caspase-12 (Song et al. 2008). These results indicate that, like parkin, modulation of UBE2K could have positive or negative roles on protein aggregation depending on the disease and the models analyzed.

DUBs, the enzymes that cleave ubiquitin from proteins, are emerging as key modifiers of aging and disease. In $C$. elegans, there is an increase in global DUB activity during the aging process. Consequently, multiple proteins escape the clean-up by the UPS and accumulate with age, leading to protein aggregation and cellular dysfunction (Koyuncu et al. 2021). Moreover, deregulation of DUBs is involved in many different neurological disorders such as AD, PD, HD, and ALS (Amer-Sarsour et al. 2021; Nazé et al. 2002; Saigoh et al. 1999; Setsuie and Wada, 2007; Zeng et al. 2019). For instance, DUB activity can directly modulate the ubiquitination levels of disease-related proteins such as $\alpha$-syn (Amer-Sarsour et al. 2021; Cartier et al. 2009; Guo et al. 2017; Oishi et al. 2016; Uddin et al. 2018). As such, DUBs are targets for modulating protein clearance in neurodegeneration. USP14 is a proteasome-associated DUB that can inhibit the degradation of ubiquitin-protein conjugates (Lee et al. 2010). The treatment of mouse embryonic fibroblasts (MEFs) with IU1, a small-molecule inhibitor of USP14, improves the clearance of proteotoxic tau, TDP-43, ataxin-3 (ATXN3) and GFAP, which are disease-relevant proteins in AD, ALS, Machado-Joseph disease and glia overactivation, respectively (Lee et al. 2010). Moreover, overexpression of catalytically dead USP14 reduces the levels of prion aggregates in $\mathrm{PrP}^{\mathrm{C}}$-overexpressing Neuro2a mouse neuroblastoma cells (Homma et al. 2015). Importantly, knockdown of USP14 also has beneficial effects in a fruit fly model of PD, where it rescues mitophagy defects caused by PINK1/Parkin mutation and the subsequent disease-related phenotypes (Chakraborty et al. 2018). Whereas reducing USP14 activity can have beneficial effects in distinct disease models, overexpression of USP14 reduces mutant HTT aggregates and counteracts cell degeneration in neural cell lines expressing expanded-polyQ HTT constructs (Hyrskyluoto et al. 2014). In addition, USP14 does not appear to have a robust effect on the cellular levels of tau or TDP-43 in different human cell lines models such as HEK293, U2OS and SH-SY5Y (Ortuno et al. 2016). However, this might be due to methodical differences between the distinct studies (Lee et al. 2010; Ortuno et al. 2016). Nevertheless, these findings demonstrate that USP14 is a potential disease modifier, but its activity could have different effects depending on the disease or the cellular and animal models used in the assays.

USP8 is a relevant DUB in parkin-mediated mitophagy. USP8 removes K6 ubiquitination from parkin, which is required for the recruitment of parkin to mitochondria (Durcan et al. 2014). In addition to its role in mitophagy, USP8 also deubiquitinates K48 and K63-linked Ub chains on $\alpha$-syn (Alexopoulou et al. 2016). Importantly, the knockdown of USP8 significantly reduces $\alpha$-syn levels in SH-SY5Y human cells. This finding was further supported by a fruit fly model which ectopically expresses A53T mutant $\alpha$-syn leading to a rough eye phenotype. The pathological phenotype was successfully rescued upon knockdown of USP8. However, loss of USP8 does not prevent abnormalities 
caused by mutant HTT (Alexopoulou et al. 2016). A further study demonstrated that USP8 can remove K11-linked polyUb chains from p62 (Peng et al. 2020), a regulator of autophagy-mediated clearance of ubiquitinated aggregates. USP8 overexpression leads to deubiquitination of $\mathrm{p} 62$ protein, suppressing its autophagic activity (Peng et al. 2020). However, further studies will be necessary to assess whether the impact of USP8 on autophagy influences disease-related protein aggregation. In addition to USP14 and USP8, other DUBs are also linked with neurodegenerative diseases. For instance, UCH-L1 is downregulated in patients with PD and AD (Setsuie and Wada 2007). Although the impact of $\mathrm{UCH}-\mathrm{L} 1$ on disease is still enigmatic, it has been reported that UCH-L1 not only can function as a DUB, but also as an E3 ligase that extends Lys63-polyUb chains in $\alpha$-syn (Liu et al. 2002). An expanded polyQ mutation in the DUB ataxin-3 causes spinocerebellar ataxia type 3 (SCA3), providing a direct link between DUBs and neurodegeneration (McLoughlin et al. 2020).

Beyond modulation of E3 or DUB enzymes, a global induction of proteasome activity can also prevent the accumulation of disease-related protein aggregates. For instance, increasing the levels of PSMD11/RPN6, a central regulator of proteasome assembly, is sufficient to increase proteasome activity (Vilchez et al. 2012a). Overexpression of $r p n-6$, the worm orthologue of PSMD11, decreases expanded-polyQ aggregation and neurotoxicity in a worm model of HD. Conversely, knockdown of rpn-6 hastens disease-related changes, underlining the importance of PSMD11/RPN6 in removal of disease-relevant protein aggregates (Vilchez et al. 2012b). Another publication demonstrated that cAMP-mediated phosphorylation and subsequent activation of PSMD11 promotes the degradation of disease-related mutant variants of TDP-43, SOD1 and Tau (Lokireddy et al. 2015).

\section{Targeting UPS in cancer}

Cumulative evidence demonstrates that proteasomal activity is elevated in human cancers (Arlt et al. 2009; Chen and Madura 2005; Zhang et al. 2004). Given that high proliferation rates rely on proteasome activity, proteasome upregulation is consistent with the particular requirements of malignant cells. Moreover, the elevated degree of cell divisions and mutation rates characteristic of cancer cells can lead to the accumulation of misfolded proteins, which can activate stress responses and apoptosis. Distinct studies reported protein aggregation in malignant cells (Chen et al. 2017; Chiu et al. 2019; Chou et al. 2019; Huo, 2010; Kanapathipillai 2018; Yang-Hartwich et al. 2015a,b). For instance, p53, one of the most frequently mutated proteins in human cancers, can form aggregates in cancer cells (Chen et al. 2017; Chou et al. 2019; Yang-Hartwich et al. 2015a,b). Since the proteasome eliminates aberrant or damaged proteins that otherwise would be toxic for the cell, upregulation of proteasome activity could provide an advantageous feature for cancer cells to survive amidst proteotoxic conditions (Whitesell and Lindquist 2005). Indeed, inhibition of proteasome activity is a promising therapeutic approach for the treatment of certain types of cancer (Deng et al. 2020; Devoy et al. 2005; Du and Mei 2013; Zhang et al. 2020). Although it is not clear how inhibition of the proteasome particularly affects cancer cells, a number of identified compounds that inhibit proteasome activity can induce apoptosis of malignant cells (Ling et al. 2002; Pei et al. 2003), kill tumor cells (Teicher et al. 1999), enhance radiation sensitivity (Teicher et al. 1999) and overcome drug resistance (Frankel et al. 2000; Hideshima et al. 2001). A potential explanation for this selectivity is that malignant cells show greater sensitivity to the cytotoxic effects of proteasome inhibition compared with non-cancer cells (Delic et al. 1998; Orlowski et al. 1998; Soligo et al. 2001) Bortezomib, a proteasome inhibitor that reversibly inhibits proteasome activity, is approved for the treatment of multiple myeloma (Orlowski and Kuhn 2008; Richardson et al. 2008). Multiple myeloma cells produce elevated amounts of aberrant immunoglobins and, subsequently, rely on proteasomal function for the continual clearance of abnormal proteins (Nencioni et al. 2007; Richardson et al. 2008). Bortezomib is also efficient against hematological malignancies such as Waldenström's macroglobulinemia and mantle cell lymphoma (Belch et al. 2007; Chen et al. 2007; Fisher et al. 2006; Treon et al. 2007). Two second-generation compounds have entered phase II trials; i.e., NPI-0052 and carfilzomib, which also inhibit proteasome activity but have improved pharmacological properties (Chauhan et al. 2005; Kuhn et al. 2007).

Besides global proteasome activity, other components of the ubiquitin-proteasome system can also be a potential therapeutic target for cancer. Of particular interest is UBA1, the first enzyme in the sequential ubiquitination cascade. In vitro assays with TAK-243, an inhibitor of UBA1, led to global reductions of ubiquitinated protein levels, impaired signaling, arrested cell cycle and cell death due to proteotoxic stress, which was also supported by xenograft models of cancer (Hyer et al. 2018). In 2014, the pharmaceutical company Takeda Oncology started a phase I trial with TAK-243 in patients with advanced solid tumors (NCT02045095). However, the trial was terminated due to realignment of the sponsor's pipeline program, without a publication of the existing results. Nevertheless, a new phase I trial is currently ongoing to assess TAK-243 efficiency in patients with different kinds of recurrent leukemia (NCT03816319). Distinct tripartite motif (TRIM) E3 ligases that modulate protein aggregation and proteasome activity in cancer cells are also potential therapeutic targets (Hatakeyama 2011; Meroni and Diez-Roux 2005). Among them, the E3 ligase 
TRIM25 is strongly upregulated under endoplasmic reticulum (ER) stress in colon and liver carcinoma cells (Liu et al. 2020a,b,c). Increased TRIM25 levels promote the removal of a transcription factor Keap1, which itself is an inhibitor of Nrf2, a regulator of antioxidant responses. In turn, Nrf2 improves survival of tumor cells under ER stress. Notably, mice grafted with stable TRIM25-knockdown cells have slower tumor progression and increased lifespan (Liu et al. 2020a,b,c). Another study revealed that TRIM11 overexpression in the colon cancer cell line HCT116 facilitates removal of both misfolded and normally folded proteins by suppressing the DUB activity of UPS14, increasing the overall proteasome activity. TRIM1 1 overexpression also increases cell survival after proteotoxic conditions such as heat-shock stress. When immunodeficient mice are grafted with HCT116 overexpressing TRIM11, the tumor volume expansion is significantly higher. Conversely, grafts overexpressing USP14 exhibit a slower expansion than those with endogenous levels of USP14 (Chen et al. 2018a,b). Although USP14 activity ameliorates pathological changes in this cancer model through inactivation of the proteasome, USP14 can also have pro-malignant effects in other cancer types. For instance, USP14 is upregulated in patients with lung or breast cancer. The combination of enzalutamide, a nonsteroidal antiandrogen, with either knockdown or pharmacological inhibition of USP14 promotes arrest of cell cycle progression and induces apoptosis (Xia et al. 2019). When lung cancer cells are treated either with USP14 inhibitor or USP14 siRNA, they have decreased proliferation and invasion (Han et al. 2019). Moreover, mice models with either homozygous or heterozygous deletion of p53 display slower tumor progression and increased lifespan when treated with the USP14 inhibitor IU1. In these mouse models, IU1 induces senescence, cell cycle arrest and apoptosis in malignant cells (Ma et al. 2020).

\section{Autophagy in disease}

Deficits in autophagy are associated with multiple diseases (Frake et al. 2015; Jin and Zhang, 2020; Nixon 2013; Park et al. 2020; Towers et al. 2020; White 2015; Yin et al. 2018; Yun and Lee 2018; Zhou et al. 2019). Additionally, autophagy can be induced in many different cell types through inhibition of mTOR with different available inhibitors, most famously rapamycin (Sehgal et al. 1975). Due to its involvement in many different diseases along with the possibility of pharmacological manipulation, autophagy has been a favorable target for therapeutic approaches (Fig. 3).
Targeting autophagy in neurodegenerative diseases

A plethora of evidence demonstrates that autophagy is involved in the clearance of aggregated proteins characteristic of neurodegenerative disorders, establishing autophagy as a central point of interest for therapeutics (Bjørkøy et al. 2005; Jung et al. 2020; Luo et al. 2020; Ravikumar et al. 2002, 2004; Sarraf et al. 2020; Webb et al. 2003). Multiple studies assessed whether induction of autophagy through rapamycin can alleviate hallmarks of $\mathrm{AD}$ such as protein aggregation and neuronal loss. In a mouse model for AD, which overexpresses a V717F mutant variant of human APP, rapamycin-supplemented diet improves learning and memory deficits in Morris water maze (MWM) tests. Moreover, rapamycin-treated animals have less $A \beta 1-42$ aggregates, a clear indication of functional restoration in parallel with protein aggregation clearance (Spilman et al. 2010). An intriguing follow-up study using $3 \times \mathrm{Tg}$-AD mice revealed that rapamycin can prevent $\mathrm{AD}$ only when administrated early in life, and has negligible effects on $A \beta$ and tau aggregates when administered in advanced stages of the disease (Majumder et al. 2011). Since AD begins to develop in patients decades before the first symptoms appear, it is important to determine an administration regimen for therapeutic compounds in AD (Beason-Held et al. 2013; Lloret et al. 2019).

Recent studies on the interplay of diabetes mellitus with $\mathrm{AD}$ also led to promising results. Rat models of type 2 diabetes mellitus (T2DM) induced by streptozotocin (STZ) have increased dystrophic neurites together with aggregation of APP, phosphorylated tau and $\mathrm{A} \beta$, mimicking AD symptoms (Li et al. 2007). However, rapamycin alleviates AD-related protein aggregation and learning deficits in these rat models through inhibition of AMPK-mTOR signaling (Sun et al. 2019). An independent study further supported these results in STZ-induced T2DM rats (Ding et al. 2021). STZ leads to hyperactivation of the mTOR/p70S6k pathway, which can be attenuated by rapamycin treatment. Rapamycin further protects against hippocampal oxidative stress damage, dysregulated mitochondrial activity, and memory impairment along with reduction of A $\beta 1-42$ and hyperphosphorylated tau levels in the hippocampus. Despite the evidence supporting a positive correlation of autophagy induction with amelioration of $\mathrm{AD}$, currently no clinical data trial data are available.

Similar to AD, cellular and animals models of HD treated with rapamycin and other mTOR inhibitors exhibit reduced protein aggregation (King et al. 2008; Ravikumar et al. 2004; Rubinsztein and Nixon 2010). A study using COS-7 cells expressing polyQ-expanded exon 1 of HTT indicates that $\mathrm{mTOR}$ can be sequestered into polyQ aggregates. Interestingly, sequestration of mTOR increases autophagy, as supported by increased levels of the autophagosome marker 
LC3-II. Moreover, the rapamycin analog CCI-779 promotes clearance of protein aggregates and ameliorates motor deficits in mice expressing mutant HTT (Ravikumar et al. 2004). A recent study demonstrated that a small molecule inhibitor of serine/threonine kinase GSK-3 can promote clearance of expanded-polyQ HTT aggregates (Rippin et al. 2021). GSK-3 was initially identified as a central kinase involved in glucose metabolism, which phosphorylates glycogen synthase, insulin receptor 1, phosphoenolpyruvate carboxykinase and glucose 6-phosphatase (Embi et al. 1980; Liberman and Eldar-Finkelman 2005; Lochhead et al. 2001). Further studies reported that inhibition of GSK-3 leads to increased autophagy in distinct cell types, mainly cancer cells (Gavilán et al. 2013; Marchand et al. 2015; Ren et al. 2018; Ryu et al. 2021). Notably, the GSK-3 inhibitor L807mts enhances clearance of aggregates through elevated autophagy in $\mathrm{SH}$ SY5Y cells expressing mutant HTT. Moreover, L807mts improves motor function and coordination in R6/2 mice, a widely used mouse model for HD (Rippin et al. 2021).

Besides AD and HD, induction of autophagy via mTOR inhibition could also be a modifier of other neurodegenerative diseases. In PD models, mutant $\alpha$-syn can impair autophagy itself (Xilouri et al. 2009). Rapamycin reduces death of PC12 neuronal cells treated with 6-hydroxydopamine (6-OHDA), a compound that selectively destroys dopaminergic and noradrenergic neurons mimicking the neurodegeneration characteristic of PD. Moreover, rapamycin also prevents neuronal death in mice treated with 1-methyl-4-phenyl-1,2,3,6-tetrahydropyridine (MPTP), a compound that causes selective destruction of dopaminergic neurons in substantia nigra used for PD modeling (Malagelada et al. 2010). Beyond pharmacological-induced models, rapamycin can also have beneficial effects on PD genetic models. For instance, rapamycin improves motor function in mice that express the PD-associated A53T mutant variant of $\alpha$-syn, without altering the total levels of $\alpha$-syn (Bai et al. 2015). A more recent study indicated that rapamycin, but not PF-4708671, a molecule that inhibits a downstream target of mTORC1 (i.e., ribosomal protein S6 kinase), can attenuate depression/anxiety-like behavior in 6-OHDAtreated mice (Masini et al. 2018). Another agent enhancing autophagy is resveratrol, which activates the AMPK/SIRT1 pathway. In a PC12 cell line overexpressing mutant $\alpha$-syn, resveratrol treatment leads to increased clearance of $\alpha$-syn (Wu et al. 2011). The therapeutic potential of AMPK activation is further supported by experiments in D. melanogaster models for PD, whereby using the agent 5 -amino- $1-\beta$-Dribofuranosyl-imidazole-4-carboxamide (AICAR) to activate AMPK reduces cell death ( $\mathrm{Ng}$ et al. 2012). Likewise, the AMPK activating agent metformin results in decreased cell death in both MPTP-treated mice and a D. melanogaster model for PD (Ng et al. 2012; Patil et al. 2014). In mice overexpressing A30P mutant $\alpha$-syn, the PREP-inhibitor
KYP-2047 enhances the clearance of $\alpha$-syn via induction of beclin-1 and subsequent enhancement of autophagy (Savolainen et al. 2014). In N2A cells overexpressing A30P and A53T $\alpha$-syn, beclin-1 activation through isorhynchophylline treatment has similar effects ( $\mathrm{Lu}$ et al. 2012). Moreover, activation of the transcription factor EB (TFEB) induces autophagy and clearance of $\alpha$-syn aggregates in human neuroglioma cells overexpressing $\alpha$-syn (Kilpatrick et al. 2015). An extensive discussion on autophagy-enhancing agents that ameliorate PD in various models can be found in the review published by Moors and colleagues in 2017 (Moors et al. 2017).

In addition to compounds that inhibit mTOR and induce autophagy, several studies investigated agents that can affect the lysosome (Bourdenx et al. 2016; McNeill et al. 2014; Richter et al. 2014). Mutations in GBAl, a gene encoding for the lysosomal enzyme $\beta$-Glucocerebrosidase (GCase), is a risk factor for PD (Sidransky et al. 2009; Sidransky and Lopez 2012). These mutations can lead to functional loss of GCase and thereby to lysosomal dysfunction and accumulation of $\alpha$-syn (Bae et al. 2015; Yap et al. 2011). Ambroxol, a substrate targeting GCase, increases GCase activity and restores the lysosomal function in GBA1 mutant fibroblasts (McNeill et al. 2014). Another substrate that targets GCase is isofagomine. Notably, the treatment with isofagomine reduces the levels of $\alpha$-syn and neuroinflammation in mice overexpressing $\alpha$-syn, improving their motor performance (Richter et al. 2014).

Importantly, mutations in distinct autophagy-related genes, such as p62/SQSTM1, OPTN, C9orf72, ALS2, UBQLN2 can cause ALS (Renton et al. 2014). Indeed, defective autophagy has been reported in ALS patients and models, supporting the potential of autophagy enhancement as a therapeutic approach in ALS (Chen et al. 2018a, b; Goode et al. 2016; Lee et al. 2018a,b; Majcher et al. 2015). Nonetheless, ALS models treated with mTOR inhibitors have showed conflicting results. For instance, rapamycin does not alleviate the accumulation of protein aggregates in mutant SOD1-expresssing mice, and hastens motor neuron degeneration and organismal death in these animals (Zhang et al. 2011). A following study using a different mutant SOD1 mouse model confirmed that rapamycin do not have beneficial effects on ALS pathology, while dietary restriction increases lifespan and delays the onset of the disease (Bhattacharya et al. 2012). Nevertheless, a report using a microphysiological 3D model of ALS-related mutant TDP43 consisting of motor neurons and muscle fibers differentiated from patient-derived iPSCs revealed that the treatment with rapamycin restores the functionality of motor neurons. Moreover, rapamycin decreases TDP-43 aggregation and apoptosis in these cells (Osaki et al. 2018). A different study using mutant OPTN-expressing mice as a model for ALS also supported the idea of rapamycin as a potential candidate 
for ALS treatment. Indeed, administering mutant OPTNexpressing mice with rapamycin leads to a rescue in their behavioral deficits as well as decreased TDP-43 aggregation (Zhang et al. 2021a).

Since rapamycin is a potent immunosuppressor which is also contraindicated for people with renal insufficiency, it is important to develop alternatives for autophagy induction (Baroja-Mazo et al. 2016; Ruggenenti et al. 2016). Recent advances on autophagy regulation allowed researchers to enhance autophagy through mTOR-independent pathways such as lithium administration, which is also used to treat bipolar and major depressive disorders (Motoi et al. 2014; Sarkar et al. 2005). Lithium activates autophagy pathway by inhibiting inositol phosphatase-phosphatase (IMPase). Under physiological conditions, IMPase facilitates the hydrolysis of inositol monophosphate into free inositol (Maeda and Eisenberg 1980). Inhibition of IMPase by lithium leads to depletion of free inositol, and ultimately decreases inositol triphosphate (IP3) levels (Sarkar et al. 2005). Subsequently, IP3 receptor is less active, impairing intracellular $\mathrm{Ca}^{2+}$-sensing mechanisms, a process that compromises mitochondrial function and ATP production. Then, increased AMP/ATP ratio activates autophagic pathways through AMPK kinase (Cárdenas et al. 2010; Decuypere et al. 2011). The treatment of AD mice models with lithium has led to mixed results. An earlier report demonstrated that the chronic treatment with lithium improves spatial learning deficiencies in rats injected with pre-formed $A \beta$ (De Ferrari et al. 2003). Lithium also induces a significant reduction of phosphorylated tau levels in 3xTg-AD mice, but it does not has beneficial effects on $\mathrm{A} \beta$ aggregation or memory deficiencies (Caccamo et al. 2007). More recent studies supported that microdosing of lithium is beneficial for AD models. Mutant APP-expressing rats treated with NP03, a microdose formulation of lithium, exhibit reduced $A \beta$ aggregation, improvements in working memory, decreased inflammation and lower oxidative stress (Wilson et al. 2020). Another study reported that APP transgenic mice treated with low doses of lithium exhibit a recovery in spatial learning. The same study found decreased levels of phosphorylated tau and $A \beta$ aggregates in the brain of mice treated with lowdose lithium (Liu et al. 2020a,b,c). In addition, low-dose lithium treatment can also have anti-pathological effects in HD models. NP03-treated YAC128 mice, which express human expanded-polyQ mutant HTT, have improved motor function and decreased neuropathological deficits in the brain. Moreover, NP03 diminishes insoluble mutant HTT aggregates and phosphorylated tau (Pouladi et al. 2012).

In different models of PD, lithium treatment produces varying outcomes. When dopaminergic N27 cells are treated with $\mathrm{H}_{2} \mathrm{O}_{2}$, they have decreased survival compared to cells treated with both $\mathrm{H}_{2} \mathrm{O}_{2}$ and lithium, as a consequence of oxidative stress. Moreover, lithium treatment prevents oxidized/ nitrated $\alpha$-syn accumulation in brains of PD mice that overexpress mutant $\alpha$-syn (Kim et al. 2011). In contrast, Yong and colleagues reported that 6-OHDA-induced models of PD mice do not exhibit increased survival of dopaminergic neurons upon lithium treatment. Although phosphorylated tau levels were decrease in this mouse model upon lithium, the treatment did not have any effect on PD neuropathology (Yong et al. 2011). However, another study showed enhanced dopaminergic differentiation when neural stem cells (NSCs) treated with lithium were transplanted into 6-OHDA-induced PD rat models when compared with NSCs treated with vehicle (Qi et al. 2017). In addition, NSCs treated with lithium rescue motor function in this PD model (Qi et al. 2017). Together, these data indicate that even though lithium treatment alone may not be sufficient therapy for PD, it can have complementary beneficial effects in combination with an effective treatment.

Lithium can also lead to different results depending on the ALS model. In mutant SOD $1^{\mathrm{G} 93 \mathrm{~A}}$ - transgenic mice, lithium treatment prevents neurodegeneration, increases lifespan and delays the disease onset, correlating with a reduction in aggregates containing Ub and SOD1. The same study also reported a clinical trial, where ALS patients were treated with either only riluzole or riluzole combined with lithium and showed that combined therapy could have beneficial effects (Fornai et al. 2008). However, a following study refuted these claims using SOD $1^{\mathrm{G} 93 \mathrm{~A}}$-mutant mice in two different genetic backgrounds. Pizzasegola et al. (2009) found no significant differences between vehicle- or lithiumtreated mice in terms of disease duration or neuroprotection. Instead, they observed an early onset of the disease and decreased survival.

\section{Targeting autophagy in cancer}

The link between autophagy and cancer has been known since decades. However, the specific role of autophagy in cancer development remains elusive. As discussed in previous sections, mutations in the protein p53 lead to its misfolding and aggregation in cancerous cells (Carson and Lois 1995). Under physiological conditions, p53 serves as a tumor suppressor and regulates the autophagy-lysosomal pathway. Whereas nuclear p53 induces autophagy by activating the sestrin-AMPK-mTOR pathway, cytosolic p53 acts as an autophagy inactivator through mTOR (Budanov and Karin 2008; Chollat-Namy et al. 2019; Tasdemir et al. 2008). A study of Haque et al. (2018) linked cytosolic p53 aggregates with lung cancer. Using a human lung cancer cell line, they observed cytosolic p53 aggregation despite that $T P 53$, the gene encoding for $\mathrm{p} 53$, did not harbor any mutation. The autophagic protein ATG5 co-aggregates with p53 and, subsequently, loses its physiological function. Treating lung cancer cells with the compound emodin diminishes 
the interaction between aggregating p53 and ATG5, leading to an increase in the autophagy flux that reduces protein aggregates. Intriguingly, induction of aggregate formation could also support anti-cancer therapies. A novel histone deacetylase inhibitor TMU-35435 can induce aggregation of misfolded proteins and thereby autophagy in triple-negative breast cancer (TNBC) (Chiu et al. 2019). Remarkably, treating mouse models of orthotopic breast cancer with both, TMU-35435 and irradiation, suppresses tumorigenesis through autophagy induction. Thus, either inhibition or activation of autophagy could have beneficial effects for cancer therapy depending on the type of cancer and the aggregated proteins.

\section{Targeting autophagy in inflammatory and infectious diseases}

Many viruses have been reported to impinge on the autophagy-lysosome pathway. However, not all these viruses cause an infection that correlates with protein aggregation. A virus which could promote protein aggregation is the severe acute respiratory syndrome coronavirus 2 (SARS-CoV-2), which causes COVID-19. Patients with COVID-19 are predicted to have a higher risk to develop neurodegenerative diseases (Chana-Cuevas et al. 2020; Dolatshahi et al. 2021; Tavassoly et al. 2020). The analysis of potential effects of SARS-CoV-2 proteins indicates that the infection interferes with autophagosome-lysosome fusion (Miao et al. 2021; Zhang et al. 2021b). Particularly, the open reading frame 3a (ORF3a) of SARS-CoV-2 blocks the fusion between autophagosomes and lysosomes and thus the autophagic flux. ORF3a was found to interact with VPS39, a process that prevents the assembly of fusion machinery, leading to the accumulation of autophagosomes (Miao et al. 2021; Zhang et al. 2021b). Notably, disruption of ORF3a-VPS39 interaction by a point mutation diminishes the blocking effect of ORF3a. These new insights could enable researchers to develop therapies that target the fusion between the autophagosome and lysosome to diminish infection and the resulting protein aggregation. In 2019, Masaki and colleagues found protein aggregates triggered by Theiler's murine encephalomyelitis virus (TMEV) infection. The protein TDP-43, which aggregates in ALS and FTD, exhibits abnormal cellular localization and phosphorylation upon infection with TMEV (Masaki et al. 2019).

Patients of the genetic disorder cystic fibrosis (CF) typically present chronic inflammation in their lungs. Interestingly, CF patients display the accumulation of protein aggregates in their airways hinting to a possible role of protein clearance mechanisms such as autophagy (Brockman et al. 2017; Luciani et al. 2010). CF is caused by mutations in the cystic fibrosis transmembrane conductance regulator (CFTR) (Ratjen and Döring 2003). In 2010, Luciani and colleagues linked defective CFTR with dysfunctional autophagy and reduced clearance of aggresomes (Luciani et al. 2010). Since then, many studies sought to understand the link between CFTR and autophagy to develop therapeutic approaches. Targeting macroautophagy by silencing BAG3, a co-chaperone that mediates selective macroautophagy, corrects trafficking defects caused by the diseaserelated F508del-CFTR mutant variant. A similar effect was reported for other disease-causing mutations in CFTR, i.e., G85E, R560T and N1303K. Although targeting the UPS by silencing BAG1 also has beneficial effects, targeting autophagy provides more promising results (Hutt et al. 2018).

\section{Clinical trials on proteolytic systems to prevent protein aggregation}

One of the challenges for the clinical treatment of proteinopathies is the selection of targets and drugs. The UPS, autophagy, and the aggregating proteins themselves might be a potential target for disease intervention (please see Table 2 for a summary of clinical trials and preclinical studies discussed in this section). Furthermore, the rationale on how a drug would affect the course of the disease is also different for cancer and neurodegeneration. Regarding cancer, the primary goal is to prevent protein clearance mechanisms from functioning properly with the aim to induce a proteostasis collapse in malignant cells, leading to reduced proliferation and invasion (Almond and Cohen, 2002; Crawford et al. 2011; Liu et al. 2020a,b,c; Manasanch and Orlowski 2017; Mulcahy Levy et al. 2017; Mulcahy Levy and Thorburn 2020). In neurodegenerative diseases that involve protein inclusions, many approaches seek to upregulate or rescue protein clearance systems to prevent pathological protein aggregation (Corti et al. 2020; Menzies et al. 2017; Nah et al. 2015; Schmidt et al. 2021; Watanabe et al. 2020). As ongoing therapies and clinical trials for cancer have been discussed in previous sections, here we will focus on interventions that could alleviate neurodegenerative diseases. The disparities between the pathophysiology of distinct proteinopathies led to exploring many different types of interventions for preventing protein aggregation (Arosio et al. 2014; Hyun and Shin 2021; Lashuel 2021; Salahuddin et al. 2021). Such interventions can be classified as antibodies, protein stabilizers, nanoparticles, sequestering monomers and small molecule inhibitors of aggregation.

Immunization with antibodies against toxic protein aggregates provided promising results in preclinical studies. An early study demonstrated that immunization against $A \beta_{42}$ reduces neuronal $A \beta$-plaque deposition and ameliorates behavioral deficits in AD mouse models that overexpress human APP (Schenk et al. 1999). Two further independent 
Table 2 List pre-clinical and clinical trials to prevent protein aggregation and ameliorate neurodegenerative diseases

\begin{tabular}{|c|c|c|c|c|c|}
\hline Disease & Agent & Effect & Clinical Phase & Trials & Publication \\
\hline $\mathrm{AD}$ & Immunization against $A \beta 42$ & $\begin{array}{l}\text { Reduced neuronal } \\
\text { A } \beta \text {-plaque deposition; } \\
\text { ameliorates behavioral } \\
\text { deficits }\end{array}$ & Pre-Clinical & $-1-$ & Schenk et al. (1999) \\
\hline $\mathrm{AD}$ & Curcumin & $\begin{array}{l}\text { Prevent aggregation of tau, } \\
\text { A } \beta \text { and } \alpha \text {-syn }\end{array}$ & Pre-Clinical & $-1-$ & $\begin{array}{l}\text { Pandey et al. (2008), Rane } \\
\text { et al. (2017), Sharma and } \\
\text { Nehru (2018), Yang et al. } \\
\text { (2005) }\end{array}$ \\
\hline $\mathrm{AD}$ & Aducanumab & $\begin{array}{l}\text { Monoclonal antibody } \\
\text { targeting } \mathrm{A} \beta\end{array}$ & Approved & NCT02484547 & Dunn et al. (2021) \\
\hline $\mathrm{AD}$ & Tafamidis meglumine & Prevents amyloidogenesis & Approved & $-1-$ & Unpublished \\
\hline $\mathrm{AD}$ & sulforaphane & $-1-$ & Recruiting & NCT04213391 & Unpublished \\
\hline $\mathrm{AD}$ & Rapamune & $-1-$ & Early phase 1 & NCT04200911 & Unpublished \\
\hline $\mathrm{AD}$ & Trehalose & $-1-$ & Phase 1 & NCT04663854 & Unpublished \\
\hline $\mathrm{AD}$ & Curcumin & $\begin{array}{l}\text { No clinical or biochemical } \\
\text { improvements }\end{array}$ & Phase 2 & NCT00099710 & Ringman et al. (2012) \\
\hline $\mathrm{AD}$ & Epigallocatechin-Gallate & $\begin{array}{l}\text { Prevents the aggregation of } \\
\text { beta-amyloid }\end{array}$ & Phase 2 & NCT00951834 & Unpublished \\
\hline $\mathrm{AD}$ & Lithium Carbonate & $\begin{array}{l}\text { Mitigated cognitive decline; } \\
\text { modified AD-related CSF } \\
\text { biomarkers }\end{array}$ & Phase 2 & NCT01055392 & Forlenza et al. (2019) \\
\hline $\mathrm{AD}$ & Methylene blue; TRx0014 & $\begin{array}{l}\text { Improvement of cognitive } \\
\text { function }\end{array}$ & Phase 2 & NCT00515333 & Wischik et al. (2015) \\
\hline $\mathrm{AD}$ & Rapamycin & $-1-$ & Phase 2 & NCT04629495 & Unpublished \\
\hline $\mathrm{AD}$ & $\begin{array}{l}\text { 5-HT6 antagonist; } \\
\text { SB-742457 }\end{array}$ & $\begin{array}{l}\text { Improvement of cognitive } \\
\text { function }\end{array}$ & Phase 2 & $\begin{array}{l}\text { NCT00348192; } \\
\text { NCT00710684; } \\
\text { NCT00708552 }\end{array}$ & $\begin{array}{l}\text { Maher-Edwards et al. (2015, } \\
\text { 2010) }\end{array}$ \\
\hline $\mathrm{AD}$ & Hydralazine hydrochloride & $-1-$ & Phase 3 & NCT04842552 & Unpublished \\
\hline $\mathrm{AD}$ & $\begin{array}{l}\text { Leucomethylene blue; } \\
\text { TRx0237 }\end{array}$ & $-1-$ & Phase 3 & NCT03446001 & \\
\hline $\mathrm{AD}$ & $\begin{array}{l}\text { Leucomethylene blue; } \\
\text { TRx } 0237\end{array}$ & Reduced brain atrophy & Phase 3 & NCT01689246 & Wilcock et al. (2018) \\
\hline ALS & Colchicine & $-1-$ & Phase 2 & NCT03693781 & $\begin{array}{l}\text { Cadwell (2016), Mandrioli } \\
\text { et al. (2019), Zhao et al. } \\
\text { (2015) }\end{array}$ \\
\hline ALS & Rapamycin & $-1-$ & Phase 2 & NCT03359538 & Unpublished \\
\hline ALS & Tamoxifen & $\begin{array}{l}\text { Moderate effects on ALS } \\
\text { score of functional scale }\end{array}$ & Phase 2 & NCT02166944 & Chen et al. (2020) \\
\hline PD & Nilotinib & $\begin{array}{l}\text { Improved cognitive and } \\
\text { motor functions }\end{array}$ & Early Phase 1 & NCT02281474 & Pagan et al. (2016) \\
\hline PD & Ambroxol & $\begin{array}{l}\text { Improvement of cognitive } \\
\text { function }\end{array}$ & Phase 2 & $\begin{array}{l}\text { NCT02914366; } \\
\text { NCT04388969 }\end{array}$ & Mullin et al. (2020) \\
\hline PD & Nilotinib & No symptomatic benefits & Phase 2 & NCT03205488 & Simuni et al. (2021) \\
\hline
\end{tabular}

The disease, molecular agent and its effects as well as the clinical trial status are indicated. Trial numbers derived from clinicaltrials.gov

studies supported these findings, boosting the confidence in immunization studies (Janus et al. 2000; Morgan et al. 2000). A potential explanation for these beneficial effects is that antibodies promote the clearance of amyloid plaques through phagocytosis mediated by $\mathrm{Fc}$ receptor, which is a surface protein found in many different types of immune cells (Bard et al. 2003; Salahuddin et al. 2021). Unfortunately, these studies came to a halt when early clinical trials resulted in serious side effects, including a death due to meningoencephalitis (NCT00021723) (Neugroschl and Sano 2010). In June 2021, the United States Food and Drug Administration (FDA) approved aducanumab, a monoclonal antibody targeting $\mathrm{A} \beta$ in brains of patients in early stages of $\mathrm{AD}$, providing a new hope for immunization against proteinopathies (Dunn et al. 2021). A similar immunization strategy was also investigated for aggregated SOD1 in ALS. Active immunization 
against human SOD1 ${ }^{\mathrm{G} 93 \mathrm{~A}}$ induced the clearance of SOD1 in the spinal cord of mice expressing SOD $1^{\mathrm{G} 37 \mathrm{R}}$ and extended their lifespan by more than 4 weeks. However, it only conferred protection for $\mathrm{SOD} 1^{\mathrm{G} 93 \mathrm{~A}}$ - expressing mice by passive immunization, but not by active immunization (Urushitani et al. 2007). Different studies for developing a vaccine using either wild-type SOD1 or disease-related variants of SOD1 showed extension in lifespan and delay in disease progression (Takeuchi et al. 2010; Zhao et al. 2019). Yet, no clinical trials have been conducted for SOD1 immunization.

Protein stabilizers can be described as other proteins, peptides or small molecules that bind to a protein and prevent it from unfolding or aggregation. For instance, phthalocyanine tetrasulfonate (PcTs) can interact with the N-terminal region of $\alpha$-syn, leading to its stabilization through salt bridges and $\pi-\pi$ stacking interactions (Bisi et al. 2021; Lee et al. 2004). Importantly, PcTs can reduce cell death, fibril formation and amyloidosis induced by wild-type or mutant $\alpha$-syn (Fonseca-Ornelas et al. 2014; Lamberto et al. 2009; Lee et al. 2004). Although PcTs also appear to prevent the formation of aggregates from $\operatorname{PrP}, \mathrm{A} \beta$ and tau, it has not been investigated in clinical trials (Valiente-Gabioud et al. 2016). Tafamidis meglumine is a successful protein stabilizer that has been translated into a drug for disease intervention. Particularly, it was developed as a stabilizer for transthyretin (TTR), a serum transport protein. Under physiological conditions, TTR transports thyroid hormone T4 and retinol bound to retinol-binding protein as a tetramer complex. Certain mutations destabilize TTR tetramers and leads to its amyloidogenesis, which can cause rare diseases such as amyloid cardiomyopathy, senile systemic amyloidosis and amyloid polyneuropathy (Ruberg and Berk 2012). Tafamidis meglumine prevents TTR tetramer dissociation and the subsequent amyloidogenesis (Connelly et al. 2010). After successfully passing phase II and III of clinical trials, it was approved by FDA for treatment of TTR amyloidosis.

Regarding nanoparticles, this approach has several advantages over small molecules such as their ability to pass through blood-brain barrier (BBB) as well as their flexibility in size, charge and release rate of their cargo (Mudshinge et al. 2011; Patra et al. 2018). Many nanoparticles with different loads have been investigated for modifying distinct disease-related changes, such as mitochondrial dysfunction, inflammation and excitotoxicity, but here we will focus on nanoparticles and nanobodies targeting protein aggregation (Baskin et al. 2021; Mushtaq et al. 2015; Wang et al. 2020a,b). An example is epigallocatechin gallate (ECGC), a polyphenol which reduces the formation of $\alpha$-syn aggregates in cell-free environments, in vitro cultured neurons and animal models (Bieschke et al. 2010; Caruana et al. 2011; Kurnik et al. 2018; Xu et al. 2017). However, ECGC fell short of a successful clinical trial because its high hepatotoxicity and inefficacy in patients with multiple system atrophy (NCT02008721) (Levin et al. 2019). This could be partly attributed to poor blood-brain barrier penetration of ECGC, and inefficient uptake by dopaminergic neurons (Baskin et al. 2021). Li et al. addressed this issue using self-assembled B6 nanoparticles, which are peptides with a high affinity for transferrin receptor, coated with ECGC and mazindol, a drug with high affinity for dopamine transporter. Nanoparticle-delivered ECGC successfully accumulated in substantia nigra, and improved behavioral deficits and biomarkers in a mouse model of PD when compared with free ECGC ( $\mathrm{Li}$ et al. 2018). In addition to PD, nanoparticles were also investigated as a potential approach to modify disease-related protein aggregation in AD. In a recent study, Zhang and colleagues described IS@NP/KH, a bifunctional nanoparticle made of chitosan which is coated with both an $\mathrm{A} \beta$ oligomer-binding peptide and a brain-targeting peptide. Nasal administration of IS @NP/KH to APP/PS1 mice, which express both mutant APP and presenilin, attenuates cognitive decline, improved motor function and decreased amyloid plaques in the brain (Zhang et al. 2021c). In addition to multiple system atrophy, ECGC has also been investigated as a treatment for different aggregation pathologies. A phase II trial using ECGC for treating light-chain amyloidosis failed to demonstrate the efficacy of ECGC on improving the prognosis of the disease (Meshitsuka et al. 2017). Furthermore, two different phase II trials using ECGC for HD (NCT01357681) and AD (NCT00951834) have been completed, but their results are yet to be published.

Among small molecules, curcumin is a potential treatment to ameliorate protein aggregation. Curcumin is a natural phenol which can prevent aggregation of tau, $A \beta$ and $\alpha$-syn in cell-free conditions, both in vitro and in vivo (Pandey et al. 2008; Rane et al. 2017; Sharma and Nehru 2018; Yang et al. 2005). Unfortunately, the preclinical success of curcumin did not warrant positive clinical outcomes. A phase II study on AD patients showed no clinical or biochemical improvements of subjects after 24 weeks of curcumin administration (NCT00099710) (Ringman et al. 2012). Although the potential effects of curcumin on other proteinopathies are yet to be explored in a clinical context, it presents a challenge due to its inadequate efficacy ensued from low bioavailability (Anand et al. 2007). Methylene blue (MB) and leucomethylene blue (LMTM) has been long known to inhibit the formation of tau and $\alpha$-syn aggregates. As such, these compounds can improve behavioral deficits in mice models of tau and $\alpha$-syn aggregation (Masuda et al. 2006; Melis et al. 2015; Schwab et al. 2018; Taniguchi et al. 2005; Wischik et al. 1996). A phase II study using MB for treating mild or moderate $\mathrm{AD}$ showed the potential of $\mathrm{MB}$ to improve cognitive function in $\mathrm{AD}$ patients after 24 weeks of treatment (NCT00515333) (Wischik et al. 2015). A phase III study demonstrated that LMTM can reduce brain atrophy in patients after 9 months of drug administration 
(NCT01689246) (Wilcock et al. 2018). As of August 2021, another phase III trial is being conducted to assess the safety and efficacy of LMTM on AD patients (NCT03446001).

Due to a lack of availability of compounds that can activate the proteasome machinery, interventions to modulate autophagy through small molecules are in more advanced phases. For instance, 5-hydroxytryptamine receptor 6 (5-HT6) antagonists have gained attention as potential candidates for AD treatment. Interestingly, 5-HT6 antagonists increase mTOR activity, and theoretically should suppress autophagy (Meffre et al. 2012). Phase II trials (NCT00348192; NCT00710684; NCT00708552) using a 5-HT6 antagonist, SB-742457, only showed slight improvements in cognition of AD patients (Maher-Edwards et al. 2010, 2015). Likewise, lithium could not induce changes in the concentration of cerebrospinal fluid (CSF)-derived biomarkers and did not improve cognitive functions of $\mathrm{AD}$ patients in a 10-week treatment regimen (ISRCTN72046462) (Hampel et al. 2009). However, a 2-year treatment with lithium of patients with amnestic mild cognitive impairment (NCT01055392) mitigated their cognitive decline and also modified AD-related CSF biomarkers (Forlenza et al. 2019). Nonetheless, autophagy induction for AD treatment is still a promising approach. In these lines, different clinical studies using rapamycin (NCT04629495; NCT04200911), trehalose (NCT04663854) and hydralazine (NCT04842552) are currently active with some of them still being in the recruitment stage.

Nilotinib, an inhibitor of tyrosine kinase Abelson (c-Abl), was tested as a disease-modifying compound due to its enhancing effects on autophagy through activation of the kinase AMPK (Hussain et al. 2019; Karim et al. 2020; Karuppagounder et al. 2014; Yu et al. 2013). Particularly, inhibition of c-Abl via Nilotinib may have beneficial effects on PD patients. Induction of c-Abl can lead to the phosphorylation and inhibition of parkin E3 ligase activity, resulting in the accumulation of Parkin Interacting Substrate (PARIS) (Shin et al. 2011). The toxic increase of PARIS subsequently leads to mitochondrial dysfunction and loss of dopaminergic neurons (Shin et al. 2011). An early phase I trial of Nilotinib (NCT02281474) with 12 patients presented favorable but transient effects on PD patients. In this trial, patients were treated with either $150 \mathrm{mg}$ or $300 \mathrm{mg}$ of Nilotinib daily for 24 weeks. Whereas cognitive and motor functions improved transiently, they deteriorated again for both groups once the treatment was discontinued. In addition, the treatment group had serious adverse events such as urinary tract infection, pneumonia, myocardial infarct and psychotic symptoms which required further studies to clarify the potential therapeutic effects of Nilotinib (Pagan et al. 2016). A phase II trial with 76 participants (NCT03205488) revealed that Nilotinib did not provide any symptomatic benefits to PD patients. Furthermore, they confirmed that the penetrance of the drug in the CSF was low and that the levels of dopamine metabolites were unchanged (Simuni et al. 2021).

The medication Ambroxol is also a potential therapeutic approach for PD. Since Ambroxol has mucolytic activity, it is typically used as a pharmacological chaperone for airway diseases (Su et al. 2004). Interestingly, Ambroxol indirectly enhances autophagy by raising the levels of GCase which in turn decreases the levels of $\alpha$-syn. Treatment with Ambroxol results in increased LC3-II levels and lysosomal content (Choi et al. 2018; Magalhaes et al. 2018; Moors et al. 2017). A phase II trial on a small cohort of 17 PD patients demonstrated that Ambroxol treatment for 6 months improved their cognitive functions. Although the results are promising, this was a non-randomized, non-controlled trial which requires further investigation (Mullin et al. 2020). Two additional studies aiming to elucidate the effects of Ambroxol on PD pathology are in the recruitment stage (NCT02914366; NCT04388969).

To enhance protein clearance mechanisms in ALS, Chen and colleagues recently used Tamoxifen in a phase II critical trial (NCT02166944) (Chen et al. 2020). Tamoxifen is an anti-cancer drug that binds to estrogen receptor and inhibits cancer cell growth (Goodsell 2002; Shiau et al. 1998). Tamoxifen can also upregulate autophagy through both mTOR-dependent and -independent pathways (Cho et al. 2012; Kaverina et al. 2018; Torres-López et al. 2019). In their randomized double-blind trial, Chen et al. could only detect modest and transient effects of Tamoxifen treatment for 12 months. The decline in score of functional scale for ALS (ALSFRS-R) was slower in Tamoxifen-treated group for the first 6 months, but after 12 months the ALSFRS-R scores were identical between placebo and Tamoxifen-treated groups (Chen et al. 2020). Mandrioli and colleagues are currently recruiting patients with sporadic ALS for a phase II clinical trial (NCT03693781) using Colchicine, an anti-inflammatory drug. Besides its anti-inflammatory effects, Colchicine increases the mRNA and protein levels of the heat shock protein B8 (HSPB8). HSPB8 is a component of the chaperone-assisted selective autophagy machinery that promotes the removal of ALS-related variants of SOD1 and TDP-43 as well as aggregation-prone dipeptides derived from mutant C9orf72 (Crippa et al. 2016; Cristofani et al. 2017, 2018). Similar to other neurodegenerative diseases, the activation of inflammasome complexes in microglia and astrocytes in response to protein aggregation causes neuroinflammation that contributes to the neurodegeneration characteristic of ALS (Cadwell 2016; Mandrioli et al. 2019; Zhao et al. 2015). Since autophagy can downregulate the inflammasome activity triggered by aggregation of disease-related proteins, compounds such as Colchicine that target both neuroinflammation and autophagy are a promising approach for ALS treatment (Cadwell 2016; 
Mandrioli et al. 2019; Zhao et al. 2015). Another phase II study (NCT03359538) started in 2017 is assessing the effects of rapamycin-induced autophagy on ALS patients. Recently, this clinical trial completed primary data collection. However, the results are not yet publicly available.

Clinical data using molecules targeting UPS as a treatment for proteinopathies are much more limited. As mentioned above, IU1, an inhibitor of DUB activity of USP14, was reported to increase proteasomal degradation of several disease-related proteins (Lee et al. 2010). However, there are no clinical trials investigating the efficacy of IU1 for neurodegenerative diseases. On the other hand, a proteasomal enhancer sulforaphane is in early clinical phases. Notably, sulforaphane enhances the three proteolytic activities of the proteasome, i.e., chymotrypsin-like, caspase-like and trypsin-like activities in the brains of mice (Liu et al. 2014). Currently, a clinical trial conducted by Zhejiang University is in the recruitment phase for AD patients to assess the therapeutic potency of sulforaphane (NCT04213391).

\section{Conclusions}

Proteinopathies are complex, multifaceted diseases that lead to or exacerbate neurodegenerative and immune system disorders as well as cancer (Grimaldi et al. 2018; Kanapathipillai 2018; Kumar et al. 2016; Yang-Hartwich et al. 2015a,b). Although the clearance of damaged and aggregated proteins proves to ameliorate neurodegenerative disease-related changes in cellular and organismal models, a complete understanding of their regulatory mechanisms and how they can be modified to prevent disease is far from understood. Having discrete models of such proteinopathies is a first step, but researchers bear in mind that a single model cannot encapsulate all the aspects of a disease. This is evident by distinct models of neurodegenerative diseases responding differently to the same drug regimens (Fornai et al. 2008; Kim et al. 2011; Pizzasegola et al. 2009; Yong et al. 2011). Further combined endeavors from basic science and translational approaches will continue elucidating potential mechanisms for treating proteinopathies.

Acknowledgements This work was supported by the Deutsche Forschungsgemeinschaft (DFG) (VI742/4-1 and Germany's Excellence Strategy-CECAD, EXC 2030-390661388). The figures in the manuscript were generated using BioRender.com. Figure 3 is adapted from “Three Main Types of Autophagy”, by BioRender.com (2021).

Funding Open Access funding enabled and organized by Projekt DEAL.

\section{Declarations}

Conflict of interest The authors declare no conflict of interest.

Open Access This article is licensed under a Creative Commons Attribution 4.0 International License, which permits use, sharing, adaptation, distribution and reproduction in any medium or format, as long as you give appropriate credit to the original author(s) and the source, provide a link to the Creative Commons licence, and indicate if changes were made. The images or other third party material in this article are included in the article's Creative Commons licence, unless indicated otherwise in a credit line to the material. If material is not included in the article's Creative Commons licence and your intended use is not permitted by statutory regulation or exceeds the permitted use, you will need to obtain permission directly from the copyright holder. To view a copy of this licence, visit http://creativecommons.org/licenses/by/4.0/.

\section{References}

Alexopoulou Z, Lang J, Perrett RM, Elschami M, Hurry MED, Kim HT, Mazaraki D, Szabo A, Kessler BM, Goldberg AL, Ansorge O, Fulga TA, Tofaris GK (2016) Deubiquitinase Usp8 regulates $\alpha$-synuclein clearance and modifies its toxicity in Lewy body disease. PNAS 113:E4688-E4697. https://doi.org/10.1073/pnas. 1523597113

Almond JB, Cohen GM (2002) The proteasome: a novel target for cancer chemotherapy. Leukemia 16:433-443. https://doi.org/10. 1038/sj.leu.2402417

Alvarez-Erviti L, Rodriguez-Oroz MC, Cooper JM, Caballero C, Ferrer I, Obeso JA, Schapira AHV (2010) Chaperone-mediated autophagy markers in parkinson disease brains. Arch Neurol 67:1464-1472. https://doi.org/10.1001/archneurol.2010.198

Amer-Sarsour F, Kordonsky A, Berdichevsky Y, Prag G, Ashkenazi A (2021) Deubiquitylating enzymes in neuronal health and disease. Cell Death Dis 12:1-11. https://doi.org/10.1038/ s41419-020-03361-5

Anand P, Kunnumakkara AB, Newman RA, Aggarwal BB (2007) Bioavailability of curcumin: problems and promises. Mol Pharm 4:807-818. https://doi.org/10.1021/mp700113r

Arai T, Hasegawa M, Akiyama H, Ikeda K, Nonaka T, Mori H, Mann D, Tsuchiya K, Yoshida M, Hashizume Y, Oda T (2006) TDP-43 is a component of ubiquitin-positive tau-negative inclusions in frontotemporal lobar degeneration and amyotrophic lateral sclerosis. Biochem Biophys Res Commun 351:602-611. https://doi. org/10.1016/j.bbrc.2006.10.093

Arima K, Uéda K, Sunohara N, Hirai S, Izumiyama Y, TonozukaUehara H, Kawai M (1998) Immunoelectron-microscopic demonstration of NACP/ $\alpha$-synuclein-epitopes on the filamentous component of Lewy bodies in Parkinson's disease and in dementia with Lewy bodies. Brain Res 808:93-100. https://doi.org/10. 1016/S0006-8993(98)00734-3

Arlt A, Bauer I, Schafmayer C, Tepel J, Müerköster SS, Brosch M, Röder C, Kalthoff H, Hampe J, Moyer MP, Fölsch UR, Schäfer $\mathrm{H}$ (2009) Increased proteasome subunit protein expression and proteasome activity in colon cancer relate to an enhanced activation of nuclear factor E2-related factor 2 (Nrf2). Oncogene 28:3983-3996. https://doi.org/10.1038/onc.2009.264

Arosio P, Vendruscolo M, Dobson CM, Knowles TPJ (2014) Chemical kinetics for drug discovery to combat protein aggregation diseases. Trends Pharmacol Sci 35:127-135. https://doi.org/10. 1016/j.tips.2013.12.005 
Ash PEA, Bieniek KF, Gendron TF, Caulfield T, Lin W-L, DejesusHernandez M, van Blitterswijk MM, Jansen-West K, Paul JW, Rademakers R, Boylan KB, Dickson DW, Petrucelli L (2013) Unconventional translation of C9ORF72 GGGGCC expansion generates insoluble polypeptides specific to c9FTD/ALS. Neuron 77:639-646. https://doi.org/10.1016/j.neuron.2013.02.004

Ashkenazi A, Bento CF, Ricketts T, Vicinanza M, Siddiqi F, Pavel M, Squitieri F, Hardenberg MC, Imarisio S, Menzies FM, Rubinsztein DC (2017) Polyglutamine tracts regulate beclin 1-dependent autophagy. Nature 545:108-111. https://doi.org/10.1038/natur e22078

Bae E-J, Yang NY, Lee C, Lee H-J, Kim S, Sardi SP, Lee S-J (2015) Loss of glucocerebrosidase 1 activity causes lysosomal dysfunction and $\alpha$-synuclein aggregation. Exp Mol Med 47:e153-e153. https://doi.org/10.1038/emm.2014.128

Bai X, Wey MC-Y, Fernandez E, Hart MJ, Gelfond J, Bokov AF, Rani S, Strong R (2015) Rapamycin improves motor function, reduces 4-hydroxynonenal adducted protein in brain, and attenuates synaptic injury in a mouse model of synucleinopathy. Pathobiol Aging Age-Relat Dis 5:28743. https://doi.org/10.3402/pba.v5. 28743

Ballinger CA, Connell P, Wu Y, Hu Z, Thompson LJ, Yin L-Y, Patterson C (1999) Identification of CHIP, a Novel tetratricopeptide repeat-containing protein that interacts with heat shock proteins and negatively regulates chaperone functions. Mol Cell Biol 19:4535-4545

Bandyopadhyay U, Kaushik S, Varticovski L, Cuervo AM (2008) The chaperone-mediated autophagy receptor organizes in dynamic protein complexes at the lysosomal membrane. Mol Cell Biol 28:5747-5763. https://doi.org/10.1128/MCB.02070-07

Bard F, Barbour R, Cannon C, Carretto R, Fox M, Games D, Guido T, Hoenow K, Hu K, Johnson-Wood K, Khan K, Kholodenko D, Lee C, Lee M, Motter R, Nguyen M, Reed A, Schenk D, Tang P, Vasquez N, Seubert P, Yednock T (2003) Epitope and isotype specificities of antibodies to beta -amyloid peptide for protection against Alzheimer's disease-like neuropathology. Proc Natl Acad Sci USA 100:2023-2028. https://doi.org/10.1073/pnas. 0436286100

Baroja-Mazo A, Revilla-Nuin B, Ramírez P, Pons JA (2016) Immunosuppressive potency of mechanistic target of rapamycin inhibitors in solid-organ transplantation. World J Transplant 6:183-192. https://doi.org/10.5500/wjt.v6.i1.183

Bartoletti M et al (2019) Phenotypic suppression of ALS/FTD-associated neurodegeneration highlights mechanisms of dysfunction. J Neurosci 39:8217-8224

Baskin J, Jeon JE, Lewis SJG (2021) Nanoparticles for drug delivery in Parkinson's disease. J Neurol 268:1981-1994. https://doi.org/ 10.1007/s00415-020-10291-x

Bax M, McKenna J, Do-Ha D, Stevens CH, Higginbottom S, Balez R, Cabral-da-Silva MEC, Farrawell NE, Engel M, Poronnik P, Yerbury JJ, Saunders DN, Ooi L (2019) The ubiquitin proteasome system is a key regulator of pluripotent stem cell survival and motor neuron differentiation. Cells 8:581. https://doi.org/10. 3390/cells8060581

Beasley SA, Hristova VA, Shaw GS (2007) Structure of the Parkin inbetween-ring domain provides insights for E3-ligase dysfunction in autosomal recessive Parkinson's disease. Proc Natl Acad Sci USA 104:3095-3100. https://doi.org/10.1073/pnas.0610548104

Beason-Held LL, Goh JO, An Y, Kraut MA, O’Brien RJ, Ferrucci L, Resnick SM (2013) Changes in brain function occur years before the onset of cognitive impairment. J Neurosci 33:18008-18014. https://doi.org/10.1523/JNEUROSCI.1402-13.2013

Belch A, Kouroukis CT, Crump M, Sehn L, Gascoyne RD, Klasa R, Powers J, Wright J, Eisenhauer EA (2007) A phase II study of bortezomib in mantle cell lymphoma: the national cancer institute of canada clinical trials group trial IND.150. Ann Oncol 18:116-121. https://doi.org/10.1093/annonc/mdl316

Ben-Sahra I, Manning BD (2017) mTORC1 signaling and the metabolic control of cell growth. Curr Opin Cell Biol Cell Regul 45:72-82. https://doi.org/10.1016/j.ceb.2017.02.012

Bentmann E, Haass C, Dormann D (2013) Stress granules in neurodegeneration-lessons learnt from TAR DNA binding protein of 43 $\mathrm{kDa}$ and fused in sarcoma. FEBS J 280:4348-4370. https://doi. org/10.1111/febs. 12287

Bhattacharya A, Bokov A, Muller FL, Jernigan AL, Maslin K, Diaz V, Richardson A, Van Remmen H (2012) Dietary restriction but not rapamycin extends disease onset and survival of the H46R/H48Q mouse model of ALS. Neurobiol Aging 33:1829-1832. https:// doi.org/10.1016/j.neurobiolaging.2011.06.002

Bieschke J, Russ J, Friedrich RP, Ehrnhoefer DE, Wobst H, Neugebauer K, Wanker EE (2010) EGCG remodels mature alpha-synuclein and amyloid-beta fibrils and reduces cellular toxicity. Proc Natl Acad Sci USA 107:7710-7715. https://doi.org/10.1073/pnas. 0910723107

Bisi N, Feni L, Peqini K, Pérez-Peña H, Ongeri S, Pieraccini S, Pellegrino $S$ (2021) $\alpha$-synuclein: an all-inclusive trip around its structure, influencing factors and applied techniques. Front Chem 9:457. https://doi.org/10.3389/fchem.2021.666585

Bjørkøy G, Lamark T, Brech A, Outzen H, Perander M, Overvatn A, Stenmark H, Johansen T (2005) p62/SQSTM1 forms protein aggregates degraded by autophagy and has a protective effect on huntingtin-induced cell death. J Cell Biol 171:603-614. https://doi.org/10.1083/jcb.200507002

Blommaart EFC, Luiken JJFP, Blommaart PJE, van Woerkom GM, Meijer AJ (1995) Phosphorylation of ribosomal protein S6 Is inhibitory for autophagy in isolated rat hepatocytes $(*)$. J Biol Chem 270:2320-2326. https://doi.org/10.1074/jbc.270.5.2320

Bourdenx M, Daniel J, Genin E, Soria FN, Blanchard-Desce M, Bezard E, Dehay B (2016) Nanoparticles restore lysosomal acidification defects: implications for Parkinson and other lysosomal-related diseases. Autophagy 12:472-483. https:// doi.org/10.1080/15548627.2015.1136769

Brignull HR, Moore FE, Tang SJ, Morimoto RI (2006) Polyglutamine proteins at the pathogenic threshold display neuronspecific aggregation in a pan-neuronal caenorhabditis elegans model. J Neurosci 26:7597-7606. https://doi.org/10.1523/ JNEUROSCI.0990-06.2006

Brockman SM, Bodas M, Silverberg D, Sharma A, Vij N (2017) Dendrimer-based selective autophagy-induction rescues $\Delta$ F508-CFTR and inhibits pseudomonas aeruginosa infection in cystic fibrosis. PLoS ONE 12:e0184793. https://doi.org/10. 1371/journal.pone.0184793

Budanov AV, Karin M (2008) The p53-regulated sestrin gene products inhibit mTOR signaling. Cell 134:451-460. https://doi. org/10.1016/j.cell.2008.06.028

Caccamo A, Oddo S, Tran LX, LaFerla FM (2007) Lithium reduces tau phosphorylation but not $A \beta$ or working memory deficits in a transgenic model with both plaques and tangles. Am J Pathol 170:1669-1675. https://doi.org/10.2353/ajpath.2007.061178

Cadwell K (2016) Crosstalk between autophagy and inflammatory signalling pathways: balancing defence and homeostasis. Nat Rev Immunol 16:661-675. https://doi.org/10.1038/nri.2016. 100

Capili AD, Edghill EL, Wu K, Borden KLB (2004) Structure of the C-terminal RING finger from a RING-IBR-RING/TRIAD motif reveals a novel zinc-binding domain distinct from a RING. J Mol Biol 340:1117-1129. https://doi.org/10.1016/j.jmb.2004.05.035

Cárdenas C, Miller RA, Smith I, Bui T, Molgó J, Müller M, Vais H, Cheung K-H, Yang J, Parker I, Thompson CB, Birnbaum MJ, Hallows KR, Foskett JK (2010) Essential regulation of cell 
bioenergetics by constitutive InsP3 receptor $\mathrm{Ca} 2+$ transfer to mitochondria. Cell 142:270-283. https://doi.org/10.1016/j.cell. 2010.06.007

Carson DA, Lois A (1995) Cancer progression and p53. Lancet 346:1009-1011. https://doi.org/10.1016/s0140-6736(95)91693-8

Cartier AE, Djakovic SN, Salehi A, Wilson SM, Masliah E, Patrick GN (2009) Regulation of synaptic structure by ubiquitin C-terminal hydrolase L1. J Neurosci 29:7857-7868. https://doi.org/10.1523/ JNEUROSCI.1817-09.2009

Caruana M, Högen T, Levin J, Hillmer A, Giese A, Vassallo N (2011) Inhibition and disaggregation of $\alpha$-synuclein oligomers by natural polyphenolic compounds. FEBS Lett 585:1113-1120. https:// doi.org/10.1016/j.febslet.2011.03.046

Chakraborty J, von Stockum S, Marchesan E, Caicci F, Ferrari V, Rakovic A, Klein C, Antonini A, Bubacco L, Ziviani E (2018) USP14 inhibition corrects an in vivo model of impaired mitophagy. EMBO Mol Med. https://doi.org/10.15252/emmm.201809014

Chana-Cuevas P, Salles-Gándara P, Rojas-Fernandez A, SalinasRebolledo C, Milan-Sole A (2020) The potential role of SARSCOV-2 in the pathogenesis of Parkinson's disease. Front Neurol. https://doi.org/10.3389/fneur.2020.01044

Chauhan D, Catley L, Li G, Podar K, Hideshima T, Velankar M, Mitsiades C, Mitsiades N, Yasui H, Letai A, Ovaa H, Berkers C, Nicholson B, Chao T-H, Neuteboom STC, Richardson P, Palladino MA, Anderson KC (2005) A novel orally active proteasome inhibitor induces apoptosis in multiple myeloma cells with mechanisms distinct from Bortezomib. Cancer Cell 8:407-419. https://doi.org/10.1016/j.ccr.2005.10.013

Chen L, Madura K (2005) Increased proteasome activity, ubiquitinconjugating enzymes, and eEF1A translation factor detected in breast cancer tissue. Cancer Res 65:5599-5606. https://doi.org/ 10.1158/0008-5472.CAN-05-0201

Chen CI, Kouroukis CT, White D, Voralia M, Stadtmauer E, Stewart AK, Wright JJ, Powers J, Walsh W, Eisenhauer E, National Cancer Institute of Canada Clinical Trials Group (2007) Bortezomib is active in patients with untreated or relapsed Waldenstrom's macroglobulinemia: a phase II study of the National Cancer Institute of Canada Clinical Trials Group. J Clin Oncol 25:15701575. https://doi.org/10.1200/JCO.2006.07.8659

Chen J-J, Lin F, Qin Z-H (2008) The roles of the proteasome pathway in signal transduction and neurodegenerative diseases. Neurosci Bull 24:183. https://doi.org/10.1007/s12264-008-0183-6

Chen Z, Chen J, Keshamouni VG, Kanapathipillai M (2017) Polyarginine and its analogues inhibit p53 mutant aggregation and cancer cell proliferation in vitro. Biochem Biophys Res Commun 489:130-134. https://doi.org/10.1016/j.bbrc.2017.05.111

Chen L, Zhu G, Johns EM, Yang X (2018a) TRIM11 activates the proteasome and promotes overall protein degradation by regulating USP14. Nat Commun 9:1223. https://doi.org/10.1038/ s41467-018-03499-Z

Chen T, Huang B, Shi X, Gao L, Huang C (2018b) Mutant UBQL$\mathrm{N} 2 \mathrm{P} 497 \mathrm{H}$ in motor neurons leads to ALS-like phenotypes and defective autophagy in rats. Acta Neuropathol Commun 6:122. https://doi.org/10.1186/s40478-018-0627-9

Chen P-C, Hsieh Y-C, Huang C-C, Hu C-J (2020) Tamoxifen for amyotrophic lateral sclerosis: a randomized double-blind clinical trial. Medicine 99:e20423. https://doi.org/10.1097/MD.0000000000 020423

Chernova TA, Romanyuk AV, Karpova TS, Shanks JR, Ali M, Moffatt N, Howie RL, O'Dell A, McNally JG, Liebman SW, Chernoff YO, Wilkinson KD (2011) Prion induction by the short-lived, stress-induced protein Lsb2 is regulated by ubiquitination and association with the actin cytoskeleton. Mol Cell 43:242-252. https://doi.org/10.1016/j.molcel.2011.07.001

Chiang HL, Terlecky SR, Plant CP, Dice JF (1989) A role for a 70-kilodalton heat shock protein in lysosomal degradation of intracellular proteins. Science 246:382-385. https://doi.org/10. 1126/science. 2799391

Chiu H-W, Yeh Y-L, Ho S-Y, Wu Y-H, Wang B-J, Huang W-J, Ho Y-S, Wang Y-J, Chen L-C, Tu S-H (2019) A new histone deacetylase inhibitor enhances radiation sensitivity through the induction of misfolded protein aggregation and autophagy in triple-negative breast cancer. Cancers (basel). https://doi.org/10.3390/cance rs 11111703

Cho KS, Yoon YH, Choi JA, Lee S-J, Koh J-Y (2012) Induction of autophagy and cell death by tamoxifen in cultured retinal pigment epithelial and photoreceptor cells. Invest Ophthalmol vis Sci 53:5344-5353. https://doi.org/10.1167/iovs.12-9827

Choi J, Baek K-H (2018) Cellular functions of stem cell factors mediated by the ubiquitin-proteasome system. Cell Mol Life Sci 75:1947-1957. https://doi.org/10.1007/s00018-018-2770-7

Choi SW, Gu Y, Peters RS, Salgame P, Ellner JJ, Timmins GS, Deretic V (2018) Ambroxol induces autophagy and potentiates rifampin antimycobacterial activity. Antimicrob Agents Chemother. https://doi.org/10.1128/AAC.01019-18

Chollat-Namy M, Ben Safta-Saadoun T, Haferssas D, Meurice G, Chouaib S, Thiery J (2019) The pharmalogical reactivation of p53 function improves breast tumor cell lysis by granzyme B and NK cells through induction of autophagy. Cell Death Dis 10:695. https://doi.org/10.1038/s41419-019-1950-1

Chou P-Y, Lin S-R, Lee M-H, Schultz L, Sze C-I, Chang N-S (2019) A p53/TIAF1/WWOX triad exerts cancer suppression but may cause brain protein aggregation due to p53/WWOX functional antagonism. Cell Commun Signal 17:76. https://doi.org/10.1186/ s12964-019-0382-y

Clague MJ, Urbé S, Komander D (2019) Breaking the chains: deubiquitylating enzyme specificity begets function. Nat Rev Mol Cell Biol 20:338-352. https://doi.org/10.1038/s41580-019-0099-1

Clark EH, Vázquez de la Torre A, Hoshikawa T, Briston T (2020) Targeting mitophagy in Parkinson's disease. J Biol Chem 296:100209. https://doi.org/10.1074/jbc.REV120.014294

Cohen E, Dillin A (2008) The insulin paradox: aging, proteotoxicity and neurodegeneration. Nat Rev Neurosci 9:759-767

Connelly S, Choi S, Johnson SM, Kelly JW, Wilson IA (2010) Structure-based design of kinetic stabilizers that ameliorate the transthyretin amyloidoses. Curr Opin Struct Biol 20:54-62. https:// doi.org/10.1016/j.sbi.2009.12.009

Cooper-Knock J, Hewitt C, Highley JR, Brockington A, Milano A, Man S, Martindale J, Hartley J, Walsh T, Gelsthorpe C, Baxter L, Forster G, Fox M, Bury J, Mok K, McDermott CJ, Traynor BJ, Kirby J, Wharton SB, Ince PG, Hardy J, Shaw PJ (2012) Clinico-pathological features in amyotrophic lateral sclerosis with expansions in C9ORF72. Brain 135:751-764. https://doi. org/10.1093/brain/awr365

Corti O, Blomgren K, Poletti A, Beart PM (2020) Autophagy in neurodegeneration: New insights underpinning therapy for neurological diseases. J Neurochem 154:354-371. https://doi.org/10. 1111 jnc. 15002

Crawford LJ, Walker B, Irvine AE (2011) Proteasome inhibitors in cancer therapy. J Cell Commun Signal 5:101-110. https://doi. org/10.1007/s12079-011-0121-7

Crippa V, Cicardi ME, Ramesh N, Seguin SJ, Ganassi M, Bigi I, Diacci C, Zelotti E, Baratashvili M, Gregory JM, Dobson CM, Cereda C, Pandey UB, Poletti A, Carra S (2016) The chaperone HSPB8 reduces the accumulation of truncated TDP-43 species in cells and protects against TDP-43-mediated toxicity. Hum Mol Genet 25:3908-3924. https://doi.org/10.1093/hmg/ddw232

Cristofani R, Crippa V, Rusmini P, Cicardi ME, Meroni M, Licata NV, Sala G, Giorgetti E, Grunseich C, Galbiati M, Piccolella M, Messi E, Ferrarese C, Carra S, Poletti A (2017) Inhibition of retrograde transport modulates misfolded protein accumulation and 
clearance in motoneuron diseases. Autophagy 13:1280-1303. https://doi.org/10.1080/15548627.2017.1308985

Cristofani R, Crippa V, Vezzoli G, Rusmini P, Galbiati M, Cicardi ME, Meroni M, Ferrari V, Tedesco B, Piccolella M, Messi E, Carra S, Poletti A (2018) The small heat shock protein B8 (HSPB8) efficiently removes aggregating species of dipeptides produced in C9ORF72-related neurodegenerative diseases. Cell Stress Chaperones 23:1-12. https://doi.org/10.1007/s12192-017-0806-9

Cruts M, Theuns J, Van Broeckhoven C (2012) Locus-specific mutation databases for neurodegenerative brain diseases. Hum Mutat 33:1340-1344. https://doi.org/10.1002/humu.22117

Dang F, Nie L, Wei W (2021) Ubiquitin signaling in cell cycle control and tumorigenesis. Cell Death Differ 28:427-438. https://doi. org/10.1038/s41418-020-00648-0

De Ferrari GV, Chacón MA, Barría MI, Garrido JL, Godoy JA, Olivares $\mathrm{G}$, Reyes AE, Alvarez A, Bronfman M, Inestrosa NC (2003) Activation of Wnt signaling rescues neurodegeneration and behavioral impairments induced by $\beta$-amyloid fibrils. Mol Psychiatry 8:195-208. https://doi.org/10.1038/sj.mp.4001208

Decuypere J-P, Monaco G, Bultynck G, Missiaen L, De Smedt H, Parys JB (2011) The IP3 receptor-mitochondria connection in apoptosis and autophagy. Biochimica Et Biophysica Acta (BBA) - Mol Cell Res 1813:1003-1013. https://doi.org/10.1016/j.bbamcr. 2010.11.023

DeJesus-Hernandez M, Mackenzie IR, Boeve BF, Boxer AL, Baker M, Rutherford NJ, Nicholson AM, Finch NA, Flynn H, Adamson J, Kouri N, Wojtas A, Sengdy P, Hsiung G-YR, Karydas A, Seeley WW, Josephs KA, Coppola G, Geschwind DH, Wszolek ZK, Feldman H, Knopman DS, Petersen RC, Miller BL, Dickson DW, Boylan KB, Graff-Radford NR, Rademakers R (2011) Expanded GGGGCC hexanucleotide repeat in noncoding region of C9ORF72 causes chromosome 9p-linked FTD and ALS. Neuron 72:245-256. https://doi.org/10.1016/j.neuron.2011.09.011

Delic J, Masdehors P, Omura S, Cosset JM, Dumont J, Binet JL, Magdelénat H (1998) The proteasome inhibitor lactacystin induces apoptosis and sensitizes chemo- and radioresistant human chronic lymphocytic leukaemia lymphocytes to TNFalpha-initiated apoptosis. Br J Cancer 77:1103-1107. https:// doi.org/10.1038/bjc.1998.183

Deng HX, Zhai H, Bigio EH, Yan J, Fecto F, Ajroud K, Mishra M, Ajroud-Driss S, Heller S, Sufit R, Siddique N (2010) FUS-immunoreactive inclusions are a common feature in sporadic and nonSOD1 familial amyotrophic lateral sclerosis. Ann Neurol. https:// doi.org/10.1002/ana.22051

Deng L, Meng T, Chen L, Wei W, Wang P (2020) The role of ubiquitination in tumorigenesis and targeted drug discovery. Sig Transduct Target Ther 5:1-28. https://doi.org/10.1038/ s41392-020-0107-0

Devoy A, Soane T, Welchman R, Mayer RJ (2005) The ubiquitin-proteasome system and cancer. Essays Biochem 41:187-203. https:// doi.org/10.1042/EB0410187

Dice JF (1988) Microinjected ribonuclease A as a probe for lysosomal pathways of intracellular protein degradation. J Protein Chem 7:115-127. https://doi.org/10.1007/BF01025241

Dickey CA, Yue M, Lin W-L, Dickson DW, Dunmore JH, Lee WC, Zehr C, West G, Cao S, Clark AMK, Caldwell GA, Caldwell KA, Eckman C, Patterson C, Hutton M, Petrucelli L (2006) Deletion of the ubiquitin ligase CHIP leads to the accumulation, but not the aggregation, of both endogenous phospho- and caspase3-cleaved tau species. J Neurosci 26:6985-6996. https://doi.org/ 10.1523/JNEUROSCI.0746-06.2006

Ding Y, Liu H, Cen M, Tao Y, Lai C, Tang Z (2021) Rapamycin ameliorates cognitive impairments and Alzheimer's disease-like pathology with restoring mitochondrial abnormality in the hippocampus of streptozotocin-induced diabetic mice. Neurochem Res 46:265-275. https://doi.org/10.1007/s11064-020-03160-6
Djajadikerta A, Keshri S, Pavel M, Prestil R, Ryan L, Rubinsztein DC (2020) Autophagy induction as a therapeutic strategy for neurodegenerative diseases. J Mol Biol 432:2799-2821. https:// doi.org/10.1016/j.jmb.2019.12.035

Dolatshahi M, Sabahi M, Aarabi MH (2021) Pathophysiological clues to how the emergent SARS-CoV-2 can potentially increase the susceptibility to neurodegeneration. Mol Neurobiol 58:23792394. https://doi.org/10.1007/s12035-020-02236-2

Du W, Mei Q (2013) Ubiquitin-proteasome system, a new anti-tumor target. Acta Pharmacol Sin 34:187-188. https://doi.org/10.1038/ aps.2012.192

Duda DM, Olszewski JL, Schuermann JP, Kurinov I, Miller DJ, Nourse A, Alpi AF, Schulman BA (2013) Structure of HHARI, a RINGIBR-RING ubiquitin ligase: autoinhibition of an Ariadne-family E3 and insights into ligation mechanism. Structure 21:10301041. https://doi.org/10.1016/j.str.2013.04.019

Dudkin L, Dilling MB, Cheshire PJ, Harwood FC, Hollingshead M, Arbuck SG, Travis R, Sausville EA, Houghton PJ (2001) Biochemical correlates of mTOR inhibition by the rapamycin ester CCI-779 and tumor growth inhibition. Clin Cancer Res $7: 1758-1764$

Dunn B, Stein P, Cavazzoni P (2021) Approval of aducanumab for Alzheimer disease - the FDA's perspective. JAMA Intern Med. https://doi.org/10.1001/jamainternmed.2021.4607

Durcan TM, Tang MY, Pérusse JR, Dashti EA, Aguileta MA, McLelland G-L, Gros P, Shaler TA, Faubert D, Coulombe B, Fon EA (2014) USP8 regulates mitophagy by removing K6-linked ubiquitin conjugates from parkin. EMBO J 33:2473-2491. https:// doi.org/10.15252/embj.201489729

Embi N, Rylatt DB, Cohen P (1980) Glycogen synthase kinase-3 from rabbit skeletal muscle. Separation from cyclic-AMPdependent protein kinase and phosphorylase kinase. Eur J Biochem 107:519-527

Fares MB, Jagannath S, Lashuel HA (2021) Reverse engineering Lewy bodies: how far have we come and how far can we go? Nat Rev Neurosci 22:111-131. https://doi.org/10.1038/ s41583-020-00416-6

Fatima A, Irmak D, Noormohammadi A, Rinschen MM, Das A, Leidecker O, Schindler C, Sánchez-Gaya V, Wagle P, Pokrzywa W, Hoppe T, Rada-Iglesias A, Vilchez D (2020) The ubiquitinconjugating enzyme UBE2K determines neurogenic potential through histone $\mathrm{H} 3$ in human embryonic stem cells. Commun Biol 3:262. https://doi.org/10.1038/s42003-020-0984-3

Fett ME, Pilsl A, Paquet D, van Bebber F, Haass C, Tatzelt J, Schmid B, Winklhofer KF (2010) Parkin Is protective against proteotoxic stress in a transgenic zebrafish model. PLoS ONE 5:e11783. https://doi.org/10.1371/journal.pone.0011783

Fisher RI, Bernstein SH, Kahl BS, Djulbegovic B, Robertson MJ, de Vos S, Epner E, Krishnan A, Leonard JP, Lonial S, Stadtmauer EA, O'Connor OA, Shi H, Boral AL, Goy A (2006) Multicenter phase II study of bortezomib in patients with relapsed or refractory mantle cell lymphoma. J Clin Oncol 24:4867-4874. https://doi.org/10.1200/jco.2006.07.9665

Fonseca-Ornelas L, Eisbach SE, Paulat M, Giller K, Fernández CO, Outeiro TF, Becker S, Zweckstetter M (2014) Small moleculemediated stabilization of vesicle-associated helical $\alpha$-synuclein inhibits pathogenic misfolding and aggregation. Nat Commun 5:5857. https://doi.org/10.1038/ncomms6857

Forlenza OV, Radanovic M, Talib LL, Gattaz WF (2019) Clinical and biological effects of long-term lithium treatment in older adults with amnestic mild cognitive impairment: randomised clinical trial. Br J Psychiatry 215:668-674. https://doi.org/10. 1192/bjp. 2019.76

Fornai F, Longone P, Cafaro L, Kastsiuchenka O, Ferrucci M, Manca ML, Lazzeri G, Spalloni A, Bellio N, Lenzi P, Modugno N, Siciliano G, Isidoro C, Murri L, Ruggieri S, Paparelli A (2008) 
Lithium delays progression of amyotrophic lateral sclerosis. Proc Natl Acad Sci USA 105:2052-2057. https://doi.org/10. 1073/pnas.0708022105

Fournier M, Vitte J, Garrigue J, Langui D, Dullin J-P, Saurini F, Hanoun N, Perez-Diaz F, Cornilleau F, Joubert C, ArdilaOsorio H, Traver S, Duchateau R, Goujet-Zalc C, Paleologou K, Lashuel HA, Haass C, Duyckaerts C, Cohen-Salmon C, Kahle PJ, Hamon M, Brice A, Corti O (2009) Parkin deficiency delays motor decline and disease manifestation in a mouse model of synucleinopathy. PLoS ONE 4:e6629. https://doi.org/ 10.1371/journal.pone.0006629

Frake RA, Ricketts T, Menzies FM, Rubinsztein DC (2015) Autophagy and neurodegeneration. J Clin Invest 125:65-74. https://doi.org/10.1172/JCI73944

Frankel A, Man S, Elliott P, Adams J, Kerbel RS (2000) Lack of multicellular drug resistance observed in human ovarian and prostate carcinoma treated with the proteasome inhibitor PS-341. Clin Cancer Res 6:3719-3728

Gavilán E, Sánchez-Aguayo I, Daza P, Ruano D (2013) GSK-3 $\beta$ signaling determines autophagy activation in the breast tumor cell line MCF7 and inclusion formation in the non-tumor cell line MCF10A in response to proteasome inhibition. Cell Death Dis 4:e572-e572. https://doi.org/10.1038/cddis.2013.95

Gerbino V, Kaunga E, Ye J, Canzio D, O'Keeffe S, Rudnick ND, Guarnieri P, Lutz CM, Maniatis T (2020) The loss of TBK1 kinase activity in motor neurons or in all cell types differentially impacts ALS disease progression in SOD1 Mice. Neuron 106:789-805.e5. https://doi.org/10.1016/j.neuron.2020.03.005

Giordana MT, Piccinini M, Grifoni S, De Marco G, Vercellino M, Magistrello M, Pellerino A, Buccinnà B, Lupino E, Rinaudo MT (2010) TDP-43 redistribution is an early event in sporadic amyotrophic lateral sclerosis. Brain Pathol 20:351-360. https:// doi.org/10.1111/j.1750-3639.2009.00284.x

Gladkova C, Maslen SL, Skehel JM, Komander D (2018) Mechanism of parkin activation by PINK1. Nature 559:410-414. https://doi. org/10.1038/s41586-018-0224-x

Goode A, Butler K, Long J, Cavey J, Scott D, Shaw B, Sollenberger J, Gell C, Johansen T, Oldham NJ, Searle MS, Layfield R (2016) Defective recognition of LC3B by mutant SQSTM1/p62 implicates impairment of autophagy as a pathogenic mechanism in ALS-FTLD. Autophagy 12:1094-1104. https://doi.org/10.1080/ 15548627.2016.1170257

Goodsell DS (2002) The molecular perspective: tamoxifen and the estrogen receptor. Stem Cells 20:267-268. https://doi.org/10. 1634/stemcells.20-3-267

Grimaldi A, Brighi C, Peruzzi G, Ragozzino D, Bonanni V, Limatola C, Ruocco G, Di Angelantonio S (2018) Inflammation, neurodegeneration and protein aggregation in the retina as ocular biomarkers for Alzheimer's disease in the 3xTg-AD mouse model. Cell Death Dis 9:1-10. https://doi.org/10.1038/s41419-018-0740-5

Gruber A, Hornburg D, Antonin M, Krahmer N, Collado J, Schaffer M, Zubaite G, Lüchtenborg C, Sachsenheimer T, Brügger B, Mann M, Baumeister W, Hartl FU, Hipp MS, Fernández-Busnadiego R (2018) Molecular and structural architecture of polyQ aggregates in yeast. PNAS 115:E3446-E3453. https://doi.org/10.1073/pnas. 1717978115

Grünewald A, Voges L, Rakovic A, Kasten M, Vandebona H, Hemmelmann C, Lohmann K, Orolicki S, Ramirez A, Schapira AHV, Pramstaller PP, Sue CM, Klein C (2010) Mutant parkin impairs mitochondrial function and morphology in human fibroblasts. PLoS ONE. https://doi.org/10.1371/journal.pone.0012962

Guo Y-Y, Lu Y, Zheng Y, Chen X-R, Dong J-L, Yuan R-R, Huang S-H, Yu H, Wang Y, Chen Z-Y, Su B (2017) Ubiquitin C-terminal hydrolase L1 (UCH-L1) promotes hippocampus-dependent memory via its deubiquitinating effect on TrkB. J Neurosci
37:5978-5995. https://doi.org/10.1523/JNEUROSCI.3148-16. 2017

Guo T, Nan Z, Miao C, Jin X, Yang W, Wang Z, Tu Y, Bao H, Lyu J, Zheng H, Deng Q, Guo P, Xi Y, Yang X, Ge W (2019) The autophagy-related gene Atg101 in Drosophila regulates both neuron and midgut homeostasis. J Biol Chem 294:5666-5676. https://doi.org/10.1074/jbc.RA118.006069

Hampel H, Ewers M, Bürger K, Annas P, Mörtberg A, Bogstedt A, Frölich L, Schröder J, Schönknecht P, Riepe MW, Kraft I, Gasser T, Leyhe T, Möller H-J, Kurz A, Basun H (2009) Lithium trial in Alzheimer's disease: a randomized, single-blind, placebo-controlled, multicenter 10-week study. J Clin Psychiatry 70:922-931

Han KH, Kwak M, Lee TH, Park M, Jeong I, Kim MJ, Jin J-O, Lee PC-W (2019) USP14 inhibition regulates tumorigenesis by inducing autophagy in lung cancer in vitro. Int J Mol Sci 20:5300. https://doi.org/10.3390/ijms20215300

Haque E, Kamil M, Irfan S, Sheikh S, Hasan A, Nazir A, Mir SS (2018) Blocking mutation independent p53 aggregation by emodin modulates autophagic cell death pathway in lung cancer. Int J Biochem Cell Biol 96:90-95. https://doi.org/10.1016/j.biocel. 2018.01.014

Hatakeyama S (2011) TRIM proteins and cancer. Nat Rev Cancer 11:792-804. https://doi.org/10.1038/nrc3139

Hatakeyama R, Virgilio CD (2019) TORC1 specifically inhibits microautophagy through ESCRT-0. Curr Genet 65:1243-1249. https:// doi.org/10.1007/s00294-019-00982-y

Hershko A, Ciechanover A (1998) The UBIQUITIN SYSTEM. Annu Rev Biochem 67:425-479. https://doi.org/10.1146/annurev.bioch em.67.1.425

Hideshima T, Richardson P, Chauhan D, Palombella VJ, Elliott PJ, Adams J, Anderson KC (2001) The proteasome inhibitor PS-341 inhibits growth, induces apoptosis, and overcomes drug resistance in human multiple myeloma cells. Cancer Res 61:3071-3076

Hipp MS, Kasturi P, Hartl FU (2019) The proteostasis network and its decline in ageing. Nat Rev Mol Cell Biol 20:421-435. https:// doi.org/10.1038/s41580-019-0101-y

Homma T, Ishibashi D, Nakagaki T, Fuse T, Mori T, Satoh K, Atarashi R, Nishida N (2015) Ubiquitin-specific protease 14 modulates degradation of cellular prion protein. Sci Rep 5:11028. https:// doi.org/10.1038/srep11028

Hoogeveen-Westerveld M, Exalto C, Maat-Kievit A, van den Ouweland A, Halley D, Nellist M (2010) Analysis of TSC1 truncations defines regions involved in TSC1 stability, aggregation and interaction. Biochimica Et Biophysica Acta (BBA) - Mol Basis Dis 1802:774-781. https://doi.org/10.1016/j.bbadis.2010.06.004

Huo Q (2010) Protein complexes/aggregates as potential cancer biomarkers revealed by a nanoparticle aggregation immunoassay. Colloids Surf B Biointerfaces 78:259-265. https://doi.org/10. 1016/j.colsurfb.2010.03.012

Hussain T, Zhao D, Shah SZA, Sabir N, Wang J, Liao Y, Song Y, Dong H, Hussain Mangi M, Ni J, Yang L, Zhou X (2019) Nilotinib: a tyrosine kinase inhibitor mediates resistance to intracellular mycobacterium via regulating autophagy. Cells. https://doi.org/ 10.3390/cells8050506

Hutt DM, Mishra SK, Roth DM, Larsen MB, Angles F, Frizzell RA, Balch WE (2018) Silencing of the Hsp70-specific nucleotideexchange factor BAG3 corrects the F508del-CFTR variant by restoring autophagy. J Biol Chem 293:13682-13695. https://doi. org/10.1074/jbc.RA118.002607

Hyer ML, Milhollen MA, Ciavarri J, Fleming P, Traore T, Sappal D, Huck J, Shi J, Gavin J, Brownell J, Yang Y, Stringer B, Griffin R, Bruzzese F, Soucy T, Duffy J, Rabino C, Riceberg J, Hoar K, Lublinsky A, Menon S, Sintchak M, Bump N, Pulukuri SM, Langston S, Tirrell S, Kuranda M, Veiby P, Newcomb J, Li P, 
Wu JT, Powe J, Dick LR, Greenspan P, Galvin K, Manfredi M, Claiborne C, Amidon BS, Bence NF (2018) A small-molecule inhibitor of the ubiquitin activating enzyme for cancer treatment. Nat Med 24:186-193. https://doi.org/10.1038/nm.4474

Hyrskyluoto A, Bruelle C, Lundh SH, Do HT, Kivinen J, Rappou E, Reijonen S, Waltimo T, Petersén Å, Lindholm D, Korhonen L (2014) Ubiquitin-specific protease-14 reduces cellular aggregates and protects against mutant huntingtin-induced cell degeneration: involvement of the proteasome and ER stress-activated kinase IRE1 $\alpha$. Hum Mol Genet 23:5928-5939. https://doi.org/10.1093/ hmg/ddu317

Hyun S, Shin D (2021) Chemical-mediated targeted protein degradation in neurodegenerative diseases. Life 11:607. https://doi.org/ 10.3390/life11070607

Ingre C, Roos PM, Piehl F, Kamel F, Fang F (2015) Risk factors for amyotrophic lateral sclerosis. Clin Epidemiol 7:181-193

Janus C, Pearson J, McLaurin J, Mathews PM, Jiang Y, Schmidt SD, Chishti MA, Horne P, Heslin D, French J, Mount HT, Nixon RA, Mercken M, Bergeron C, Fraser PE, St George-Hyslop P, Westaway D (2000) A beta peptide immunization reduces behavioural impairment and plaques in a model of Alzheimer's disease. Nature 408:979-982. https://doi.org/10.1038/35050110

Jayaraj GG, Hipp MS, Hartl FU (2020) Functional modules of the proteostasis network. Cold Spring Harb Perspect Biol. https:// doi.org/10.1101/cshperspect.a033951

Jiang J, Ballinger CA, Wu Y, Dai Q, Cyr DM, Höhfeld J, Patterson C (2001) CHIP is a U-box-dependent E3 ubiquitin ligase: identification of Hsc70 as a target for ubiquitylation. J Biol Chem 276:42938-42944. https://doi.org/10.1074/jbc.M101968200

Jiang H, Ren Y, Yuen EY, Zhong P, Ghaedi M, Hu Z, Azabdaftari G, Nakaso K, Yan Z, Feng J (2012) Parkin controls dopamine utilization in human midbrain dopaminergic neurons derived from induced pluripotent stem cells. Nat Commun 3:668. https://doi. org/10.1038/ncomms 1669

Jiang J, Zhu Q, Gendron TF, Saberi S, McAlonis-Downes M, Seelman A, Stauffer JE, Jafar-nejad P, Drenner K, Schulte D, Chun S, Sun S, Ling S-C, Myers B, Engelhardt J, Katz M, Baughn M, Platoshyn O, Marsala M, Watt A, Heyser CJ, Ard MC, De Muynck L, Daughrity LM, Swing DA, Tessarollo L, Jung CJ, Delpoux A, Utzschneider DT, Hedrick SM, de Jong PJ, Edbauer D, Van Damme P, Petrucelli L, Shaw CE, Bennett CF, Da Cruz S, Ravits J, Rigo F, Cleveland DW, Lagier-Tourenne C (2016) Gain of toxicity from ALS/FTD-linked repeat expansions in C9ORF72 is alleviated by antisense oligonucleotides targeting GGGGCC-containing RNAs. Neuron 90:535-550. https://doi. org/10.1016/j.neuron.2016.04.006

Jin M, Zhang Y (2020) Autophagy and autoimmune diseases. Adv Exp Med Biol 1207:405-408. https://doi.org/10.1007/978-98115-4272-5_28

Jung H, Lee HN, Marshall RS, Lomax AW, Yoon MJ, Kim J, Kim JH, Vierstra RD, Chung T (2020) Arabidopsis cargo receptor NBR1 mediates selective autophagy of defective proteins. J Exp Bot 71:73-89. https://doi.org/10.1093/jxb/erz404

Kalchman MA, Graham RK, Xia G, Koide HB, Hodgson JG, Graham KC, Goldberg YP, Gietz RD, Pickart CM, Hayden MR (1996) Huntingtin is ubiquitinated and interacts with a specific ubiquitin-conjugating enzyme. J Biol Chem 271:19385-19394. https:// doi.org/10.1074/jbc.271.32.19385

Kanapathipillai M (2018) Treating p53 mutant aggregation-associated cancer. Cancers (basel). https://doi.org/10.3390/cancers 100 60154

Karim MdR, Liao EE, Kim J, Meints J, Martinez HM, Pletnikova O, Troncoso JC, Lee MK (2020) $\alpha$-Synucleinopathy associated c-Abl activation causes p53-dependent autophagy impairment. Mol Neurodegener 15:27. https://doi.org/10.1186/ s13024-020-00364-w

Karuppagounder SS, Brahmachari S, Lee Y, Dawson VL, Dawson TM, Ko HS (2014) The c-Abl inhibitor, Nilotinib, protects dopaminergic neurons in a preclinical animal model of Parkinson's disease. Sci Rep 4:4874. https://doi.org/10.1038/srep04874

Kaverina NV, Kadagidze ZG, Borovjagin AV, Karseladze AI, Kim CK, Lesniak MS, Miska J, Zhang P, Baryshnikova MA, Xiao T, Ornelles D, Cobbs C, Khramtsov A, Ulasov IV (2018) Tamoxifen overrides autophagy inhibition in Beclin-1-deficient glioma cells and their resistance to adenovirus-mediated oncolysis via upregulation of PUMA and BAX. Oncogene 37:6069-6082. https://doi.org/10.1038/s41388-018-0395-9

Killick R, Scales G, Leroy K, Causevic M, Hooper C, Irvine EE, Choudhury AI, Drinkwater L, Kerr F, Al-Qassab H, Stephenson J, Yilmaz Z, Giese KP, Brion J-P, Withers DJ, Lovestone S (2009) Deletion of Irs2 reduces amyloid deposition and rescues behavioural deficits in APP transgenic mice. Biochem Biophys Res Commun 386:257-262. https://doi.org/10.1016/j.bbrc.2009. 06.032

Kilpatrick K, Zeng Y, Hancock T, Segatori L (2015) Genetic and chemical activation of TFEB mediates clearance of aggregated $\alpha$-synuclein. PLoS ONE 10:e0120819. https://doi.org/10.1371/ journal.pone.0120819

Kim Y-H, Rane A, Lussier S, Andersen JK (2011) Lithium protects against oxidative stress-mediated cell death in $\alpha$-synucleinoverexpressing in vitro and in vivo models of Parkinson's disease. J Neurosci Res 89:1666-1675. https://doi.org/10.1002/jnr. 22700

King MA, Hands S, Hafiz F, Mizushima N, Tolkovsky AM, Wyttenbach A (2008) Rapamycin inhibits polyglutamine aggregation independently of autophagy by reducing protein synthesis. Mol Pharmacol 73:1052-1063. https://doi.org/10.1124/mol.107. 043398

Kitajima Y, Tashiro Y, Suzuki N, Warita H, Kato M, Tateyama M, Ando R, Izumi R, Yamazaki M, Abe M, Sakimura K, Ito H, Urushitani M, Nagatomi R, Takahashi R, Aoki M (2014) Proteasome dysfunction induces muscle growth defects and protein aggregation. J Cell Sci 127:5204-5217. https://doi.org/10.1242/ jes. 150961

Klionsky DJ, Baehrecke EH, Brumell JH, Chu CT, Codogno P, Cuervo AM, Debnath J, Deretic V, Elazar Z, Eskelinen E-L, Finkbeiner S, Fueyo-Margareto J, Gewirtz D, Jäättelä M, Kroemer G, Levine B, Melia TJ, Mizushima N, Rubinsztein DC, Simonsen A, Thorburn A, Thumm M, Tooze SA (2011) A comprehensive glossary of autophagy-related molecules and processes. Autophagy 7:1273-1294. https://doi.org/10.4161/auto.7.11.17661

Komatsu M, Waguri S, Chiba T, Murata S, Iwata J, Tanida I, Ueno T, Koike M, Uchiyama Y, Kominami E, Tanaka K (2006) Loss of autophagy in the central nervous system causes neurodegeneration in mice. Nature 441:880-884. https://doi.org/10.1038/natur e04723

Koyano F, Okatsu K, Kosako H, Tamura Y, Go E, Kimura M, Kimura Y, Tsuchiya H, Yoshihara H, Hirokawa T, Endo T, Fon EA, Trempe J-F, Saeki Y, Tanaka K, Matsuda N (2014) Ubiquitin is phosphorylated by PINK1 to activate parkin. Nature 510:162166. https://doi.org/10.1038/nature13392

Koyuncu S, Saez I, Lee HJ, Gutierrez-Garcia R, Pokrzywa W, Fatima A, Hoppe T, Vilchez D (2018) The ubiquitin ligase UBR5 suppresses proteostasis collapse in pluripotent stem cells from Huntington's disease patients. Nat Commun 9:2886. https://doi.org/ 10.1038/s41467-018-05320-3

Koyuncu S, Loureiro R, Lee HJ, Wagle P, Krueger M, Vilchez D (2021) Rewiring of the ubiquitinated proteome determines 
ageing in C. elegans. Nature 596:285-290. https://doi.org/10. 1038/s41586-021-03781-z

Kröll-Hermi A, Ebstein F, Stoetzel C, Geoffroy V, Schaefer E, Scheidecker S, Bär S, Takamiya M, Kawakami K, Zieba BA, Studer F, Pelletier V, Eyermann C, Speeg-Schatz C, Laugel V, Lipsker D, Sandron F, McGinn S, Boland A, Deleuze J-F, Kuhn L, Chicher J, Hammann P, Friant S, Etard C, Krüger E, Muller J, Strähle U, Dollfus H (2020) Proteasome subunit PSMC3 variants cause neurosensory syndrome combining deafness and cataract due to proteotoxic stress. EMBO Mol Med 12:e11861. https:// doi.org/10.15252/emmm.201911861

Kuhn DJ, Chen Q, Voorhees PM, Strader JS, Shenk KD, Sun CM, Demo SD, Bennett MK, van Leeuwen FWB, Chanan-Khan AA, Orlowski RZ (2007) Potent activity of carfilzomib, a novel, irreversible inhibitor of the ubiquitin-proteasome pathway, against preclinical models of multiple myeloma. Blood 110:3281-3290. https://doi.org/10.1182/blood-2007-01-065888

Kumar V, Sami N, Kashav T, Islam A, Ahmad F, Hassan MdI (2016) Protein aggregation and neurodegenerative diseases: from theory to therapy. Eur J Med Chem 124:1105-1120. https://doi.org/10. 1016/j.ejmech.2016.07.054

Kurnik M, Sahin C, Andersen CB, Lorenzen N, Giehm L, MohammadBeigi H, Jessen CM, Pedersen JS, Christiansen G, Petersen SV, Staal R, Krishnamurthy G, Pitts K, Reinhart PH, Mulder FAA, Mente S, Hirst WD, Otzen DE (2018) Potent $\alpha$-synuclein aggregation inhibitors, identified by high-throughput screening, mainly target the monomeric state. Cell Chem Biol 25:1389-1402.e9. https://doi.org/10.1016/j.chembiol.2018.08.005

Lamberto GR, Binolfi A, Orcellet ML, Bertoncini CW, Zweckstetter M, Griesinger C, Fernández CO (2009) Structural and mechanistic basis behind the inhibitory interaction of PcTS on $\alpha$-synuclein amyloid fibril formation. Proc Natl Acad Sci USA 106:2105721062. https://doi.org/10.1073/pnas.0902603106

Lambert-Smith IA, Saunders DN, Yerbury JJ (2020) The pivotal role of ubiquitin-activating enzyme E1 (UBA1) in neuronal health and neurodegeneration. Int J Biochem Cell Biol 123:105746. https:// doi.org/10.1016/j.biocel.2020.105746

Lashuel HA (2021) Rethinking protein aggregation and drug discovery in neurodegenerative diseases: Why we need to embrace complexity? Curr Opin Chem Biol 64:67-75. https://doi.org/10. 1016/j.cbpa.2021.05.006

Lee E-N, Cho H-J, Lee C-H, Lee D, Chung KC, Paik SR (2004) Phthalocyanine tetrasulfonates affect the amyloid formation and cytotoxicity of alpha-synuclein. Biochemistry 43:3704-3715. https:// doi.org/10.1021/bi0356707

Lee B-H, Lee MJ, Park S, Oh D-C, Elsasser S, Chen P-C, Gartner C, Dimova N, Hanna J, Gygi SP, Wilson SM, King RW, Finley D (2010) Enhancement of proteasome activity by a small-molecule inhibitor of USP14. Nature 467:179-184. https://doi.org/ 10.1038/nature09299

Lee A, Rayner SL, Gwee SSL, De Luca A, Shahheydari H, Sundaramoorthy V, Ragagnin A, Morsch M, Radford R, Galper J, Freckleton S, Shi B, Walker AK, Don EK, Cole NJ, Yang S, Williams KL, Yerbury JJ, Blair IP, Atkin JD, Molloy MP, Chung RS (2018a) Pathogenic mutation in the ALS/FTD gene, CCNF, causes elevated Lys48-linked ubiquitylation and defective autophagy. Cell Mol Life Sci 75:335-354. https://doi.org/10. 1007/s00018-017-2632-8

Lee S, Choi B-R, Kim J, LaFerla FM, Park JHY, Han J-S, Lee KW, Kim J (2018b) Sulforaphane upregulates the heat shock protein co-chaperone CHIP and clears amyloid- $\beta$ and tau in a mouse model of Alzheimer's disease. Mol Nutr Food Res 62:1800240. https://doi.org/10.1002/mnfr.201800240

Leroy E, Boyer R, Auburger G, Leube B, Ulm G, Mezey E, Harta G, Brownstein MJ, Jonnalagada S, Chernova T, Dehejia A, Lavedan C, Gasser T, Steinbach PJ, Wilkinson KD, Polymeropoulos MH
(1998) The ubiquitin pathway in Parkinson's disease. Nature 395:451-452. https://doi.org/10.1038/26652

Levin J, Maaß S, Schuberth M, Giese A, Oertel WH, Poewe W, Trenkwalder C, Wenning GK, Mansmann U, Südmeyer M, Eggert K, Mollenhauer B, Lipp A, Löhle M, Classen J, Münchau A, Kassubek J, Gandor F, Berg D, Egert-Schwender S, Eberhardt C, Paul F, Bötzel K, Ertl-Wagner B, Huppertz H-J, Ricard I, Höglinger GU, André E, Blankenstein C, Canelo M, Düring M, Ebentheuer J, Fricke C, Gerbes A, Groiss S, Gruber D, Hartmann C, Kirchner T, Kroneberg D, Kunz M, Lorenzl S, Moldovan A, Noda A, Pape H, Respondek G, Schäffer E, Schneider M, Schnitzler A, Schulz-Schaeffer W, Schwarz J, Skowronek C, Storch A, Tadic V, Vadász D, Zimmermann B (2019) Safety and efficacy of epigallocatechin gallate in multiple system atrophy (PROMESA): a randomised, double-blind, placebo-controlled trial. The Lancet Neurology 18:724-735. https://doi.org/10.1016/S1474-4422(19) 30141-3

Levine B, Klionsky DJ (2004) Development by self-digestion: molecular mechanisms and biological functions of autophagy. Dev Cell 6:463-477. https://doi.org/10.1016/S1534-5807(04)00099-1

Li Z, Zhang W, Sima AAF (2007) Alzheimer-like changes in rat models of spontaneous diabetes. Diabetes 56:1817-1824. https://doi. org/10.2337/db07-0171

Li L, Fang R, Liu B, Shi H, Wang Y, Zhang W, Zhang X, Ye L (2016) Deacetylation of tumor-suppressor MST1 in Hippo pathway induces its degradation through HBXIP-elevated HDAC6 in promotion of breast cancer growth. Oncogene 35:4048-4057. https://doi.org/10.1038/onc.2015.476

Li Y, Chen Z, Lu Z, Yang Q, Liu L, Jiang Z, Zhang L, Zhang X, Qing $\mathrm{H}$ (2018) "Cell-addictive" dual-target traceable nanodrug for Parkinson's disease treatment via flotillins pathway. Theranostics 8:5469-5481. https://doi.org/10.7150/thno.28295

Liang C-C, Wang C, Peng X, Gan B, Guan J-L (2010) Neuralspecific deletion of FIP200 leads to cerebellar degeneration caused by increased neuronal death and axon degeneration*. J Biol Chem 285:3499-3509. https://doi.org/10.1074/jbc.M109. 072389

Liberman Z, Eldar-Finkelman H (2005) Serine 332 phosphorylation of insulin receptor substrate- 1 by glycogen synthase kinase- 3 attenuates insulin signaling*. J Biol Chem 280:4422-4428. https:// doi.org/10.1074/jbc.M410610200

Lim KL, Chew KCM, Tan JMM, Wang C, Chung KKK, Zhang Y, Tanaka Y, Smith W, Engelender S, Ross CA, Dawson VL, Dawson TM (2005) Parkin mediates nonclassical, proteasomal-independent ubiquitination of synphilin-1: implications for Lewy body formation. J Neurosci 25:2002-2009. https://doi.org/10.1523/ JNEUROSCI.4474-04.2005

Ling Y-H, Liebes L, Ng B, Buckley M, Elliott PJ, Adams J, Jiang J-D, Muggia FM, Perez-Soler R (2002) PS-341, a novel proteasome inhibitor, induces Bcl-2 phosphorylation and cleavage in association with G2-M phase arrest and apoptosis. Mol Cancer Ther 1:841-849

Liu Y, Fallon L, Lashuel HA, Liu Z, Lansbury PT (2002) The UCH-L1 gene encodes two opposing enzymatic activities that affect alphasynuclein degradation and Parkinson's disease susceptibility. Cell 111:209-218. https://doi.org/10.1016/s0092-8674(02)01012-7

Liu Y, Hettinger CL, Zhang D, Rezvani K, Wang X, Wang H (2014) Sulforaphane enhances proteasomal and autophagic activities in mice and is a potential therapeutic reagent for Huntington's disease. J Neurochem 129:539-547. https://doi.org/10.1111/jnc. 12647

Liu M, Qian T, Zhou W, Tao X, Sang S, Zhao L (2020a) Beneficial effects of low-dose lithium on cognitive ability and pathological alteration of Alzheimer's disease transgenic mice model. NeuroReport 31:943-951. https://doi.org/10.1097/WNR.00000 00000001499 
Liu T, Zhang J, Li K, Deng L, Wang H (2020b) Combination of an autophagy inducer and an autophagy inhibitor: a smarter strategy emerging in cancer therapy. Front Pharmacol 11:408. https://doi. org/10.3389/fphar.2020.00408

Liu Y, Tao S, Liao L, Li Y, Li H, Li Z, Lin L, Wan X, Yang X, Chen L (2020c) TRIM25 promotes the cell survival and growth of hepatocellular carcinoma through targeting Keap1-Nrf2 pathway. Nat Commun 11:348. https://doi.org/10.1038/s41467-019-14190-2

Liu-Yesucevitz L, Bilgutay A, Zhang Y-J, Vanderweyde T, Vanderwyde T, Citro A, Mehta T, Zaarur N, McKee A, Bowser R, Sherman M, Petrucelli L, Wolozin B (2010) Tar DNA binding protein-43 (TDP-43) associates with stress granules: analysis of cultured cells and pathological brain tissue. PLoS ONE 5:e13250. https:// doi.org/10.1371/journal.pone.0013250

Lloret A, Esteve D, Lloret M-A, Cervera-Ferri A, Lopez B, Nepomuceno M, Monllor P (2019) When does Alzheimer's disease really start? The role of biomarkers. Int J Mol Sci. https://doi.org/10. 3390/ijms20225536

Lochhead PA, Coghlan M, Rice SQJ, Sutherland C (2001) Inhibition of GSK-3 selectively reduces glucose-6-phosphatase and phosphoenolpyruvate carboxykinase gene expression. Diabetes 50:937-946. https://doi.org/10.2337/diabetes.50.5.937

Lokireddy S, Kukushkin NV, Goldberg AL (2015) cAMP-induced phosphorylation of 26S proteasomes on Rpn6/PSMD11 enhances their activity and the degradation of misfolded proteins. PNAS 112:E7176-E7185. https://doi.org/10.1073/pnas.1522332112

Long K, Williams TL, Urbanc B (2019) Insulin inhibits A $\beta 42$ aggregation and prevents $A \beta 42$-induced membrane disruption. Biochemistry 58:4519-4529. https://doi.org/10.1021/acs.biochem. 9b00696

Lonskaya I, Desforges NM, Hebron ML, Moussa CE-H (2013) Ubiquitination increases parkin activity to promote autophagic $\alpha$-synuclein clearance. PLoS ONE 8:e83914. https://doi.org/ 10.1371/journal.pone.0083914

Lopez-Otin C, Blasco MA, Partridge L, Serrano M, Kroemer G (2013) The hallmarks of aging. Cell 153:1194-1217

Lowe J, Blanchard A, Morrell K, Lennox G, Reynolds L, Billett M, Landon M, Mayer RJ (1988) Ubiquitin is a common factor in intermediate filament inclusion bodies of diverse type in man, including those of Parkinson's disease, Pick's disease, and Alzheimer's disease, as well as Rosenthal fibres in cerebellar astrocytomas, cytoplasmic bodies in muscle, and mallory bodies in alcoholic liver disease. J Pathol 155:9-15. https://doi. org/10.1002/path.1711550105

Lu J-H, Tan J-Q, Durairajan SSK, Liu L-F, Zhang Z-H, Ma L, Shen H-M, Chan HYE, Li M (2012) Isorhynchophylline, a natural alkaloid, promotes the degradation of alpha-synuclein in neuronal cells via inducing autophagy. Autophagy 8:98-108. https://doi.org/10.4161/auto.8.1.18313

Luciani A, Villella VR, Esposito S, Brunetti-Pierri N, Medina D, Settembre C, Gavina M, Pulze L, Giardino I, Pettoello-Mantovani M, D’Apolito M, Guido S, Masliah E, Spencer B, Quaratino S, Raia V, Ballabio A, Maiuri L (2010) Defective CFTR induces aggresome formation and lung inflammation in cystic fibrosis through ROS-mediated autophagy inhibition. Nat Cell Biol 12:863-875. https://doi.org/10.1038/ncb2090

Luo R, Su L-Y, Li G, Yang J, Liu Q, Yang L-X, Zhang D-F, Zhou H, Xu M, Fan Y, Li J, Yao Y-G (2020) Activation of PPARAmediated autophagy reduces Alzheimer disease-like pathology and cognitive decline in a murine model. Autophagy 16:52-69. https://doi.org/10.1080/15548627.2019.1596488

Ma Y-S, Wang X-F, Zhang Y-J, Luo P, Long H-D, Li L, Yang H-Q, Xie R-T, Jia C-Y, Lu G-X, Chang Z-Y, Zhang J-J, Xue S-B, Lv Z-W, Yu F, Xia Q, Fu D (2020) Inhibition of USP14 deubiquitinating activity as a potential therapy for tumors with p53 deficiency. Mol Ther Oncolytics 16:147-157. https://doi.org/ 10.1016/j.omto.2019.12.013

Maeda T, Eisenberg F (1980) Purification, structure, and catalytic properties of L-myo-inositol-1-phosphate synthase from rat testis. J Biol Chem 255:8458-8464

Magalhaes J, Gegg ME, Migdalska-Richards A, Schapira AH (2018) Effects of ambroxol on the autophagy-lysosome pathway and mitochondria in primary cortical neurons. Sci Rep 8:1385. https://doi.org/10.1038/s41598-018-19479-8

Maher-Edwards G, Zvartau-Hind M, Hunter AJ, Gold M, Hopton G, Jacobs G, Davy M, Williams P (2010) Double-blind, controlled phase II study of a 5-HT6 receptor antagonist, SB-742457, in Alzheimer's disease. Curr Alzheimer Res 7:374-385. https:// doi.org/10.2174/156720510791383831

Maher-Edwards G, Watson C, Ascher J, Barnett C, Boswell D, Davies J, Fernandez M, Kurz A, Zanetti O, Safirstein B, Schronen JP, Zvartau-Hind M, Gold M (2015) Two randomized controlled trials of SB742457 in mild-to-moderate Alzheimer's disease. Alzheimers Dement (NY) 1:23-36. https://doi.org/10. 1016/j.trci.2015.04.001

Majcher V, Goode A, James V, Layfield R (2015) Autophagy receptor defects and ALS-FTLD. Mol Cell Neurosci Protein Clear Neurodegener Dis Mech Ther 66:43-52. https://doi.org/10. 1016/j.men.2015.01.002

Majumder S, Richardson A, Strong R, Oddo S (2011) Inducing autophagy by rapamycin before, but not after, the formation of plaques and tangles ameliorates cognitive deficits. PLoS ONE 6:e25416. https://doi.org/10.1371/journal.pone.0025416

Malagelada C, Jin ZH, Jackson-Lewis V, Przedborski S, Greene LA (2010) Rapamycin protects against neuron death in in vitro andin vivo models of Parkinson's disease. J Neurosci 30:11661175. https://doi.org/10.1523/JNEUROSCI.3944-09.2010

Manasanch EE, Orlowski RZ (2017) Proteasome inhibitors in cancer therapy. Nat Rev Clin Oncol 14:417-433. https://doi.org/10. 1038/nrclinonc.2016.206

Mandrioli J, Crippa V, Cereda C, Bonetto V, Zucchi E, Gessani A, Ceroni M, Chio A, D’Amico R, Monsurrò MR, Riva N, Sabatelli M, Silani V, Simone IL, Sorarù G, Provenzani A, D’Agostino VG, Carra S, Poletti A (2019) Proteostasis and ALS: protocol for a phase II, randomised, double-blind, placebo-controlled, multicentre clinical trial for colchicine in ALS (Co-ALS). BMJ Open. https://doi.org/10.1136/bmjopen-2018-028486

Marchand B, Arsenault D, Raymond-Fleury A, Boisvert F-M, Boucher M-J (2015) Glycogen synthase kinase-3 (GSK3) inhibition induces prosurvival autophagic signals in human pancreatic cancer cells *. J Biol Chem 290:5592-5605. https://doi.org/10. 1074/jbc.M114.616714

Maria Fimia G, Stoykova A, Romagnoli A, Giunta L, Di Bartolomeo S, Nardacci R, Corazzari M, Fuoco C, Ucar A, Schwartz P, Gruss P, Piacentini M, Chowdhury K, Cecconi F (2007) Ambra1 regulates autophagy and development of the nervous system. Nature 447:1121-1125. https://doi.org/10.1038/nature05925

Marzella L, Ahlberg J, Glaumann H (1981) Autophagy, heterophagy, microautophagy and crinophagy as the means for intracellular degradation. Virchows Arch B Cell Pathol Incl Mol Pathol 36:219-234. https://doi.org/10.1007/BF02912068

Masaki K, Sonobe Y, Ghadge G, Pytel P, Roos RP (2019) TDP-43 proteinopathy in Theiler's murine encephalomyelitis virus infection. PLoS Pathog 15:e1007574. https://doi.org/10.1371/journ al.ppat. 1007574

Masini D, Bonito-Oliva A, Bertho M, Fisone G (2018) Inhibition of mTORC1 signaling reverts cognitive and affective deficits in a mouse model of Parkinson's disease. Front Neurol. https://doi. org/10.3389/fneur.2018.00208 
Masuda M, Suzuki N, Taniguchi S, Oikawa T, Nonaka T, Iwatsubo T, Hisanaga S, Goedert M, Hasegawa M (2006) Small molecule inhibitors of alpha-synuclein filament assembly. Biochemistry 45:6085-6094. https://doi.org/10.1021/bi0600749

McLoughlin HS, Moore LR, Paulson HL (2020) Pathogenesis of SCA3 and implications for other polyglutamine diseases. Neurobiol Dis 134:104635. https://doi.org/10.1016/j.nbd.2019.104635

McNaught KS, Olanow CW, Halliwell B, Isacson O, Jenner P (2001) Failure of the ubiquitin-proteasome system in Parkinson's disease. Nat Rev Neurosci 2:589-594. https://doi.org/10.1038/ 35086067

McNeill A, Magalhaes J, Shen C, Chau K-Y, Hughes D, Mehta A, Foltynie T, Cooper JM, Abramov AY, Gegg M, Schapira AHV (2014) Ambroxol improves lysosomal biochemistry in glucocerebrosidase mutation-linked Parkinson disease cells. Brain 137:1481-1495. https://doi.org/10.1093/brain/awu020

Meffre J, Chaumont-Dubel S, Mannoury la Cour C, Loiseau F, Watson DJG, Dekeyne A, Séveno M, Rivet J-M, Gaven F, Déléris P, Hervé D, Fone KCF, Bockaert J, Millan MJ, Marin P (2012) 5-HT(6) receptor recruitment of mTOR as a mechanism for perturbed cognition in schizophrenia. EMBO Mol Med 4:10431056. https://doi.org/10.1002/emmm.201201410

Melino G (2005) Discovery of the ubiquitin proteasome system and its involvement in apoptosis. Cell Death Differ 12:1155-1157. https://doi.org/10.1038/sj.cdd.4401740

Melis V, Magbagbeolu M, Rickard JE, Horsley D, Davidson K, Harrington KA, Goatman K, Goatman EA, Deiana S, Close SP, Zabke C, Stamer K, Dietze S, Schwab K, Storey JMD, Harrington CR, Wischik CM, Theuring F, Riedel G (2015) Effects of oxidized and reduced forms of methylthioninium in two transgenic mouse tauopathy models. Behav Pharmacol 26:353-368. https://doi.org/10.1097/FBP.0000000000000133

Meng Y, Qiao H, Ding J, He Y, Fan H, Li C, Qiu P (2020) Effect of Parkin on methamphetamine-induced $\alpha$-synuclein degradation dysfunction in vitro and in vivo. Brain Behav 10:e01574. https://doi.org/10.1002/brb3.1574

Menzies FM, Fleming A, Caricasole A, Bento CF, Andrews SP, Ashkenazi A, Füllgrabe J, Jackson A, Jimenez Sanchez M, Karabiyik C, Licitra F, Lopez Ramirez A, Pavel M, Puri C, Renna M, Ricketts T, Schlotawa L, Vicinanza M, Won H, Zhu Y, Skidmore J, Rubinsztein DC (2017) Autophagy and neurodegeneration: pathogenic mechanisms and therapeutic opportunities. Neuron 93:1015-1034. https://doi.org/10.1016/j.neuron. 2017.01.022

Meroni G, Diez-Roux G (2005) TRIM/RBCC, a novel class of "single protein RING finger" E3 ubiquitin ligases. BioEssays 27:1147-1157. https://doi.org/10.1002/bies.20304

Meshitsuka S, Shingaki S, Hotta M, Goto M, Kobayashi M, Ukawa Y, Sagesaka YM, Wada Y, Nojima M, Suzuki K (2017) Phase 2 trial of daily, oral epigallocatechin gallate in patients with light-chain amyloidosis. Int J Hematol 105:295-308. https:// doi.org/10.1007/s12185-016-2112-1

Miao G, Zhao H, Li Y, Ji M, Chen Y, Shi Y, Bi Y, Wang P, Zhang $\mathrm{H}$ (2021) ORF3a of the COVID-19 virus SARS-CoV-2 blocks HOPS complex-mediated assembly of the SNARE complex required for autolysosome formation. Dev Cell 56:427-442. e5. https://doi.org/10.1016/j.devcel.2020.12.010

Miller S, Muqit MMK (2019) Therapeutic approaches to enhance PINK1/Parkin mediated mitophagy for the treatment of Parkinson's disease. Neurosci Lett 705:7-13. https://doi.org/10. 1016/j.neulet.2019.04.029

Miller VM, Nelson RF, Gouvion CM, Williams A, Rodriguez-Lebron E, Harper SQ, Davidson BL, Rebagliati MR, Paulson HL (2005) CHIP suppresses polyglutamine aggregation and toxicity in vitro and in vivo. J Neurosci 25:9152-9161. https://doi. org/10.1523/JNEUROSCI.3001-05.2005
Minis A, Rodriguez JA, Levin A, Liu K, Govek E-E, Hatten ME, Steller H (2019) The proteasome regulator PI31 is required for protein homeostasis, synapse maintenance, and neuronal survival in mice. PNAS 116:24639-24650. https://doi.org/10. 1073/pnas.1911921116

Mizushima N (2007) Autophagy: process and function. Genes Dev 21:2861-2873. https://doi.org/10.1101/gad.1599207

Moors TE, Hoozemans JJM, Ingrassia A, Beccari T, Parnetti L, Chartier-Harlin M-C, van de Berg WDJ (2017) Therapeutic potential of autophagy-enhancing agents in Parkinson's disease. Mol Neurodegener 12:11. https://doi.org/10.1186/ s13024-017-0154-3

Morgan D, Diamond DM, Gottschall PE, Ugen KE, Dickey C, Hardy J, Duff K, Jantzen P, DiCarlo G, Wilcock D, Connor K, Hatcher J, Hope C, Gordon M, Arendash GW (2000) A beta peptide vaccination prevents memory loss in an animal model of Alzheimer's disease. Nature 408:982-985. https://doi.org/10.1038/ 35050116

Mori K, Weng S-M, Arzberger T, May S, Rentzsch K, Kremmer E, Schmid B, Kretzschmar HA, Cruts M, Van Broeckhoven C, Haass C, Edbauer D (2013) The C9orf72 GGGGCC repeat is translated into aggregating dipeptide-repeat proteins in FTLD/ ALS. Science 339:1335-1338. https://doi.org/10.1126/science. 1232927

Morishita H, Eguchi S, Kimura H, Sasaki J, Sakamaki Y, Robinson ML, Sasaki T, Mizushima N (2013) Deletion of autophagyrelated 5 (Atg5) and Pik3c3 genes in the lens causes cataract independent of programmed organelle degradation. J Biol Chem 288:11436-11447. https://doi.org/10.1074/jbc.M112.437103

Motoi Y, Shimada K, Ishiguro K, Hattori N (2014) Lithium and autophagy. ACS Chem Neurosci 5:434-442. https://doi.org/10. $1021 / \mathrm{cn} 500056 \mathrm{q}$

Mudshinge SR, Deore AB, Patil S, Bhalgat CM (2011) Nanoparticles: emerging carriers for drug delivery. Saudi Pharm J 19:129-141. https://doi.org/10.1016/j.jsps.2011.04.001

Mulcahy Levy JM, Thorburn A (2020) Autophagy in cancer: moving from understanding mechanism to improving therapy responses in patients. Cell Death Differ 27:843-857. https:// doi.org/10.1038/s41418-019-0474-7

Mulcahy Levy JM, Towers CG, Thorburn A (2017) Targeting autophagy in cancer. Nat Rev Cancer 17:528-542. https://doi. org/10.1038/nrc.2017.53

Mullin S, Smith L, Lee K, D’Souza G, Woodgate P, Elflein J, Hällqvist J, Toffoli M, Streeter A, Hosking J, Heywood WE, Khengar R, Campbell P, Hehir J, Cable S, Mills K, Zetterberg H, Limousin P, Libri V, Foltynie T, Schapira AHV (2020) Ambroxol for the treatment of patients with parkinson disease with and without glucocerebrosidase gene mutations: a nonrandomized, noncontrolled trial. JAMA Neurol 77:427-434. https://doi.org/10.1001/jamaneurol.2019.4611

Muscolino E, Schmitz R, Loroch S, Caragliano E, Schneider C, Rizzato M, Kim Y-H, Krause E, Juranić Lisnić V, Sickmann A, Reimer R, Ostermann E, Brune W (2020) Herpesviruses induce aggregation and selective autophagy of host signalling proteins NEMO and RIPK1 as an immune-evasion mechanism. Nat Microbiol 5:331-342. https://doi.org/10.1038/ s41564-019-0624-1

Mushtaq G, Khan JA, Joseph E, Kamal MA (2015) Nanoparticles, neurotoxicity and neurodegenerative diseases. Curr Drug Metab 16:676-684. https://doi.org/10.2174/13892002166661508121 22302

Nagai Y, Tucker T, Ren H, Kenan DJ, Henderson BS, Keene JD, Strittmatter WJ, Burke JR (2000) Inhibition of polyglutamine protein aggregation and cell death by novel peptides identified by phage display screening. J Biol Chem 275:10437-10442. https://doi. org/10.1074/jbc.275.14.10437 
Nah J, Yuan J, Jung Y-K (2015) Autophagy in neurodegenerative diseases: from mechanism to therapeutic approach. Mol Cells 38:381-389

Nakamura S, Oba M, Suzuki M, Takahashi A, Yamamuro T, Fujiwara M, Ikenaka K, Minami S, Tabata N, Yamamoto K, Kubo S, Tokumura A, Akamatsu K, Miyazaki Y, Kawabata T, Hamasaki M, Fukui K, Sango K, Watanabe Y, Takabatake Y, Kitajima TS, Okada Y, Mochizuki H, Isaka Y, Antebi A, Yoshimori T (2019) Suppression of autophagic activity by Rubicon is a signature of aging. Nat Commun 10:847. https://doi.org/10.1038/ s41467-019-08729-6

Nazé P, Vuillaume I, Destée A, Pasquier F, Sablonnière B (2002) Mutation analysis and association studies of the ubiquitin carboxyterminal hydrolase L1 gene in Huntington's disease. Neurosci Lett 328:1-4. https://doi.org/10.1016/s0304-3940(02)00231-8

Nencioni A, Grünebach F, Patrone F, Ballestrero A, Brossart P (2007) Proteasome inhibitors: antitumor effects and beyond. Leukemia 21:30-36. https://doi.org/10.1038/sj.leu.2404444

Neugroschl J, Sano M (2010) Current treatment and recent clinical research in Alzheimer's disease. Mt Sinai J Med 77:3-16. https:// doi.org/10.1002/msj.20165

Neumann M, Sampathu DM, Kwong LK, Truax AC, Micsenyi MC, Chou TT, Bruce J, Schuck T, Grossman M, Clark CM, McCluskey LF, Miller BL, Masliah E, Mackenzie IR, Feldman H, Feiden W, Kretzschmar HA, Trojanowski JQ, Lee VM-Y (2006) Ubiquitinated TDP-43 in frontotemporal lobar degeneration and amyotrophic lateral sclerosis. Science 314:130-133. https://doi. org/10.1126/science. 1134108

Ng C-H, Guan MSH, Koh C, Ouyang X, Yu F, Tan E-K, O’Neill SP, Zhang X, Chung J, Lim K-L (2012) AMP kinase activation mitigates dopaminergic dysfunction and mitochondrial abnormalities in drosophila models of Parkinson's disease. J Neurosci 32:14311-14317. https://doi.org/10.1523/JNEUR OSCI.0499-12.2012

Nie Q, Du X, Geng M (2011) Small molecule inhibitors of amyloid $\beta$ peptide aggregation as a potential therapeutic strategy for Alzheimer's disease. Acta Pharmacol Sin 32:545-551. https:// doi.org/10.1038/aps.2011.14

Nixon RA (2013) The role of autophagy in neurodegenerative disease. Nat Med 19:983-997. https://doi.org/10.1038/nm.3232

Norris KL, Hao R, Chen L-F, Lai C-H, Kapur M, Shaughnessy PJ, Chou D, Yan J, Taylor JP, Engelender S, West AE, Lim K-L, Yao T-P (2015) Convergence of Parkin, PINK1, and $\alpha$-synuclein on stress-induced mitochondrial morphological remodeling *. J Biol Chem 290:13862-13874. https://doi.org/ 10.1074/jbc.M114.634063

Oddo S, Caccamo A, Tseng B, Cheng D, Vasilevko V, Cribbs DH, LaFerla FM (2008) Blocking Abeta42 accumulation delays the onset and progression of tau pathology via the $\mathrm{C}$ terminus of heat shock protein70-interacting protein: a mechanistic link between Abeta and tau pathology. J Neurosci 28:12163-12175. https://doi.org/10.1523/JNEUROSCI.2464-08.2008

Oishi S, Premarathne S, Harvey TJ, Iyer S, Dixon C, Alexander S, Burne THJ, Wood SA, Piper M (2016) Usp9x-deficiency disrupts the morphological development of the postnatal hippocampal dentate gyrus. Sci Rep 6:25783. https://doi.org/10. 1038/srep25783

Orlowski RZ, Kuhn DJ (2008) Proteasome inhibitors in cancer therapy: lessons from the first decade. Clin Cancer Res 14:16491657. https://doi.org/10.1158/1078-0432.CCR-07-2218

Orlowski RZ, Eswara JR, Lafond-Walker A, Grever MR, Orlowski M, Dang CV (1998) Tumor growth inhibition induced in a murine model of human Burkitt's lymphoma by a proteasome inhibitor. Cancer Res 58:4342-4348

Ortuno D, Carlisle HJ, Miller S (2016) Does inactivation of USP14 enhance degradation of proteasomal substrates that are associated with neurodegenerative diseases? F1000Res 5:137. https://doi.org/10.12688/f1000research.7800.2

Osaki T, Uzel SGM, Kamm RD (2018) Microphysiological 3D model of amyotrophic lateral sclerosis (ALS) from human iPSderived muscle cells and optogenetic motor neurons. Sci Adv 4:eaat847. https://doi.org/10.1126/sciadv.aat5847

Pagan F, Hebron M, Valadez EH, Torres-Yaghi Y, Huang X, Mills RR, Wilmarth BM, Howard H, Dunn C, Carlson A, Lawler A, Rogers SL, Falconer RA, Ahn J, Li Z, Moussa C (2016) Nilotinib effects in Parkinson's disease and dementia with lewy bodies. J Parkinsons Dis 6:503-517. https://doi.org/10.3233/ JPD-160867

Palomo GM, Granatiero V, Kawamata H, Konrad C, Kim M, Arreguin AJ, Zhao D, Milner TA, Manfredi G (2018) Parkin is a disease modifier in the mutant SOD1 mouse model of ALS. EMBO Mol Med. https://doi.org/10.15252/emmm.201808888

Pandey N, Strider J, Nolan WC, Yan SX, Galvin JE (2008) Curcumin inhibits aggregation of $\alpha$-synuclein. Acta Neuropathol 115:479489. https://doi.org/10.1007/s00401-007-0332-4

Park H, Kang J-H, Lee S (2020) Autophagy in neurodegenerative diseases: a hunter for aggregates. Int J Mol Sci. https://doi.org/10. 3390/ijms21093369

Patil SP, Jain PD, Ghumatkar PJ, Tambe R, Sathaye S (2014) Neuroprotective effect of metformin in MPTP-induced Parkinson's disease in mice. Neuroscience 277:747-754. https://doi.org/10. 1016/j.neuroscience.2014.07.046

Patra JK, Das G, Fraceto LF, Campos EVR, del Rodriguez-Torres MP, Acosta-Torres LS, Diaz-Torres LA, Grillo R, Swamy MK, Sharma S, Habtemariam S, Shin H-S (2018) Nano based drug delivery systems: recent developments and future prospects. J Nanobiotechnol 16:71. https://doi.org/10.1186/ s12951-018-0392-8

Pei X-Y, Dai Y, Grant S (2003) The proteasome inhibitor bortezomib promotes mitochondrial injury and apoptosis induced by the small molecule Bcl-2 inhibitor HA14-1 in multiple myeloma cells. Leukemia 17:2036-2045. https://doi.org/10.1038/sj.leu. 2403109

Peng H, Yang F, Hu Q, Sun J, Peng C, Zhao Y, Huang C (2020) The ubiquitin-specific protease USP8 directly deubiquitinates SQSTM1/p62 to suppress its autophagic activity. Autophagy 16:698-708. https://doi.org/10.1080/15548627.2019.1635381

Penke B, Bogár F, Fülöp L (2017) $\beta$-Amyloid and the pathomechanisms of Alzheimer's disease: a comprehensive view. Molecules 22:1692. https://doi.org/10.3390/molecules22101692

Perry G, Friedman R, Shaw G, Chau V (1987) Ubiquitin is detected in neurofibrillary tangles and senile plaque neurites of Alzheimer disease brains. Proc Natl Acad Sci USA 84:3033-3036. https:// doi.org/10.1073/pnas.84.9.3033

Peters LZ, Karmon O, David-Kadoch G, Hazan R, Yu T, Glickman MH, Ben-Aroya S (2015) The protein quality control machinery regulates its misassembled proteasome subunits. PLoS Genet 11:e1005178. https://doi.org/10.1371/journal.pgen.1005178

Petrucelli L, O'Farrell C, Lockhart PJ, Baptista M, Kehoe K, Vink L, Choi P, Wolozin B, Farrer M, Hardy J, Cookson MR (2002) Parkin protects against the toxicity associated with mutant $\alpha$-synuclein: proteasome dysfunction selectively affects catecholaminergic neurons. Neuron 36:1007-1019. https://doi.org/10. 1016/S0896-6273(02)01125-X

Pickford F, Masliah E, Britschgi M, Lucin K, Narasimhan R, Jaeger PA, Small S, Spencer B, Rockenstein E, Levine B, Wyss-Coray $\mathrm{T}$ (2008) The autophagy-related protein beclin 1 shows reduced expression in early Alzheimer disease and regulates amyloid $\beta$ accumulation in mice. J Clin Invest 118:2190-2199. https://doi. org/10.1172/JCI33585

Pinto-Fernández A, Davis S, Schofield AB, Scott HC, Zhang P, Salah E, Mathea S, Charles PD, Damianou A, Bond G, Fischer R, 
Kessler BM (2019) Comprehensive landscape of active deubiquitinating enzymes profiled by advanced chemoproteomics. Front Chem 7:592. https://doi.org/10.3389/fchem.2019.00592

Pizzasegola C, Caron I, Daleno C, Ronchi A, Minoia C, Carrì MT, Bendotti C (2009) Treatment with lithium carbonate does not improve disease progression in two different strains of SOD1 mutant mice. Amyotroph Lateral Scler 10:221-228. https://doi. org/10.1080/17482960902803440

Plechanovová A, Jaffray E, Tatham MH, Naismith JH, Hay RT (2012) Structure of a RING E3 ligase and ubiquitin-loaded E2 primed for catalysis. Nature 489:115-120. https://doi.org/10.1038/natur e11376

Poole AC, Thomas RE, Yu S, Vincow ES, Pallanck L (2010) The mitochondrial fusion-promoting factor mitofusin is a substrate of the PINK1/parkin pathway. PLoS ONE 5:e10054. https://doi.org/10. 1371/journal.pone.0010054

Pouladi MA, Brillaud E, Xie Y, Conforti P, Graham RK, Ehrnhoefer DE, Franciosi S, Zhang W, Poucheret P, Compte E, Maurel J-C, Zuccato C, Cattaneo E, Néri C, Hayden MR (2012) NP03, a novel low-dose lithium formulation, is neuroprotective in the YAC128 mouse model of Huntington disease. Neurobiol Dis 48:282-289. https://doi.org/10.1016/j.nbd.2012.06.026

Qi L, Tang Y, He W, Pan H, Jiang W, Wang L, Deng W (2017) Lithium chloride promotes neuronal differentiation of rat neural stem cells and enhances neural regeneration in Parkinson's disease model. Cytotechnology 69:277-287. https://doi.org/10.1007/ s10616-016-0056-1

Quach C, Song Y, Guo H, Li S, Maazi H, Fung M, Sands N, O'Connell D, Restrepo-Vassalli S, Chai B, Nemecio D, Punj V, Akbari O, Idos GE, Mumenthaler SM, Wu N, Martin SE, Hagiya A, Hicks J, Cui H, Liang C (2019) A truncating mutation in the autophagy gene UVRAG drives inflammation and tumorigenesis in mice. Nat Commun 10:5681. https://doi.org/10.1038/ s41467-019-13475-w

Rabanal-Ruiz Y, Otten EG, Korolchuk VI (2017) mTORC1 as the main gateway to autophagy. Essays Biochem 61:565-584. https://doi. org/10.1042/EBC20170027

Rana A, Rera M, Walker DW (2013) Parkin overexpression during aging reduces proteotoxicity, alters mitochondrial dynamics, and extends lifespan. Proc Natl Acad Sci USA 110:8638-8643. https://doi.org/10.1073/pnas.1216197110

Rane JS, Bhaumik P, Panda D (2017) Curcumin inhibits tau aggregation and disintegrates preformed tau filaments in vitro. J Alzheimers Dis 60:999-1014. https://doi.org/10.3233/JAD-170351

Ratjen F, Döring G (2003) Cystic fibrosis. Lancet 361:681-689. https:// doi.org/10.1016/S0140-6736(03)12567-6

Ravikumar B, Duden R, Rubinsztein DC (2002) Aggregate-prone proteins with polyglutamine and polyalanine expansions are degraded by autophagy. Hum Mol Genet 11:1107-1117. https:// doi.org/10.1093/hmg/11.9.1107

Ravikumar B, Vacher C, Berger Z, Davies JE, Luo S, Oroz LG, Scaravilli F, Easton DF, Duden R, O'Kane CJ, Rubinsztein DC (2004) Inhibition of mTOR induces autophagy and reduces toxicity of polyglutamine expansions in fly and mouse models of Huntington disease. Nat Genet 36:585-595. https://doi.org/10.1038/ ng 1362

Ren J, Liu T, Han Y, Wang Q, Chen Y, Li G, Jiang L (2018) GSK-3 $\beta$ inhibits autophagy and enhances radiosensitivity in non-small cell lung cancer. Diagn Pathol 13:33. https://doi.org/10.1186/ s13000-018-0708-X

Renton AE, Majounie E, Waite A, Simón-Sánchez J, Rollinson S, Gibbs JR, Schymick JC, Laaksovirta H, van Swieten JC, Myllykangas L, Kalimo H, Paetau A, Abramzon Y, Remes AM, Kaganovich A, Scholz SW, Duckworth J, Ding J, Harmer DW, Hernandez DG, Johnson JO, Mok K, Ryten M, Trabzuni D,
Guerreiro RJ, Orrell RW, Neal J, Murray A, Pearson J, Jansen IE, Sondervan D, Seelaar H, Blake D, Young K, Halliwell N, Callister JB, Toulson G, Richardson A, Gerhard A, Snowden J, Mann D, Neary D, Nalls MA, Peuralinna T, Jansson L, Isoviita V-M, Kaivorinne A-L, Hölttä-Vuori M, Ikonen E, Sulkava R, Benatar M, Wuu J, Chiò A, Restagno G, Borghero G, Sabatelli M, Heckerman D, Rogaeva E, Zinman L, Rothstein JD, Sendtner M, Drepper C, Eichler EE, Alkan C, Abdullaev Z, Pack SD, Dutra A, Pak E, Hardy J, Singleton A, Williams NM, Heutink P, Pickering-Brown S, Morris HR, Tienari PJ, Traynor BJ, ITALSGEN Consortium (2011) A hexanucleotide repeat expansion in C9ORF72 is the cause of chromosome 9p21-linked ALS-FTD. Neuron 72:257-268. https://doi.org/10.1016/j.neuron.2011.09. 010

Renton AE, Chiò A, Traynor BJ (2014) State of play in amyotrophic lateral sclerosis genetics. Nat Neurosci 17:17-23. https://doi.org/ $10.1038 / \mathrm{nn} .3584$

Richardson PG, Mitsiades C, Schlossman R, Ghobrial I, Hideshima $\mathrm{T}$, Munshi N, Anderson KC (2008) Bortezomib in the front-line treatment of multiple myeloma. Expert Rev Anticancer Ther 8:1053-1072. https://doi.org/10.1586/14737140.8.7.1053

Richter F, Fleming SM, Watson M, Lemesre V, Pellegrino L, Ranes B, Zhu C, Mortazavi F, Mulligan CK, Sioshansi PC, Hean S, De La Rosa K, Khanna R, Flanagan J, Lockhart DJ, Wustman BA, Clark SW, Chesselet M-F (2014) A GCase chaperone improves motor function in a mouse model of synucleinopathy. Neurotherapeutics 11:840-856. https://doi.org/10.1007/s13311-014-0294-X

Ringman JM, Frautschy SA, Teng E, Begum AN, Bardens J, Beigi M, Gylys KH, Badmaev V, Heath DD, Apostolova LG, Porter V, Vanek Z, Marshall GA, Hellemann G, Sugar C, Masterman DL, Montine TJ, Cummings JL, Cole GM (2012) Oral curcumin for Alzheimer's disease: tolerability and efficacy in a 24-week randomized, double blind, placebo-controlled study. Alzheimers Res Ther 4:43. https://doi.org/10.1186/alzrt146

Rippin I, Bonder K, Joseph S, Sarsor A, Vaks L, Eldar-Finkelman H (2021) Inhibition of GSK-3 ameliorates the pathogenesis of Huntington's disease. Neurobiol Dis 154:105336. https://doi.org/ 10.1016/j.nbd.2021.105336

Rousseau E, Kojima R, Hoffner G, Djian P, Bertolotti A (2009) Misfolding of proteins with a polyglutamine expansion is facilitated by proteasomal chaperones. J Biol Chem 284:1917-1929. https:// doi.org/10.1074/jbc.M806256200

Ruberg FL, Berk JL (2012) Transthyretin (TTR) cardiac amyloidosis. Circulation 126:1286-1300. https://doi.org/10.1161/CIRCU LATIONAHA.111.078915

Rubinsztein DC, Nixon RA (2010) Rapamycin induces autophagic flux in neurons. PNAS 107:E181-E181. https://doi.org/10.1073/pnas. 1014633107

Rudich P, Snoznik C, Watkins SC, Monaghan J, Pandey UB, Lamitina ST (2017) Nuclear localized C9orf72-associated arginine-containing dipeptides exhibit age-dependent toxicity in C. elegans. Hum Mol Genet 26:4916-4928. https://doi.org/10.1093/hmg/ ddx 372

Ruggenenti P, Gentile G, Perico N, Perna A, Barcella L, Trillini M, Cortinovis M, Ferrer Siles CP, Reyes Loaeza JA, Aparicio MC, Fasolini G, Gaspari F, Martinetti D, Carrara F, Rubis N, Prandini S, Caroli A, Sharma K, Antiga L, Remuzzi A, Remuzzi G, SIRENA 2 Study Group (2016) Effect of sirolimus on disease progression in patients with autosomal dominant polycystic kidney disease and CKD stages 3b-4. Clin J Am Soc Nephrol 11:785-794. https://doi.org/10.2215/CJN.09900915

Ryu HY, Kim LE, Jeong H, Yeo BK, Lee J-W, Nam H, Ha S, An H-K, Park H, Jung S, Chung KM, Kim J, Lee B-H, Cheong H, Kim E-K, Yu S-W (2021) GSK3B induces autophagy by 
phosphorylating ULK1. Exp Mol Med 53:369-383. https://doi. org/10.1038/s12276-021-00570-6

Sadagurski M, Cheng Z, Rozzo A, Palazzolo I, Kelley GR, Dong X, Krainc D, White MF (2011) IRS2 increases mitochondrial dysfunction and oxidative stress in a mouse model of Huntington disease. J Clin Invest 121:4070-4081. https://doi.org/10.1172/ JCI46305

Saez I, Vilchez D (2014) The mechanistic links between proteasome activity, aging and agerelated diseases. Curr Genomics 15:38-51

Saez I, Koyuncu S, Gutierrez-Garcia R, Dieterich C, Vilchez D (2018) Insights into the ubiquitin-proteasome system of human embryonic stem cells. Sci Rep 8:4092. https://doi.org/10.1038/ s41598-018-22384-9

Saigoh K, Wang YL, Suh JG, Yamanishi T, Sakai Y, Kiyosawa H, Harada T, Ichihara N, Wakana S, Kikuchi T, Wada K (1999) Intragenic deletion in the gene encoding ubiquitin carboxy-terminal hydrolase in gad mice. Nat Genet 23:47-51. https://doi. org/10.1038/12647

Salahuddin P, Khan RH, Furkan M, Uversky VN, Islam Z, Fatima MT (2021) Mechanisms of amyloid proteins aggregation and their inhibition by antibodies, small molecule inhibitors, nanoparticles and nano-bodies. Int J Biol Macromol 186:580-590. https://doi.org/10.1016/j.ijbiomac.2021.07.056

Sarkar S, Floto RA, Berger Z, Imarisio S, Cordenier A, Pasco M, Cook LJ, Rubinsztein DC (2005) Lithium induces autophagy by inhibiting inositol monophosphatase. J Cell Biol 170:1101-1111. https://doi.org/10.1083/jcb.200504035

Sarraf SA, Raman M, Guarani-Pereira V, Sowa ME, Huttlin EL, Gygi SP, Harper JW (2013) Landscape of the PARKIN-dependent ubiquitylome in response to mitochondrial depolarization. Nature 496:372-376. https://doi.org/10.1038/nature12043

Sarraf SA, Shah HV, Kanfer G, Pickrell AM, Holtzclaw LA, Ward ME, Youle RJ (2020) Loss of TAX1BP1-directed autophagy results in protein aggregate accumulation in the brain. Mol Cell 80:779795.e10. https://doi.org/10.1016/j.molcel.2020.10.041

Savolainen MH, Richie CT, Harvey BK, Männistö PT, Maguire-Zeiss KA, Myöhänen TT (2014) The beneficial effect of a prolyl oligopeptidase inhibitor, KYP-2047, on alpha-synuclein clearance and autophagy in A30P transgenic mouse. Neurobiol Dis 68:1-15. https://doi.org/10.1016/j.nbd.2014.04.003

Schenk D, Barbour R, Dunn W, Gordon G, Grajeda H, Guido T, Hu K, Huang J, Johnson-Wood K, Khan K, Kholodenko D, Lee M, Liao Z, Lieberburg I, Motter R, Mutter L, Soriano F, Shopp G, Vasquez N, Vandevert C, Walker S, Wogulis M, Yednock T, Games D, Seubert P (1999) Immunization with amyloid- $\beta$ attenuates Alzheimer-disease-like pathology in the PDAPP mouse. Nature 400:173-177. https://doi.org/10.1038/22124

Schmidt MF, Gan ZY, Komander D, Dewson G (2021) Ubiquitin signalling in neurodegeneration: mechanisms and therapeutic opportunities. Cell Death Differ 28:570-590. https://doi.org/10. 1038/s41418-020-00706-7

Schwab K, Frahm S, Horsley D, Rickard JE, Melis V, Goatman EA, Magbagbeolu M, Douglas M, Leith MG, Baddeley TC, Storey JMD, Riedel G, Wischik CM, Harrington CR, Theuring F (2018) A Protein Aggregation Inhibitor, Leuco-Methylthioninium Bis(Hydromethanesulfonate), Decreases $\alpha$-Synuclein Inclusions in a Transgenic Mouse Model of Synucleinopathy. Front Mol Neurosci 10:447. https://doi.org/10.3389/fnmol.2017.00447

Sehgal SN, Baker H, Vézina C (1975) Rapamycin (AY-22,989), a new antifungal antibiotic. II. Fermentation, isolation and characterization. J Antibiot (tokyo) 28:727-732. https://doi.org/10.7164/ antibiotics.28.727

Seirafi M, Kozlov G, Gehring K (2015) Parkin structure and function. FEBS J 282:2076-2088. https://doi.org/10.1111/febs.13249
Selkoe DJ (2011) Alzheimer's disease. Cold Spring Harb Perspect Biol 3:a004457. https://doi.org/10.1101/cshperspect.a004457

Setsuie R, Wada K (2007) The functions of UCH-L1 and its relation to neurodegenerative diseases. Neurochem Int 51:105-111. https:// doi.org/10.1016/j.neuint.2007.05.007

Sha Z, Zhao J, Goldberg AL (2018) Measuring the overall rate of protein breakdown in cells and the contributions of the ubiquitinproteasome and autophagy-lysosomal pathways. In: Mayor T, Kleiger $\mathrm{G}$ (eds) The ubiquitin proteasome system methods and protocols, methods in molecular biology. Springer, New York, pp 261-276. https://doi.org/10.1007/978-1-4939-8706-1_17

Shannon KM (2011) Huntington's disease - clinical signs, symptoms, presymptomatic diagnosis, and diagnosis. Handb Clin Neurol 100:3-13. https://doi.org/10.1016/B978-0-444-52014-2.00001-X

Sharma N, Nehru B (2018) Curcumin affords neuroprotection and inhibits $\alpha$-synuclein aggregation in lipopolysaccharide-induced Parkinson's disease model. Inflammopharmacology 26:349-360. https://doi.org/10.1007/s10787-017-0402-8

Shiau AK, Barstad D, Loria PM, Cheng L, Kushner PJ, Agard DA, Greene GL (1998) The structural basis of estrogen receptor/ coactivator recognition and the antagonism of this interaction by tamoxifen. Cell 95:927-937. https://doi.org/10.1016/S00928674(00)81717-1

Shimura H, Schlossmacher MG, Hattori N, Frosch MP, Trockenbacher A, Schneider R, Mizuno Y, Kosik KS, Selkoe DJ (2001) Ubiquitination of a new form of $\alpha$-synuclein by parkin from human brain: implications for Parkinson's disease. Science 293:263269. https://doi.org/10.1126/science.1060627

Shimura H, Schwartz D, Gygi SP, Kosik KS (2004) CHIP-Hsc70 complex ubiquitinates phosphorylated tau and enhances cell survival *. J Biol Chem 279:4869-4876. https://doi.org/10.1074/jbc. M305838200

Shin J-H, Ko HS, Kang H, Lee Y, Lee Y-I, Pletinkova O, Troconso JC, Dawson VL, Dawson TM (2011) PARIS (ZNF746) repression of PGC- $1 \alpha$ contributes to neurodegeneration in Parkinson's disease. Cell 144:689-702. https://doi.org/10.1016/j.cell.2011.02.010

Shoji-Kawata S, Sumpter R, Leveno M, Campbell GR, Zou Z, Kinch L, Wilkins AD, Sun Q, Pallauf K, MacDuff D, Huerta C, Virgin HW, Helms JB, Eerland R, Tooze SA, Xavier R, Lenschow DJ, Yamamoto A, King D, Lichtarge O, Grishin NV, Spector SA, Kaloyanova DV, Levine B (2013) Identification of a candidate therapeutic autophagy-inducing peptide. Nature 494:201-206. https://doi.org/10.1038/nature11866

Sidransky E, Lopez G (2012) The link between the GBA gene and parkinsonism. Lancet Neurol 11:986-998. https://doi.org/10.1016/ S1474-4422(12)70190-4

Sidransky E, Nalls MA, Aasly JO, Aharon-Peretz J, Annesi G, Barbosa ER, Bar-Shira A, Berg D, Bras J, Brice A, Chen C-M, Clark LN, Condroyer C, De Marco EV, Dürr A, Eblan MJ, Fahn S, Farrer MJ, Fung H-C, Gan-Or Z, Gasser T, Gershoni-Baruch R, Giladi N, Griffith A, Gurevich T, Januario C, Kropp P, Lang AE, Lee-Chen G-J, Lesage S, Marder K, Mata IF, Mirelman A, Mitsui J, Mizuta I, Nicoletti G, Oliveira C, Ottman R, Orr-Urtreger A, Pereira LV, Quattrone A, Rogaeva E, Rolfs A, Rosenbaum H, Rozenberg R, Samii A, Samaddar T, Schulte C, Sharma M, Singleton A, Spitz M, Tan E-K, Tayebi N, Toda T, Troiano AR, Tsuji S, Wittstock M, Wolfsberg TG, Wu Y-R, Zabetian CP, Zhao Y, Ziegler SG (2009) Multicenter analysis of glucocerebrosidase mutations in Parkinson's disease. N Engl J Med 361:1651-1661. https://doi.org/10.1056/NEJMoa0901281

Simuni T, Fiske B, Merchant K, Coffey CS, Klingner E, Caspell-Garcia C, Lafontant D-E, Matthews H, Wyse RK, Brundin P, Simon DK, Schwarzschild M, Weiner D, Adams J, Venuto C, Dawson TM, 
Baker L, Kostrzebski M, Ward T, Rafaloff G, Parkinson Study Group NILO-PD Investigators and Collaborators (2021) Efficacy of nilotinib in patients with moderately advanced parkinson disease: a randomized clinical trial. JAMA Neurol 78:312-320. https://doi.org/10.1001/jamaneurol.2020.4725

Smith WW, Liu Z, Liang Y, Masuda N, Swing DA, Jenkins NA, Copeland NG, Troncoso JC, Pletnikov M, Dawson TM, Martin LJ, Moran TH, Lee MK, Borchelt DR, Ross CA (2010) Synphilin-1 attenuates neuronal degeneration in the A53T alpha-synuclein transgenic mouse model. Hum Mol Genet 19:2087-2098. https:// doi.org/10.1093/hmg/ddq086

Snyder SW, Ladror US, Wade WS, Wang GT, Barrett LW, Matayoshi ED, Huffaker HJ, Krafft GA, Holzman TF (1994) Amyloid-beta aggregation: selective inhibition of aggregation in mixtures of amyloid with different chain lengths. Biophys J 67:1216-1228. https://doi.org/10.1016/S0006-3495(94)80591-0

Soligo D, Servida F, Delia D, Fontanella E, Lamorte G, Caneva L, Fumiatti R, Lambertenghi Deliliers G (2001) The apoptogenic response of human myeloid leukaemia cell lines and of normal and malignant haematopoietic progenitor cells to the proteasome inhibitor PSI. Br J Haematol 113:126-135. https://doi.org/10. 1046/j.1365-2141.2001.02683.x

Song S, Lee H, Kam T-I, Tai ML, Lee J-Y, Noh J-Y, Shim SM, Seo SJ, Kong Y-Y, Nakagawa T, Chung C-W, Choi D-Y, Oubrahim H, Jung Y-K (2008) E2-25K/Hip-2 regulates caspase-12 in ER stress-mediated Abeta neurotoxicity. J Cell Biol 182:675-684. https://doi.org/10.1083/jcb.200711066

Spilman P, Podlutskaya N, Hart MJ, Debnath J, Gorostiza O, Bredesen D, Richardson A, Strong R, Galvan V (2010) Inhibition of mTOR by rapamycin abolishes cognitive deficits and reduces amyloidbeta levels in a mouse model of Alzheimer's disease. PLoS ONE 5:e9979. https://doi.org/10.1371/journal.pone.0009979

Su X, Wang L, Song Y, Bai C (2004) Inhibition of inflammatory responses by ambroxol, a mucolytic agent, in a murine model of acute lung injury induced by lipopolysaccharide. Intensive Care Med 30:133-140. https://doi.org/10.1007/s00134-003-2001-y

Sun Q, Wei L-L, Zhang M, Li T-X, Yang C, Deng S-P, Zeng Q-C (2019) Rapamycin inhibits activation of AMPK-mTOR signaling pathway-induced Alzheimer's disease lesion in hippocampus of rats with type 2 diabetes mellitus. Int J Neurosci 129:179-188. https://doi.org/10.1080/00207454.2018.1491571

Suzuki H, Osawa T, Fujioka Y, Noda NN (2017) Structural biology of the core autophagy machinery. Curr Opin Struct Biol Theory Simul Macromol Assem 43:10-17. https://doi.org/10.1016/j.sbi. 2016.09.010

Takahashi Y, He H, Tang Z, Hattori T, Liu Y, Young MM, Serfass JM, Chen L, Gebru M, Chen C, Wills CA, Atkinson JM, Chen H, Abraham T, Wang H-G (2018) An autophagy assay reveals the ESCRT-III component CHMP2A as a regulator of phagophore closure. Nat Commun 9:2855. https://doi.org/10.1038/ s41467-018-05254-w

Takeda A, Mallory M, Sundsmo M, Honer W, Hansen L, Masliah E (1998) Abnormal accumulation of NACP/alpha-synuclein in neurodegenerative disorders. Am J Pathol 152:367-372

Takeuchi S, Fujiwara N, Ido A, Oono M, Takeuchi Y, Tateno M, Suzuki K, Takahashi R, Tooyama I, Taniguchi N, Julien J-P, Urushitani $M$ (2010) Induction of protective immunity by vaccination with wild-type apo superoxide dismutase 1 in mutant SOD1 transgenic mice. J Neuropathol Exp Neurol 69:1044-1056. https:// doi.org/10.1097/NEN.0b013e3181f4a90a

Tanaka A, Cleland MM, Xu S, Narendra DP, Suen D-F, Karbowski M, Youle RJ (2010) Proteasome and p97 mediate mitophagy and degradation of mitofusins induced by Parkin. J Cell Biol 191:1367-1380. https://doi.org/10.1083/jcb.201007013

Taniguchi S, Suzuki N, Masuda M, Hisanaga S, Iwatsubo T, Goedert M, Hasegawa M (2005) Inhibition of heparin-induced tau filament formation by phenothiazines, polyphenols, and porphyrins. J Biol Chem 280:7614-7623. https://doi.org/10.1074/jbc. M408714200

Tasdemir E, Maiuri MC, Tajeddine N, Vitale I, Criollo A, Vicencio JM, Hickman JA, Geneste O, Kroemer G (2007) Cell cycle-dependent induction of autophagy, mitophagy and reticulophagy. Cell Cycle 6:2263-2267. https://doi.org/10.4161/cc.6.18.4681

Tasdemir E, Maiuri MC, Galluzzi L, Vitale I, Djavaheri-Mergny M, D’Amelio M, Criollo A, Morselli E, Zhu C, Harper F, Nannmark U, Samara C, Pinton P, Vicencio JM, Carnuccio R, Moll UM, Madeo F, Paterlini-Brechot P, Rizzuto R, Szabadkai G, Pierron G, Blomgren K, Tavernarakis N, Codogno P, Cecconi F, Kroemer G (2008) Regulation of autophagy by cytoplasmic p53. Nat Cell Biol 10:676-687. https://doi.org/10.1038/ncb1730

Tavassoly O, Safavi F, Tavassoly I (2020) Seeding brain protein aggregation by SARS-CoV-2 as a possible long-term complication of COVID-19 infection. ACS Chem Neurosci 11:3704-3706. https://doi.org/10.1021/acschemneuro.0c00676

Teicher BA, Ara G, Herbst R, Palombella VJ, Adams J (1999) The proteasome inhibitor PS-341 in cancer therapy. Clin Cancer Res $5: 2638-2645$

Torres-López L, Maycotte P, Liñán-Rico A, Liñán-Rico L, Donis-Maturano L, Delgado-Enciso I, Meza-Robles C, Vásquez-Jiménez C, Hernández-Cruz A, Dobrovinskaya O (2019) Tamoxifen induces toxicity, causes autophagy, and partially reverses dexamethasone resistance in Jurkat T cells. J Leukoc Biol 105:983-998. https:// doi.org/10.1002/JLB.2VMA0818-328R

Towers CG, Wodetzki D, Thorburn A (2020) Autophagy and cancer: modulation of cell death pathways and cancer cell adaptations. J Cell Biol. https://doi.org/10.1083/jcb.201909033

Treon SP, Hunter ZR, Matous J, Joyce RM, Mannion B, Advani R, Cook D, Songer J, Hill J, Kaden BR, Sharon D, Steiss R, Leleu X, Branagan AR, Badros A (2007) Multicenter clinical trial of bortezomib in relapsed/refractory Waldenstrom's macroglobulinemia: results of WMCTG Trial 03-248. Clin Cancer Res 13:3320-3325. https://doi.org/10.1158/1078-0432.ccr-06-2511

Tschurtschenthaler M, Adolph TE, Ashcroft JW, Niederreiter L, Bharti R, Saveljeva S, Bhattacharyya J, Flak MB, Shih DQ, Fuhler GM, Parkes M, Kohno K, Iwawaki T, Janneke van der Woude C, Harding HP, Smith AM, Peppelenbosch MP, Targan SR, Ron D, Rosenstiel P, Blumberg RS, Kaser A (2017) Defective ATG16L1-mediated removal of IRE1 $\alpha$ drives Crohn's disease-like ileitis. J Exp Med 214:401-422. https://doi.org/10. 1084/jem.20160791

Uddin M, Unda BK, Kwan V, Holzapfel NT, White SH, Chalil L, Woodbury-Smith M, Ho KS, Harward E, Murtaza N, Dave B, Pellecchia G, D'Abate L, Nalpathamkalam T, Lamoureux S, Wei J, Speevak M, Stavropoulos J, Hope KJ, Doble BW, Nielsen J, Wassman ER, Scherer SW, Singh KK (2018) OTUD7A regulates neurodevelopmental phenotypes in the 15q13.3 microdeletion syndrome. Am J Hum Genet 102:278295. https://doi.org/10.1016/j.ajhg.2018.01.006

Urushitani M, Kurisu J, Tateno M, Hatakeyama S, Nakayama K-I, Kato S, Takahashi R (2004) CHIP promotes proteasomal degradation of familial ALS-linked mutant SOD1 by ubiquitinating Hsp/Hsc70. J Neurochem 90:231-244. https://doi.org/10. 1111/j.1471-4159.2004.02486.x

Urushitani M, Ezzi SA, Julien J-P (2007) Therapeutic effects of immunization with mutant superoxide dismutase in mice models of amyotrophic lateral sclerosis. Proc Natl Acad Sci U S A 104:2495-2500. https://doi.org/10.1073/pnas.0606201104

Valiente-Gabioud AA, Miotto MC, Chesta ME, Lombardo V, Binolfi A, Fernández CO (2016) Phthalocyanines as Molecular scaffolds to block disease-associated protein aggregation. Acc Chem Res 49:801-808. https://doi.org/10.1021/acs.accounts. 5 b00507 
Velikkakath AKG, Nishimura T, Oita E, Ishihara N, Mizushima N (2012) Mammalian Atg2 proteins are essential for autophagosome formation and important for regulation of size and distribution of lipid droplets. Mol Biol Cell 23:896-909. https://doi.org/ 10.1091/mbc.E11-09-0785

Vilchez D, Boyer L, Morantte I, Lutz M, Merkwirth C, Joyce D, Spencer B, Page L, Masliah E, Berggren WT, Gage FH, Dillin A (2012a) Increased proteasome activity in human embryonic stem cells is regulated by PSMD11. Nature 489:304-308. https://doi. org/10.1038/nature11468

Vilchez D, Morantte I, Liu Z, Douglas PM, Merkwirth C, Rodrigues APC, Manning G, Dillin A (2012b) RPN-6 determines C. elegans longevity under proteotoxic stress conditions. Nature 489:263-268. https://doi.org/10.1038/nature11315

Vilchez D, Saez I, Dillin A (2014) The role of protein clearance mechanisms in organismal ageing and age-related diseases. Nat Commun 5:5659. https://doi.org/10.1038/ncomms6659

Wang J, Maldonado MA (2006) The ubiquitin-proteasome system and its role in inflammatory and autoimmune diseases. Cell Mol Immunol 3:255-261

Wang GY, Rayner SL, Chung R, Shi BY, Liang XJ (2020a) Advances in nanotechnology-based strategies for the treatments of amyotrophic lateral sclerosis. Mater Today Bio 6:100055. https://doi. org/10.1016/j.mtbio.2020.100055

Wang H, Zhang T, Ge X, Chen J, Zhao Y, Fu J (2020b) Parkin overexpression attenuates $\mathrm{A} \beta$-induced mitochondrial dysfunction in HEK293 cells by restoring impaired mitophagy. Life Sci 244:117322. https://doi.org/10.1016/j.lfs.2020.117322

Wang P, Chen X, Wang Y, Jia C, Liu X, Wang Y, Wu H, Cai H, Shen H-M, Le W (2021a) Essential role for autophagy protein VMP1 in maintaining neuronal homeostasis and preventing axonal degeneration. Cell Death Dis 12:116. https://doi.org/10.1038/ s41419-021-03412-5

Wang P, Li Y, Ma Y, Zhang X, Li Z, Yu W, Zhu M, Wang J, Xu $\mathrm{Y}, \mathrm{Xu}$ A (2021b) Comprehensive investigation into the role of ubiquitin-conjugating enzyme E2S in melanoma development. J Investig Dermatol 141:374-384. https://doi.org/10.1016/j.jid. 2020.05.113

Watanabe Y, Taguchi K, Tanaka M (2020) Ubiquitin, autophagy and neurodegenerative diseases. Cells 9:E2022. https://doi.org/10. 3390/cells9092022

Wauer T, Komander D (2013) Structure of the human Parkin ligase domain in an autoinhibited state. EMBO J 32:2099-2112. https:// doi.org/10.1038/emboj.2013.125

Wauer T, Simicek M, Schubert A, Komander D (2015) Mechanism of phospho-ubiquitin-induced PARKIN activation. Nature 524:370374. https://doi.org/10.1038/nature14879

Webb JL, Ravikumar B, Atkins J, Skepper JN, Rubinsztein DC (2003) Alpha-Synuclein is degraded by both autophagy and the proteasome. J Biol Chem 278:25009-25013. https://doi.org/10.1074/ jbc.M300227200

White E (2015) The role for autophagy in cancer. J Clin Invest 125:4246. https://doi.org/10.1172/JCI73941

Whitesell L, Lindquist SL (2005) HSP90 and the chaperoning of cancer. Nat Rev Cancer 5:761-772. https://doi.org/10.1038/nrc1716

Wilcock GK, Gauthier S, Frisoni GB, Jia J, Hardlund JH, Moebius HJ, Bentham P, Kook KA, Schelter BO, Wischik DJ, Davis CS, Staff RT, Vuksanovic V, Ahearn T, Bracoud L, Shamsi K, Marek K, Seibyl J, Riedel G, Storey JMD, Harrington CR, Wischik CM (2018) Potential of low dose leuco-methylthioninium bis(Hydromethanesulphonate) (LMTM) monotherapy for treatment of mild Alzheimer's disease: cohort analysis as modified primary outcome in a phase III clinical trial. J Alzheimer's Dis 61:435-457. https://doi.org/10.3233/JAD-170560
Wilkinson KD (2000) Ubiquitination and deubiquitination: targeting of proteins for degradation by the proteasome. Semin Cell Dev Biol 11:141-148. https://doi.org/10.1006/scdb.2000.0164

Wilson GR, Sim JCH, McLean C, Giannandrea M, Galea CA, Riseley JR, Stephenson SEM, Fitzpatrick E, Haas SA, Pope K, Hogan KJ, Gregg RG, Bromhead CJ, Wargowski DS, Lawrence CH, James PA, Churchyard A, Gao Y, Phelan DG, Gillies G, Salce N, Stanford L, Marsh APL, Mignogna ML, Hayflick SJ, Leventer RJ, Delatycki MB, Mellick GD, Kalscheuer VM, D’Adamo P, Bahlo M, Amor DJ, Lockhart PJ (2014) Mutations in RAB39B cause X-linked intellectual disability and early-onset Parkinson disease with $\alpha$-synuclein pathology. Am J Hum Genet 95:729735. https://doi.org/10.1016/j.ajhg.2014.10.015

Wilson EN, Do Carmo S, Welikovitch LA, Hall H, Aguilar LF, Foret MK, Iulita MF, Jia DT, Marks AR, Allard S, Emmerson JT, Ducatenzeiler A, Cuello AC (2020) NP03, a microdose lithium formulation, blunts early amyloid post-plaque neuropathology in McGill-R-Thy1-APP Alzheimer-like transgenic rats. JAD 73:723-739. https://doi.org/10.3233/JAD-190862

Wischik CM, Edwards PC, Lai RY, Roth M, Harrington CR (1996) Selective inhibition of Alzheimer disease-like tau aggregation by phenothiazines. Proc Natl Acad Sci USA 93:11213-11218. https://doi.org/10.1073/pnas.93.20.11213

Wischik CM, Staff RT, Wischik DJ, Bentham P, Murray AD, Storey JMD, Kook KA, Harrington CR (2015) Tau aggregation inhibitor therapy: an exploratory phase 2 study in mild or moderate Alzheimer's disease. J Alzheimers Dis 44:705-720. https://doi. org/10.3233/JAD-142874

Wu Y, Li X, Zhu JX, Xie W, Le W, Fan Z, Jankovic J, Pan T (2011) Resveratrol-activated AMPK/SIRT1/autophagy in cellular models of Parkinson's disease. NSG 19:163-174. https://doi.org/10. $1159 / 000328516$

Xia X, Huang C, Liao Y, Liu Y, He J, Guo Z, Jiang L, Wang X, Liu J, Huang H (2019) Inhibition of USP14 enhances the sensitivity of breast cancer to enzalutamide. J Exp Clin Cancer Res 38:220. https://doi.org/10.1186/s13046-019-1227-7

Xiao C, Qiu S, Li X, Luo D-J, Liu G-P (2019) EDTP/MTMR14: a novel target for improved survivorship to prolonged anoxia and cellular protein aggregates. Neurosci Lett 705:151-158. https://doi.org/10.1016/j.neulet.2019.04.053

Xilouri M, Vogiatzi T, Vekrellis K, Park D, Stefanis L (2009) Abberant alpha-synuclein confers toxicity to neurons in part through inhibition of chaperone-mediated autophagy. PLoS ONE 4:e5515. https://doi.org/10.1371/journal.pone.0005515

Xu W, Xu J (2018) C9orf72 dipeptide repeats cause selective neurodegeneration and cell-autonomous excitotoxicity in drosophila glutamatergic neurons. J Neurosci 38:7741-7752. https://doi. org/10.1523/JNEUROSCI.0908-18.2018

Xu Q, Langley M, Kanthasamy AG, Reddy MB (2017) Epigallocatechin gallate has a neurorescue effect in a mouse model of parkinson disease. J Nutr 147:1926-1931. https://doi.org/10. 3945/jn.117.255034

Yamaguchi J, Suzuki C, Nanao T, Kakuta S, Ozawa K, Tanida I, Saitoh T, Sunabori T, Komatsu M, Tanaka K, Aoki S, Sakimura K, Uchiyama Y (2018) Atg9a deficiency causes axon-specific lesions including neuronal circuit dysgenesis. Autophagy 14:764-777. https://doi.org/10.1080/15548627.2017.1314897

Yang Y, Nishimura I, Imai Y, Takahashi R, Lu B (2003) Parkin suppresses dopaminergic neuron-selective neurotoxicity induced by Pael-R in drosophila. Neuron 37:911-924. https://doi.org/ 10.1016/S0896-6273(03)00143-0

Yang F, Lim GP, Begum AN, Ubeda OJ, Simmons MR, Ambegaokar SS, Chen PP, Kayed R, Glabe CG, Frautschy SA, Cole GM (2005) Curcumin inhibits formation of amyloid beta oligomers 
and fibrils, binds plaques, and reduces amyloid in vivo. J Biol Chem 280:5892-5901. https://doi.org/10.1074/jbc.M4047 51200

Yang-Hartwich Y, Bingham J, Garofalo F, Alvero AB, Mor G (2015a) Detection of $\mathrm{p} 53$ protein aggregation in cancer cell lines and tumor samples. Methods Mol Biol 1219:75-86. https://doi.org/ 10.1007/978-1-4939-1661-0_7

Yang-Hartwich Y, Soteras MG, Lin ZP, Holmberg J, Sumi N, Craveiro V, Liang M, Romanoff E, Bingham J, Garofalo F, Alvero A, Mor $\mathrm{G}(2015 \mathrm{~b}) \mathrm{p} 53$ protein aggregation promotes platinum resistance in ovarian cancer. Oncogene 34:3605-3616. https://doi.org/10. 1038/onc.2014.296

Yao T, Ndoja A (2012) Regulation of gene expression by the ubiquitinproteasome system. Sem Cell Dev Biol Cell Regul Select Protein Degrad Biol Mammary Gland Dev 23:523-529. https://doi.org/ 10.1016/j.semcdb.2012.02.006

Yap TL, Gruschus JM, Velayati A, Westbroek W, Goldin E, Moaven N, Sidransky E, Lee JC (2011) $\alpha$-synuclein interacts with glucocerebrosidase providing a molecular link between Parkinson and Gaucher diseases *. J Biol Chem 286:28080-28088. https:// doi.org/10.1074/jbc.M111.237859

Yau RG, Doerner K, Castellanos ER, Haakonsen DL, Werner A, Wang N, Yang XW, Martinez-Martin N, Matsumoto ML, Dixit VM, Rape M (2017) Assembly and function of heterotypic ubiquitin chains in cell cycle and protein quality control. Cell 171:918-933. e20. https://doi.org/10.1016/j.cell.2017.09.040

Yin H, Wu H, Chen Y, Zhang J, Zheng M, Chen G, Li L, Lu Q (2018) The therapeutic and pathogenic role of autophagy in autoimmune diseases. Front Immunol 9:1512. https://doi.org/10.3389/fimmu. 2018.01512

Yong Y, Ding H, Fan Z, Luo J, Ke Z-J (2011) Lithium fails to protect dopaminergic neurons in the 6-OHDA model of Parkinson's disease. Neurochem Res 36:367-374. https://doi.org/10.1007/ s11064-010-0368-z

Youle RJ, Narendra DP (2011) Mechanisms of mitophagy. Nat Rev Mol Cell Biol 12:9-14. https://doi.org/10.1038/nrm3028

Yu K, Toral-Barza L, Discafani C, Zhang WG, Skotnicki J, Frost P, Gibbons JJ (2001) mTOR, a novel target in breast cancer: the effect of CCI-779, an mTOR inhibitor, in preclinical models of breast cancer. Endocr Relat Cancer 8:249-258

Yu H-C, Lin C-S, Tai W-T, Liu C-Y, Shiau C-W, Chen K-F (2013) Nilotinib induces autophagy in hepatocellular carcinoma through ampk activation. J Biol Chem 288:18249-18259. https://doi.org/ 10.1074/jbc.M112.446385

Yun CW, Lee SH (2018) The roles of autophagy in cancer. Int J Mol Sci. https://doi.org/10.3390/ijms19113466

Yung C, Sha D, Li L, Chin L-S (2016) Parkin protects against misfolded SOD1 toxicity by promoting its aggresome formation and autophagic clearance. Mol Neurobiol 53:6270-6287. https://doi. org/10.1007/s12035-015-9537-z

Yushchenko T, Deuerling E, Hauser K (2018) Insights into the aggregation mechanism of PolyQ proteins with different glutamine repeat lengths. Biophys J 114:1847-1857. https://doi.org/10.1016/j.bpj. 2018.02.037

Zeng F, Ma X, Zhu L, Xu Q, Zeng Y, Gao Y, Li G, Guo T, Zhang H, Tang X, Wang Z, Ye Z, Zheng L, Zhang H, Zheng Q, Li K, Lu J, Qi X, Luo H, Zhang X, Wang Z, Zhou Y, Yao Y, Ke R, Zhou Y, Liu Y, Sun H, Huang T, Shao Z, Xu H, Wang X (2019) The deubiquitinase USP6 affects memory and synaptic plasticity through modulating NMDA receptor stability. PLoS Biol 17:e3000525. https://doi.org/10.1371/journal.pbio.3000525

Zhang W-G, Yu J-P, Wu Q-M, Tong Q, Li S-B, Wang X-H, Xie G-J (2004) Inhibitory effect of ubiquitin-proteasome pathway on proliferation of esophageal carcinoma cells. World J Gastroenterol 10:2779-2784. https://doi.org/10.3748/wjg.v10.i19.2779
Zhang X, Li F, Bulloj A, Zhang Y-W, Tong G, Zhang Z, Liao F-F, Xu H (2006a) Tumor-suppressor PTEN affects tau phosphorylation, aggregation, and binding to microtubules. FASEB J 20:12721274. https://doi.org/10.1096/fj.06-5721fje

Zhang X, Zhang Y, Liu S, Bulloj A, Tong GG, Zhang Z, Liao F-F, Xu $\mathrm{H}$ (2006b) Tumor suppressor PTEN affects tau phosphorylation: deficiency in the phosphatase activity of PTEN increases aggregation of an FTDP-17 mutant Tau. Mol Neurodegeneration 1:7. https://doi.org/10.1186/1750-1326-1-7

Zhang X, Li L, Chen S, Yang D, Wang Y, Zhang X, Wang Z, Le W (2011) Rapamycin treatment augments motor neuron degeneration in SOD1G93A mouse model of amyotrophic lateral sclerosis. Autophagy 7:412-425. https://doi.org/10.4161/auto.7.4. 14541

Zhang X, Linder S, Bazzaro M (2020) Drug development targeting the ubiquitin-proteasome system (UPS) for the treatment of human cancers. Cancers (basel). https://doi.org/10.3390/cancers120 40902

Zhang S, Shao Z, Liu X, Hou M, Cheng F, Lei D, Yuan H (2021a) The E50K optineurin mutation impacts autophagy-mediated degradation of TDP-43 and leads to RGC apoptosis in vivo and in vitro. Cell Death Discov 7:1-13. https://doi.org/10.1038/ s41420-021-00432-0

Zhang X, Zhang X, Li Y, Zhong M, Zhao P, Guo C, Xu H, Wang $\mathrm{T}$, Gao H (2021b) Brain targeting and $\mathrm{A} \beta$ binding bifunctional nanoparticles inhibit amyloid protein aggregation in APP/PS1 Transgenic mice. ACS Chem Neurosci 12:2110-2121. https:// doi.org/10.1021/acschemneuro.1c00035

Zhang Y, Sun H, Pei R, Mao B, Zhao Z, Li H, Lin Y, Lu K (2021c) The SARS-CoV-2 protein ORF3a inhibits fusion of autophagosomes with lysosomes. Cell Discov 7:31. https://doi.org/10.1038/ s41421-021-00268-z

Zhao W, Beers DR, Bell S, Wang J, Wen S, Baloh RH, Appel SH (2015) TDP-43 activates microglia through NF- $\mathrm{KB}$ and NLRP3 inflammasome. Exp Neurol 273:24-35. https://doi.org/10.1016/j. expneurol.2015.07.019

Zhao S, Xia J, Wu X, Zhang L, Wang P, Wang H, Li H, Wang X, Chen Y, Agnetti J, Li Y, Pei D, Shu X (2018) Deficiency in class III PI3-kinase confers postnatal lethality with IBD-like features in zebrafish. Nat Commun 9:2639. https://doi.org/10.1038/ s41467-018-05105-8

Zhao B, Marciniuk K, Gibbs E, Yousefi M, Napper S, Cashman NR (2019) Therapeutic vaccines for amyotrophic lateral sclerosis directed against disease specific epitopes of superoxide dismutase 1. Vaccine 37:4920-4927. https://doi.org/10.1016/j.vacci ne.2019.07.044

Zhao L, Zhao J, Zhang Y, Wang L, Zuo L, Niu A, Zhang W, Xue X, Zhao S, Sun C, Li K, Wang J, Bian Z, Zhao X, Saur D, Seidler B, Wang C, Qi T (2021) Generation and identification of a conditional knockout allele for the PSMD11 gene in mice. BMC Dev Biol 21:4. https://doi.org/10.1186/s12861-020-00233-1

Zhou X-J, Verginis P, Martinez J, Radic M (2019) Editorial: autophagy in autoimmunity. Front Immunol 10:301. https://doi.org/10.3389/ fimmu.2019.00301

Zucchelli S, Codrich M, Marcuzzi F, Pinto M, Vilotti S, Biagioli M, Ferrer I, Gustincich S (2010) TRAF6 promotes atypical ubiquitination of mutant DJ-1 and alpha-synuclein and is localized to Lewy bodies in sporadic Parkinson's disease brains. Hum Mol Genet 19:3759-3770. https://doi.org/10.1093/hmg/ddq290

Publisher's Note Springer Nature remains neutral with regard to jurisdictional claims in published maps and institutional affiliations. 